NIST Technical Note 1925

\title{
Simulation of Residential Carbon Monoxide Exposure Due to Generator Operation in Enclosed Spaces
}

\author{
Steven J. Emmerich \\ Brian Polidoro \\ W. Stuart Dols
}

This publication is available free of charge from:

http://dx.doi.org/10.6028/NIST.TN.1925 Standards and Technology U.S. Department of Commerce 


\title{
Simulation of Residential Carbon Monoxide Exposure Due to Generator Operation in Enclosed Spaces
}

\author{
Steven J. Emmerich \\ Brian Polidoro \\ W. Stuart Dols \\ Energy and Environment Division \\ Engineering Laboratory
}

This publication is available free of charge from:

http://dx.doi.org/10.6028/NIST.TN.1925

September 2016

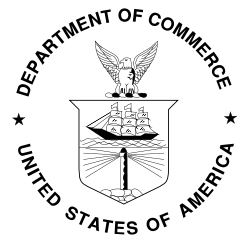

U.S. Department of Commerce

Penny Pritzker, Secretary 
Certain commercial entities, equipment, or materials may be identified in this document in order to describe an experimental procedure or concept adequately. Such identification is not intended to imply recommendation or endorsement by the National Institute of Standards and Technology, nor is it intended to imply that the entities, materials, or equipment are necessarily the best available for the purpose.

National Institute of Standards and Technology Technical Note 1925 Natl. Inst. Stand. Technol. Tech. Note 1925, 49 pages (September 2016) CODEN: NTNOEF

This publication is available free of charge from: http://dx.doi.org/10.6028/NIST.TN.1925 


\begin{abstract}
The U.S. Consumer Product Safety Commission (CPSC) and others are concerned about the hazard of acute carbon monoxide $(\mathrm{CO})$ exposures from portable gasoline powered generators that can result in death or serious adverse health effects in exposed individuals. As of May 15, 2015, the CPSC databases contain records of at least 702 deaths (involving 523 incidents) from CO poisoning in the U.S. caused by consumer use of a generator in the period of 2004 through 2014 (Hnatov 2015). There were an additional 49 CO poisoning deaths (involving 39 incidents) associated with consumer use of both a generator and at least one other $\mathrm{CO}$-producing consumer appliance, for a total of $751 \mathrm{CO}$ poisoning deaths (involving 562 incidents) associated with generators for the same 11-year period. The majority of these deaths occurred when consumers used a generator in an enclosed or partially enclosed space or outdoors near an open door, window or vent. While avoiding the operation of such generators in or near an enclosed space is expected to reduce indoor $\mathrm{CO}$ exposures significantly, it may not be realistic to expect such usage to be eliminated completely. Another means of reducing these exposures would be to decrease the rate at which $\mathrm{CO}$ is emitted from these devices. A computer simulation study was conducted to provide CPSC staff with information to support comparisons of modeled residential $\mathrm{CO}$ exposures reflecting operation of current designs of portable engine-driven electric generators, inside homes or in attached garages. These results were compared to simulated operation of reduced emission generators meeting a potential $\mathrm{CO}$ emission rate limit performance requirement being considered by CPSC staff under portable generator rulemaking activities. These simulations employed the multizone airflow and contaminant transport model CONTAM, which was applied to a set of 40 buildings (consisting of 37 houses and 3 detached garages, considered broadly representative of fatal CO poisoning incidents reported in CPSC databases) that are primarily based on a collection of models representative of the U.S. housing stock. This report presents sample CO and carboxyhemoglobin $(\mathrm{COHb})$ simulation results for three of the houses and one of the garages modeled. The results presented demonstrate that generators with the reduced $\mathrm{CO}$ emission rates result in peak $\mathrm{CO}$ concentrations that can be reduced by $40 \%$ to more than $90 \%$ depending on the specific case being analyzed. The reduced $\mathrm{CO}$ emission rates also result in significant reductions in $\mathrm{COHb}$ in many cases. Additionally, use of a thermal building model coupled with the airflow and IAQ model to properly account for thermal effects was shown to be important as the interaction of the generator's heat generation and the ambient weather conditions can significantly impact both air change rates and interzone airflow patterns in the buildings.
\end{abstract}

KEYWORDS: carbon monoxide; CONTAM; emergency generators; multizone airflow model; simulation 


\section{TABLE OF CONTENTS}

1. INTRODUCTION 1

2. ANALYSIS METHOD 3

2.1 Modeling approach 3

2.2 Baseline house models

2.2.1 Description of homes 4

$\begin{array}{ll}\text { 2.2.2 Source locations and emission rates } & 7\end{array}$

2.3 Simulation cases and output analysis $\quad 8$

$\begin{array}{ll}2.4 \mathrm{COHb} \text { time profile calculation } & 8\end{array}$

3. RESULTS 9

3.1 Sample results for a small manufactured house (MH1mod) 9

3.2 Sample results for a mid-sized detached house with basement and integral garage (DH-45mod) 19

3.3 Sample results for a large 2-story detached house with garage (DH-12) 26

3.4 Sample results for a large garage with workshop (GAR3) 33

4. SUMMARY AND DISCUSSION 36

5. ACKNOWLEDGEMENTS 37

$\begin{array}{ll}\text { 6. REFERENCES } & 37\end{array}$

APPENDICES
A. House Characteristics

B. Source Locations and Modifications for Each Building 46

C. Analysis of Gen X CO Emission Ratio at Reduced $\mathrm{O}_{2}$ vs Ambient 49 


\section{INTRODUCTION}

The U.S. Consumer Product Safety Commission (CPSC) and others are concerned about the hazard of acute carbon monoxide (CO) exposures from portable gasoline powered generators that can result in death or serious adverse health effects in exposed individuals. As of May 15, 2015, the CPSC databases contain records of at least 702 deaths (involving 523 incidents) from CO poisoning caused by consumer use of a generator in the period of 2004 through 2014 (Hnatov 2015). There were an additional 49 CO poisoning deaths (involving 39 incidents) associated with consumer use of both a generator and at least one other CO-producing consumer appliance, for a total of $751 \mathrm{CO}$ poisoning deaths (involving 562 incidents) associated with generators for the same 11-year period. The majority of these deaths occurred when consumers used a generator in an enclosed or partially enclosed space or outdoors near an open door, window or vent. While avoiding the operation of such generators in or near an enclosed space is expected to reduce indoor CO exposures significantly, it may not be realistic to expect such usage to be eliminated completely.

Another means of reducing these exposures would be to decrease the rate at which CO is emitted from these devices. The magnitude of such reductions needed to reduce exposures to some specific level depends on the complex relationship between $\mathrm{CO}$ emissions from these generators and multiple factors influencing occupant exposure. Technically achievable levels of CO emissions reduction have been studied by NIST through an experimental investigation of CO emissions from generators in a shed and in a house. These investigations included measurements on prototype generators that were modified to reduce their CO emission rates (Emmerich et al. 2013). That study has provided a set of unique measurements of CO emission rates for both unmodified and modified generators.

The issue of how $\mathrm{CO}$ emission rates relate to occupant exposure and health impacts involves the interaction between generator operation, house characteristics, weather conditions, occupant activity, and health status. National Institute of Standards and Technology (NIST) Technical Note 1782 (Persily et al. 2013) described a computer simulation study conducted to evaluate indoor CO exposures as a function of generator source location and $\mathrm{CO}$ emission rate to support life-safety based analyses of potential CO emission limits. Those simulations employed the multizone airflow and contaminant transport model CONTAM (the most recent available version is described in detail by Dols and Polidoro 2015), which was applied to a collection of 83 single-family, detached dwellings and 4 manufactured homes that are representative of the U.S. housing stock for these housing types. All house heating, ventilating and air-conditioning (HVAC) systems were modeled as "off" in the simulations based on not having electric power during an outage. The project described in this report extended and modified the methods used in the previous work. This new work will support CPSC staff efforts to make, for a range of generator sizes, more accurate comparisons between likely CO exposures throughout homes resulting from operation of current portable engine-driven electric generators in residences and attached garages, as well as exposures from generators with low $\mathrm{CO}$ emissions that meet a technical feasibility-based performance requirement that CPSC staff is considering under its portable generator rulemaking activity. 
Specific extensions and modification in this effort relative to the previous CO modeling study described in Technical Note 1782 include:

- accounting for temperature distributions within the simulated houses, accounting for ambient weather conditions and the heat released by the generator, using a version of the CONTAM model with heat transfer modeling capability;

- consideration of generator size-dependent CO emission rates;

- use of constant CO emission rates, independent of the source location $\mathrm{O}_{2}$ level, for modeling generators meeting the potential performance requirements;

- use of generator size-dependent run times;

- calculation of percent carboxyhemoglobin $(\mathrm{COHb})$ profiles for generic adult occupants in individual rooms using more refined, short term inhalation rates (respiratory minute volumes (RMV)) characteristic of indoor activities over 24 hours;

- modeling a subset of the 87 homes included in the previous study, including some modifications to the floorplans;

- modeling 3 additional buildings to represent various sizes and styles of detached garages; and

- reporting modeling results of all rooms, including unconditioned spaces such as basements and garages.

A total of over 45 thousand individual 24-hour simulations were conducted. This report presents detailed $\mathrm{CO}$ and $\mathrm{COHb}$ simulation results for three of the houses and one of the detached garages. 


\section{ANALYSIS METHOD}

This simulation study was conducted to evaluate indoor $\mathrm{CO}$ exposures as a function of generator source location and CO emission rate in order to support cost-benefit analyses of potential CO emission limits for generators. These simulations employed the multizone airflow and contaminant transport model CONTAM, which was applied to 40 buildings including 37 versions of dwellings drawn from a collection that are representative of the U.S. housing stock (Persily et al. 2006) and three new garage buildings. These buildings were identified as broadly representative of fatal generator-related CO poisoning incidents reported in CPSC databases. A total of over 45 thousand individual 24-hour simulations were conducted that cover a range of house layouts and sizes, airtightness levels and weather conditions, as well as generator locations, $\mathrm{CO}$ source strengths and operating schedules. The locations include attached garages, crawlspaces and basements, in the houses that have such spaces, and two interior rooms in all of the houses considered. This section describes the approach used to perform the simulations, including the simulation program, the houses, the simulated generator locations and associated CO emission rates, and the manner in which the simulations were performed and the output analyzed.

\subsection{Modeling approach}

Using these homes (described below), indoor CO concentrations were calculated using the multizone airflow and contaminant transport model CONTAM (Dols and Polidoro 2015) over a range of source (generator) locations, CO emission rates, and weather conditions. As described below, these simulations yielded CO concentrations in the rooms of each house as a function of time during the 24-hour analysis interval, which included a scheduled period of CO emissions from generator operation followed by a period with no CO emissions. These concentrations were then used to calculate $\mathrm{COHb}$ values for an occupant spending the full 24 hours in each occupiable zone. This section describes the manner in which these simulations were conducted and the results analyzed.

CONTAM is a simulation tool for predicting airflows and contaminant concentrations in multizone building airflow systems. When using CONTAM, a building is represented as a series of interconnected zones (e.g. rooms), with the airflow paths (e.g., leakage sites, open doors) between the zones and the outdoors defined as mathematical relationships between the airflow through the path and the pressure difference across it. Outdoor weather conditions are also input into CONTAM, as they are key determinants of pressure differences across airflow paths in exterior walls. System airflow rates must also be defined to capture their effects on building and interzone pressure differences. These inputs are used to define mass balances of air into and out of each zone, which are solved simultaneously to determine the interzone pressure relationships and resulting airflow rates between each zone, including the outdoors. These airflow rates can be calculated over time as weather conditions and system airflow rates change. Once the airflows are established, CONTAM can then calculate contaminant concentrations over time in each building zone based on contaminant source characteristics and contaminant removal information, such as that associated with filtration. CONTAM has been used for several decades, and a range of validation studies have demonstrated its ability to reliably predict building air change rates and contaminant levels (Emmerich 2001, Emmerich et al. 2004, Poppendieck et al. 2016). Emmerich 
and Dols (2015) report a validation study that specifically evaluated the model's capability to predict $\mathrm{CO}$ concentrations in a test house from portable generator operation in an attached garage.

\section{2 Baseline house models}

\subsubsection{Description of homes}

The house models used in the simulations are based on a collection of dwellings that were previously defined by Persily et al. (2006), which includes just over 200 dwellings that together represented $80 \%$ of the U.S. housing stock. Those dwellings are grouped into four categories: detached (83 homes), attached (53 homes), manufactured (4 homes) and apartments (69). The definition of that set of dwellings was based on the following variables using the US Census Bureau's American Housing Survey (AHS) (HUD 1999) and the US Department of Energy's (DOE) Residential Energy Consumption Survey (RECS) (DOE 2005): housing type, number of stories, heated floor area, year built, foundation type, presence of a garage, type of heating equipment, number of bedrooms, number of bathrooms, and number of other rooms. Appendix A summarizes the characteristics of these dwellings and identifies the corresponding CONTAM project file name and associated floor plan. In addition to defining the dwellings, multizone representations were created in the airflow and contaminant transport model CONTAM to support their use in analyzing a range of ventilation and indoor air quality issues. The project files and floor plans can be downloaded at the CONTAM website www.bfrl.nist.gov/IAQanalysis under Case Studies. However, as discussed below, these files were modified for the purposes of this analysis.

Based on the CPSC analysis of CO poisoning death incidents from 2004 through 2012 (Hnatov 2015), a subset of the NIST suite of homes collection described above (in some cases with modifications) were used for this analysis, and includes 31 detached house (DH) models, 4 attached house ( $\mathrm{AH}$ ) models, and 2 manufactured house $(\mathrm{MH})$ models. The modifications made to the models are described in Appendix B. Additionally, 3 new detached garage (GAR) buildings were defined and modeled including 2 single-zone garage/sheds ( 1 car size and 2 car size) and 1 larger garage/shed with a separate work space inside. None of the apartment models were employed due to the challenge in accounting for airflow between units and the lack of air leakage data for the partitions between units.

Air handling system operation: While the homes in the NIST suite of homes collection include air handling systems for heating and cooling, this analysis was based on the assumption that the forced-air distribution systems were not operating due to a power outage. This is consistent with the CPSC analysis of the CO incident database, which does not include incidents where the generator was used to operate the central HVAC system. Similarly, all local exhaust fans (kitchen and bath) were also assumed to be off.

Weather conditions and wind exposure: Each house and generator source combination was analyzed for 28 individual days. Each of the 28 simulations employed a different day of weather conditions, including outdoor temperature, wind speed and wind direction, that varied each day on 
an hourly basis. These 28 days of weather (used in the previous study) correspond to two weeks of cold weather (due to the observed frequency of events during the winter season), one week of warm and one week of mild. The hourly weather data for these three conditions were a subset of typical weather files for the following three cities: Detroit MI (cold), Miami FL (warm) and Columbus $\mathrm{OH}$ (mild). Table 1 presents a summary of the weather conditions for the 28 days in the form of daily average, minimum and maximum outdoor temperatures and wind speeds.

Table 1 Summary of Hourly Weather Data Used in Simulations

\begin{tabular}{|c|c|c|c|c|c|c|}
\hline \multirow[t]{2}{*}{ Day } & \multicolumn{3}{|c|}{ Outdoor temperature, ${ }^{\circ} \mathrm{C}\left({ }^{\circ} \mathbf{F}\right)$} & \multicolumn{3}{|c|}{ Wind speed, m/s (mph) } \\
\hline & Average & Minimum & Maximum & Average & Minimum & Maximum \\
\hline 1-Jan & 0.7 (33.3) & $-1.7(28.9)$ & $5.6(42.1)$ & $3.2(7.2)$ & $0.0(0.0)$ & 5.7 (12.8) \\
\hline 2-Jan & $6.1(43.1)$ & $0.0(32.0)$ & $12.2(54.0)$ & $3.9(8.8)$ & $2.1(4.7)$ & $5.7(12.8)$ \\
\hline 3-Jan & $2.5(36.6)$ & $1.1(34.0)$ & $4.4(39.9)$ & $3.1(6.8)$ & $2.1(4.7)$ & $4.1(9.2)$ \\
\hline 4-Jan & 0.9 (33.6) & $0.0(32.0)$ & $1.7(35.1)$ & $2.9(6.6)$ & $0.0(0.0)$ & $4.6(10.3)$ \\
\hline 5-Jan & $-2.9(26.8)$ & $-5.0(23.0)$ & $0.0(32.0)$ & $5.8(13.1)$ & $4.1(9.2)$ & 8.2 (18.3) \\
\hline 6-Jan & $-3.3(26.1)$ & $-5.0(23.0)$ & $-1.7(28.9)$ & $5.2(11.6)$ & $1.5(3.4)$ & 8.2 (18.3) \\
\hline 7-Jan & $-3.8(25.2)$ & $-6.1(21.0)$ & $-2.2(28.0)$ & $3.2(7.2)$ & $0.0(0.0)$ & $5.2(11.6)$ \\
\hline 8-Jan & $-1.7(28.9)$ & $-3.3(26.1)$ & $0.0(32.0)$ & $2.4(5.3)$ & $0.0(0.0)$ & $5.2(11.6)$ \\
\hline 9-Jan & $-0.1(31.8)$ & $-1.7(28.9)$ & $1.1(34.0)$ & $3.5(7.7)$ & $1.5(3.4)$ & 6.2 (13.9) \\
\hline 10-Jan & 1.8 (35.3) & $1.0(33.8)$ & $2.8(37.0)$ & $3.5(7.7)$ & $0.0(0.0)$ & $6.7(15.0)$ \\
\hline 11-Jan & $0.6(33.0)$ & $-0.6(30.9)$ & $1.1(34.0)$ & $4.3(9.5)$ & $0.0(0.0)$ & 5.7 (12.8) \\
\hline 12-Jan & $4.9(40.7)$ & $0.6(33.1)$ & $13.3(55.9)$ & $3.9(8.7)$ & $0.0(0.0)$ & 8.8 (19.7) \\
\hline 13-Jan & $9.2(48.5)$ & $0.6(33.1)$ & $14.4(57.9)$ & $6.4(14.3)$ & $2.6(5.8)$ & $10.3(23.0)$ \\
\hline 14-Jan & $-5.5(22.2)$ & $-9.4(15.1)$ & $1.1(34.0)$ & $5.3(11.9)$ & $2.6(5.8)$ & $7.2(16.1)$ \\
\hline 3-Apr & $6.0(42.7)$ & $2.8(37.0)$ & $8.3(46.9)$ & $6.9(15.5)$ & $0.0(0.0)$ & $9.8(21.9)$ \\
\hline 4-Apr & $6.3(43.3)$ & $-0.6(30.9)$ & $13.3(55.9)$ & $2.1(4.7)$ & $0.0(0.0)$ & $5.7(12.8)$ \\
\hline 5-Apr & $9.0(48.1)$ & $1.1(34.0)$ & $15.6(60.1)$ & $1.8(4.0)$ & $0.0(0.0)$ & $3.6(8.1)$ \\
\hline 6-Apr & $11.9(53.4)$ & $5.0(41.0)$ & $18.9(66.0)$ & $3.7(8.3)$ & $2.1(4.7)$ & 6.2 (13.9) \\
\hline 7-Apr & $16.2(61.1)$ & $11.1(52.0)$ & $22.8(73.0)$ & $5.4(12.1)$ & $0.0(0.0)$ & $12.4(27.7)$ \\
\hline 8-Apr & $11.0(51.8)$ & $7.0(44.6)$ & $13.9(57.0)$ & $6.0(13.5)$ & $0.0(0.0)$ & $9.8(21.9)$ \\
\hline 9-Apr & 8.5 (47.3) & $3.9(39.0)$ & $13.3(55.9)$ & $5.5(12.4)$ & $0.0(0.0)$ & 8.2 (18.3) \\
\hline 25-Jul & $28.5(83.2)$ & $25.6(78.1)$ & 33.3 (91.9) & $2.5(5.7)$ & $1.0(2.2)$ & $5.2(11.6)$ \\
\hline 26-Jul & $29.3(84.8)$ & $25.0(77.0)$ & $35.0(95.0)$ & $3.4(7.6)$ & $1.5(3.4)$ & $7.2(16.1)$ \\
\hline 27-Jul & $29.5(85.2)$ & $25.0(77.0)$ & $35.0(95.0)$ & $2.5(5.7)$ & $1.5(3.4)$ & $6.2(13.9)$ \\
\hline 28-Jul & $30.0(86.1)$ & $25.6(78.1)$ & $35.6(96.1)$ & $3.0(6.7)$ & $1.0(2.2)$ & $5.2(11.6)$ \\
\hline 29-Jul & 28.5 (83.3) & $25.6(78.1)$ & $33.9(93.0)$ & $3.3(7.3)$ & $1.0(2.2)$ & $11.3(25.3)$ \\
\hline 30-Jul & $29.2(84.5)$ & $26.1(79.0)$ & 33.3 (91.9) & $3.0(6.7)$ & $1.0(2.2)$ & $6.2(13.9)$ \\
\hline 31-Jul & 29.0 (84.1) & $27.8(82.0)$ & 31.7 (89.1) & $4.3(9.6)$ & $0.0(0.0)$ & 8.2 (18.3) \\
\hline
\end{tabular}

A CONTAM model of a building is associated with a terrain shielding coefficient to account for the impacts of surrounding terrain, buildings and vegetation on surface-averaged, wind-induced pressures on the exterior façade of the building. CONTAM specifies three categories of terrain for 
flat exposed areas (e.g., airport), suburban, and dense urban centers, and a user can input coefficients to capture a range of terrain options in between the flat and urban extremes. These simulations employed the suburban category of terrain shielding, which corresponds to areas with obstructions of the size and spacing of single-family homes. The houses were oriented such that the predominant wind direction for the simulated weather conditions was directed toward the garage door for houses with garages or toward the front of the house for houses without garages.

Indoor air temperatures: In Persily et al. (2013), the indoor temperature was held constant at $23{ }^{\circ} \mathrm{C}$ $\left(73.4^{\circ} \mathrm{F}\right)$ in all interior zones during all of the simulations with the following exceptions. For cases with constant generator operation for 18 hours, the air temperature in zones containing the generators was assumed to increase linearly over two hours from $23^{\circ} \mathrm{C}\left(73.4^{\circ} \mathrm{F}\right)$ to $40{ }^{\circ} \mathrm{C}$ $\left(104^{\circ} \mathrm{F}\right)$. After the generator stopped operating, the temperature was assumed to decrease linearly over six hours back to $23^{\circ} \mathrm{C}\left(73.4^{\circ} \mathrm{F}\right)$. The air temperature in zones adjacent to the zone containing the generator was assumed to increase on the same schedule but only to $30{ }^{\circ} \mathrm{C}\left(54{ }^{\circ} \mathrm{F}\right)$. These indoor air temperature schedules in the source zone and adjacent zones are based on the results of a series of experimental studies of generator operation reported by Emmerich et al. (2013). The indoor air temperatures of unconditioned spaces (i.e., crawl spaces, unfinished basements, garages and attics), were held constant at $23^{\circ} \mathrm{C}\left(73.4^{\circ} \mathrm{F}\right)$. This assumption in Persily et al. (2013) does not capture temperature variations in such unconditioned spaces caused by the outdoor weather.

For this study, temperature distributions within the simulated buildings were calculated using a version of the CONTAM model with heat transfer modeling capability (Emmerich 2006, Wang et al. 2012). This model accounts for heat transfer conducted through the building envelopes due to ambient weather conditions and for the heat produced by the generator and thus results in more realistic spatial and temporal temperature variations in the buildings. The generator heat source varied depending on generator size and is reported in Table 2 along with the CO emission rates.

Door and window positions: Interior doors were assumed to be open $5 \mathrm{~cm}$ during the simulations and all exterior doors and windows closed with the following exceptions. Stairway doors between finished living space levels other than the first floor door were modeled with fully open doorways. Kitchen, dining, family and living room doors were modeled as fully open doorways. For cases in which the generator was located in an attached garage, the door from the garage to the house was assumed be open roughly $5 \mathrm{~cm}$ to accommodate an extension cord connecting the generator to appliances in the house.

\subsubsection{Source Locations and Emission Rates}

For each building modeled, scenarios included up to three different source locations, a range of “constant” CO generation rates, and different durations of maintained source emissions. The specific source locations used for each simulated house are listed in Appendix B but in general the source locations included:

- Closed garage (if applicable to the model house)

- First floor room (kitchen or other most likely such room based on floor plan) 
- An additional location in either the basement (if applicable to the model house, bedroom or den furthest away from master bedroom or in smallest bedroom or den if master bedroom is on 1st floor) if finished basement) OR crawlspace (if applicable) OR a second room on the first floor room if there is no basement (bedroom furthest away from master bedroom or other likely space)

The simulations require $\mathrm{CO}$ emission rates $(\mathrm{g} / \mathrm{h})$ and input values for source duration and source heat release rate. These were supplied by CPSC staff, derived from an analysis of currently marketed generators, and generator products/sizes identified in CPSC incident databases (Hnatov et al. 2016). Table 2 summarizes values for all of these modeled variables for four size ranges of generator products: $\mathrm{HH}$ (generators powered by spark-ignited (SI) handheld engines), C1 (generators powered by SI Class I non-handheld engines), C2 (generators powered by SI Class II non-handheld single cylinder engines) and C2 twin (generators powered by SI Class II nonhandheld twin cylinder engines). For each generator size category, the baseline $\mathrm{CO}$ emission rate represents three times the EPA's 6-mode weighted ambient CO emission rates of carbureted engines used in multiple brands of popular generators (see Appendix $C$ for more information on this factor). Table 2 also contains six potential rule-compliant reduced $\mathrm{CO}$ emission rates (to support the analysis of multiple options for cost-benefit analysis). The run-time represents the generators' advertised run time (determined by the CPSC market analysis to be representative of typical generators of that engine class, Hnatov et al. 2016), for one full tank of gasoline, when operated at half-load, which nominally represents the weighted load of the 6-mode profile. Two schedules were used for each generator size. The first was a full tank operation starting at 12 a.m. (called full schedule) and the second was a half tank operation starting at 8 a.m. (called half schedule).

Table 2 Baseline and reduced CO emission rates, run-times and heat rates for the generators

\begin{tabular}{|l|l|l|l|l|l|}
\hline $\begin{array}{l}\text { Generator } \\
\text { size }\end{array}$ & $\begin{array}{l}\text { Baseline CO } \\
\text { emission rate at } \\
\left.\text { reduced } \mathbf{O}_{2} \mathbf{( g / h}\right)\end{array}$ & $\begin{array}{l}\text { Reduced CO emission } \\
\text { rates } \mathbf{( g / h )}\end{array}$ & $\begin{array}{l}\text { Run-time } \\
\mathbf{( h )}\end{array}$ & $\begin{array}{l}\text { Heat } \\
\text { release } \\
\text { rate (kW) }\end{array}$ & Notes \\
\hline HH & 900 & $50,125,250,500$ & 8 & 2 & $\begin{array}{l}\text { Only used in } \\
\text { DH8 and } \\
\text { MH1mod }\end{array}$ \\
\hline C1 & 1800 & $50,125,250,500,1000$ & 9 & 6 & \\
\hline C2 single & 4700 & $\begin{array}{l}50,125,250,500,1000, \\
2000\end{array}$ & 10 & 13 & \\
\hline C2 twin & 9100 & $\begin{array}{l}50,125,250,500,1000, \\
2000\end{array}$ & 9 & 25 & $\begin{array}{l}\text { Only used in } \\
\text { GAR1 and } \\
\text { GAR3 }\end{array}$ \\
\hline
\end{tabular}

Notes: Baseline generators were simulated with a CO rate two-thirds of the table value for the first 2 hours of operation as the enclosed space starts at ambient oxygen level. Engine classifications are U.S. Environmental Protection Agency (EPA) definitions. 


\subsection{Simulation cases and output analysis}

The simulations that were run are depicted in Figure 1, which shows the 40 buildings ( 37 houses and 3 detached garages), 3 source locations, up to 10 source strength levels, 28 days of weather and 2 schedule types. Note that not all combinations were simulated as not all buildings have garages, basements or crawlspaces and the $\mathrm{HH}$ and $\mathrm{C} 2$ twin sources were only used in 2 buildings.

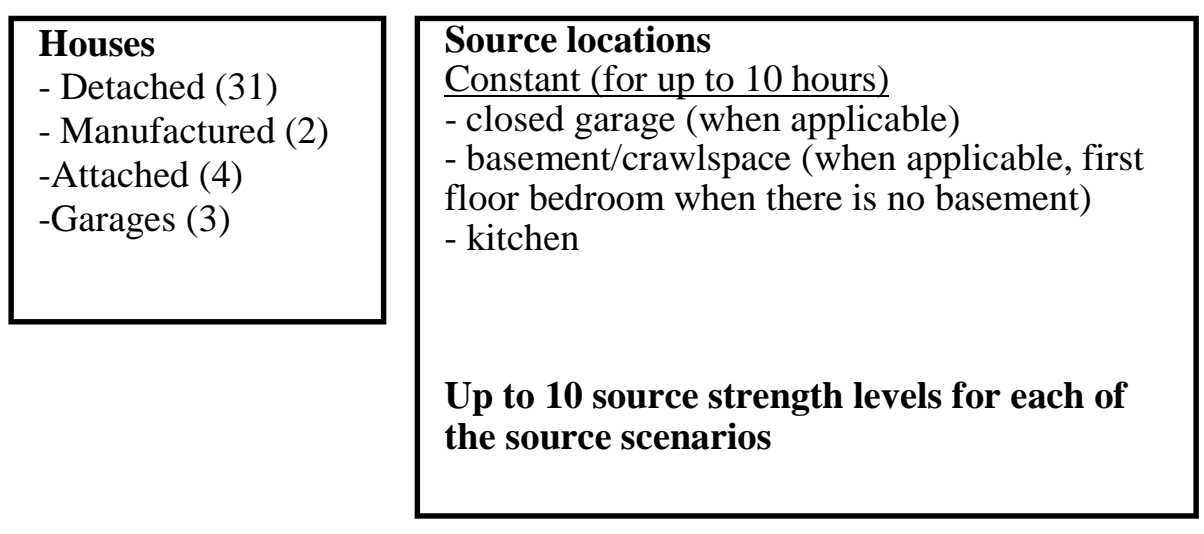

Figure 1 Schematic showing simulation cases

\begin{tabular}{|l|}
\hline Weather/schedule \\
- 14 days cold \\
- 7 days warm \\
- 7 days transition \\
\\
Full and half \\
schedule for each \\
day
\end{tabular}

Each simulation corresponds to one house, one source location, one source strength, one schedule and one day of weather. The output of each simulation are the $\mathrm{CO}$ concentrations versus time in each zone of the house. Based on the simulation time step of 1 min, the output consists of 1440 concentrations values in each zone over each 24-h simulation. As noted earlier, the CO generation commenced either at the beginning of each 24-h period for the full schedule or at 8 a.m. for the half schedule. After the CO generation stopped, the indoor CO concentrations started decreasing back to ambient levels.

\subsection{COHb time profile calculation}

The COHb (\%) level reflects the percentage share of the body's total hemoglobin pool occupied by CO. In acute, modeled exposure scenarios, it serves as a useful measure to compare expected poisoning severity in a reference individual. COHb levels were calculated for an occupant in each occupiable zone of the house and garage over the 24-h simulation period using the CoburnForster-Kane (CFK) non-linear differential equation (Peterson and Stewart 1975, Coburn et al. 1965) and input values determined in consultation with CPSC, specifically three RMV (respiratory minute volume) values of $10 \mathrm{~L} / \mathrm{min}$ (representing a time-weighted average 24 hour value for males and females 16 to 80 years old, for expected residential indoor activity), $12 \mathrm{~L} / \mathrm{min}$ (representing a time-weighted 75th percentile 24 hour value for adult males and females 16 to 80 years old for expected residential indoor activity), and $6 \mathrm{~L} / \mathrm{min}$ (representing a baseline 75th percentile 24 hour value for adult males and females 16 to 80 years old for sleeping/sedentary activity levels, especially likely in bedrooms) and an initial COHb level of $0.00056 \mathrm{ml} / \mathrm{ml}$. 


\section{RESULTS}

This section presents a sample of the results of the simulations discussed in the previous section for four of the modeled buildings.

\subsection{Sample results for a small manufactured house (MH1mod)}

This section presents sample results for the building MH1mod, which was created for this project as a smaller version of the manufactured house MH-1 (also included in this study) from the NIST suite of homes discussed earlier. Figure 2 shows the floorplan of MH1mod as represented in the CONTAM Sketchpad. MH1mod has $82.5 \mathrm{~m}^{2}$ of floor area with 2 bedrooms, 1 bathroom and a kitchen. MH1mod was modeled with generators located in the kitchen, bedroom 2 and the crawlspace.

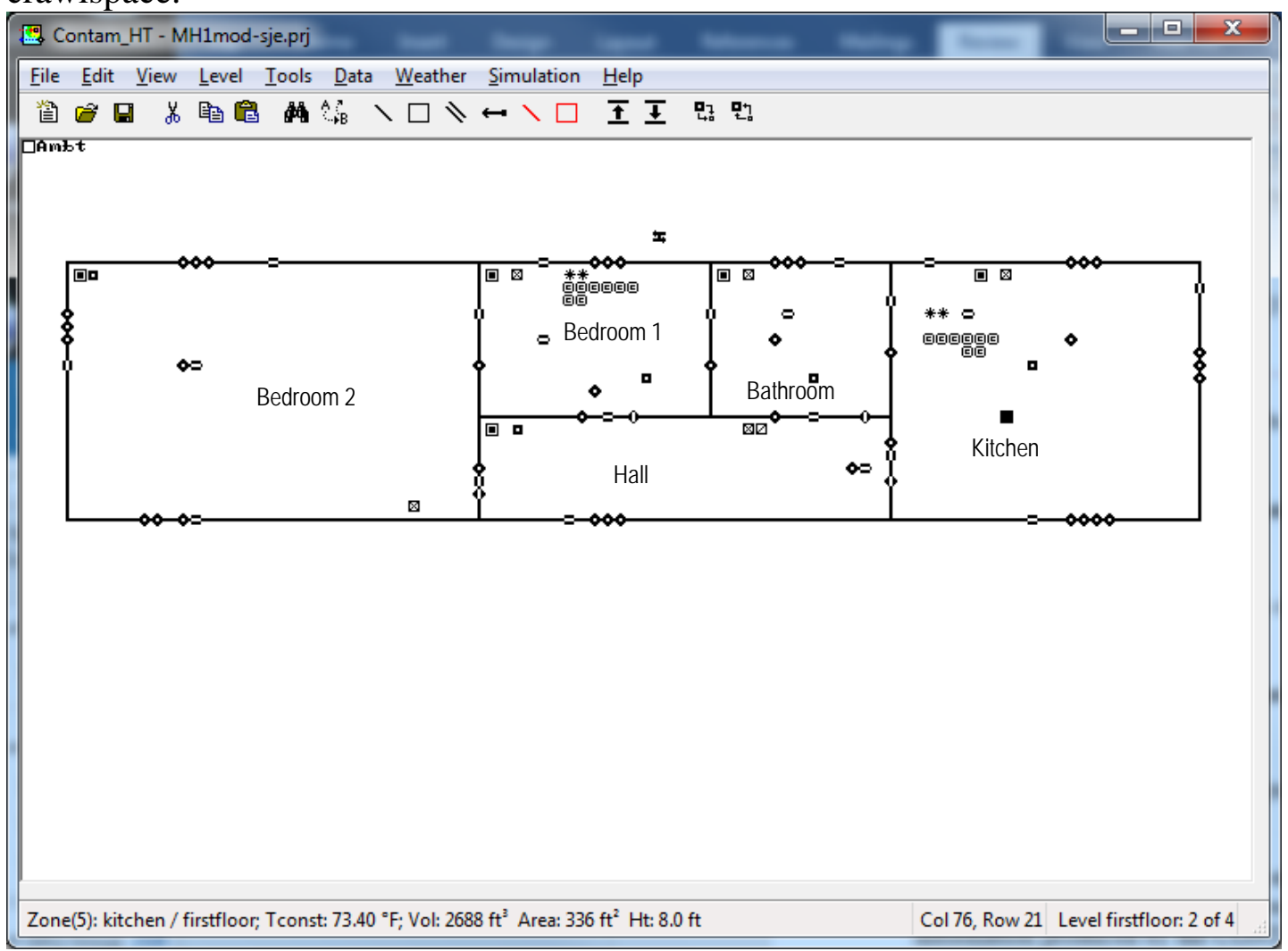

Figure 2 Floor plan of house MH1mod as represented in CONTAM

Figure 3 shows individual zone CO concentration results for the source located in bedroom 1 of house MH1mod on January $1^{\text {st }}$. Note that Figure 3 (and each of the following results plots) shows the results zone by zone for a single day along the $\mathrm{x}$-axis. The concentration of $\mathrm{CO}$ in bedroom 1 reached a peak of over $8,000 \mu \mathrm{L} / \mathrm{L}$ ( $\mu \mathrm{L} / \mathrm{L}$ are equivalent to the commonly used unit for $\mathrm{CO}$ concentration of parts per million by volume or $\mathrm{ppm}_{\mathrm{v}}$ ) for the $\mathrm{HH}$ baseline source and peak concentrations ranged from around $1700 \mu \mathrm{L} / \mathrm{L}$ to $3000 \mu \mathrm{L} / \mathrm{L}$ in the other zones. Peak concentrations for the reduced rates of $50 \mathrm{~g} / \mathrm{h}$ to $500 \mathrm{~g} / \mathrm{h}$ were lower than the HH baseline source peaks by $40 \%$ to more than $90 \%$. 
Figure 4 shows individual zone COHb levels calculated with an RMV $=10 \mathrm{~L} / \mathrm{min}$ for the same cases as Figure 3 (source in bedroom 1 on January $1^{\text {st }}$ ). Note that the calculation of COHb was cut off at $95 \%$ for all cases because the calculated COHb levels are not meaningful at these high levels. Therefore, in some of the $\mathrm{COHb}$ figures the $\mathrm{COHb}$ is shown to artificially level off at $95 \%$. For reference, $\mathrm{COHb}$ levels of $70 \%$ or greater are associated with death in less than 3 min, levels of $50 \%$ are associated with headache, dizziness and nausea in 5 min to 10 min and death within $30 \mathrm{~min}$, levels of $30 \%$ with dizziness, nausea and convulsions within 45 min and becoming insensible within $2 \mathrm{~h}$, and levels of $20 \%$ with a slight headache in $2 \mathrm{~h}$ to $3 \mathrm{~h}$ and a loss of judgment (Goldstein 2008). In the absence of rescue, COHb levels that reach $60 \%$ or more, typically end in acute lethal outcome (personal communication from S. Inkster of U.S. CPSC). The COHb quickly exceeded $40 \%$ in all zones for both the $\mathrm{HH}$ and $500 \mathrm{~g} / \mathrm{h}$ sources, but remained below $40 \%$ in all zones for the $50 \mathrm{~g} / \mathrm{h}$ source.

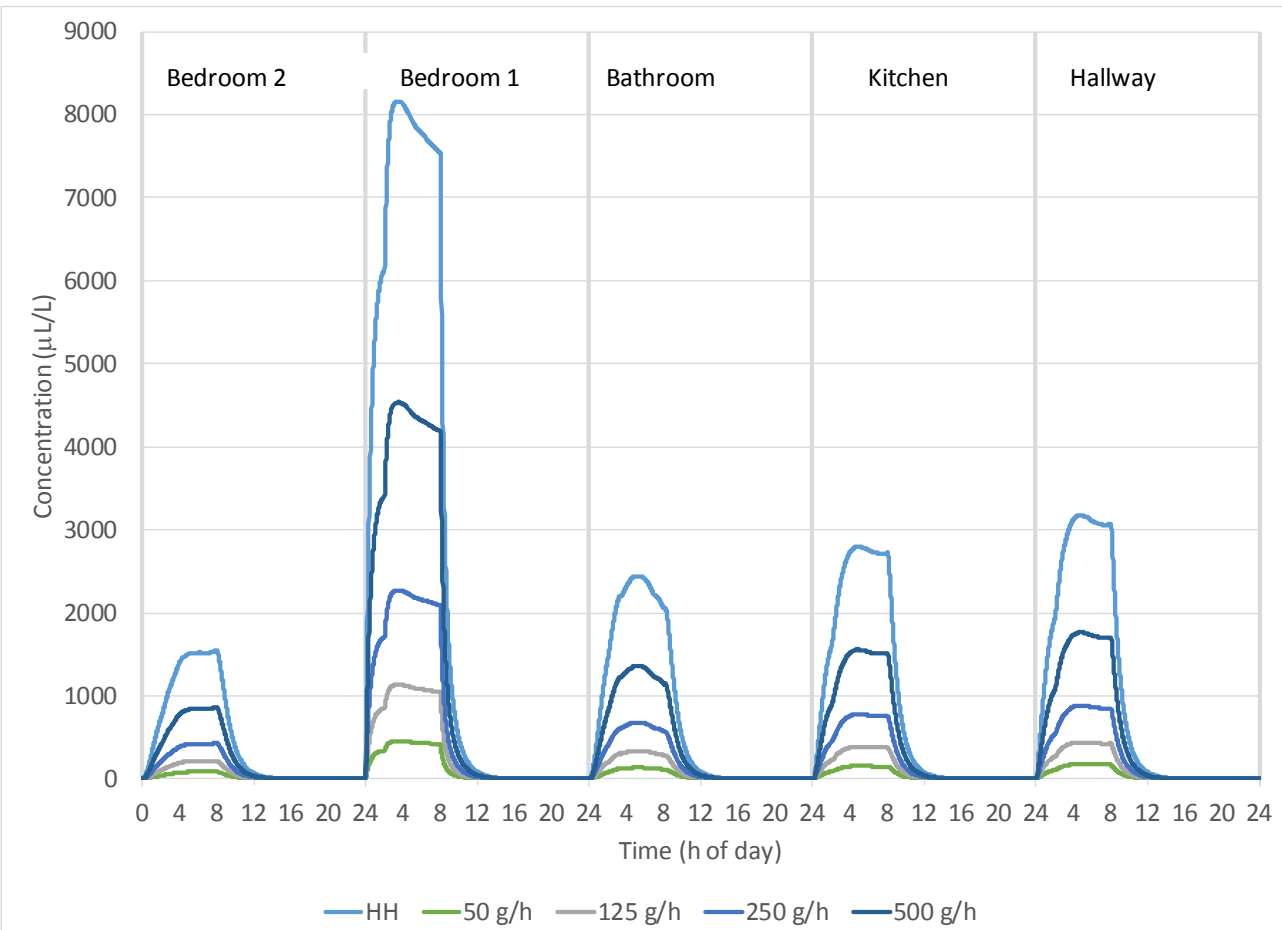

Figure 3 Individual zone transient CO results for the HH source in Bedroom 1 of MH1mod on January $1^{\text {st }}$ 


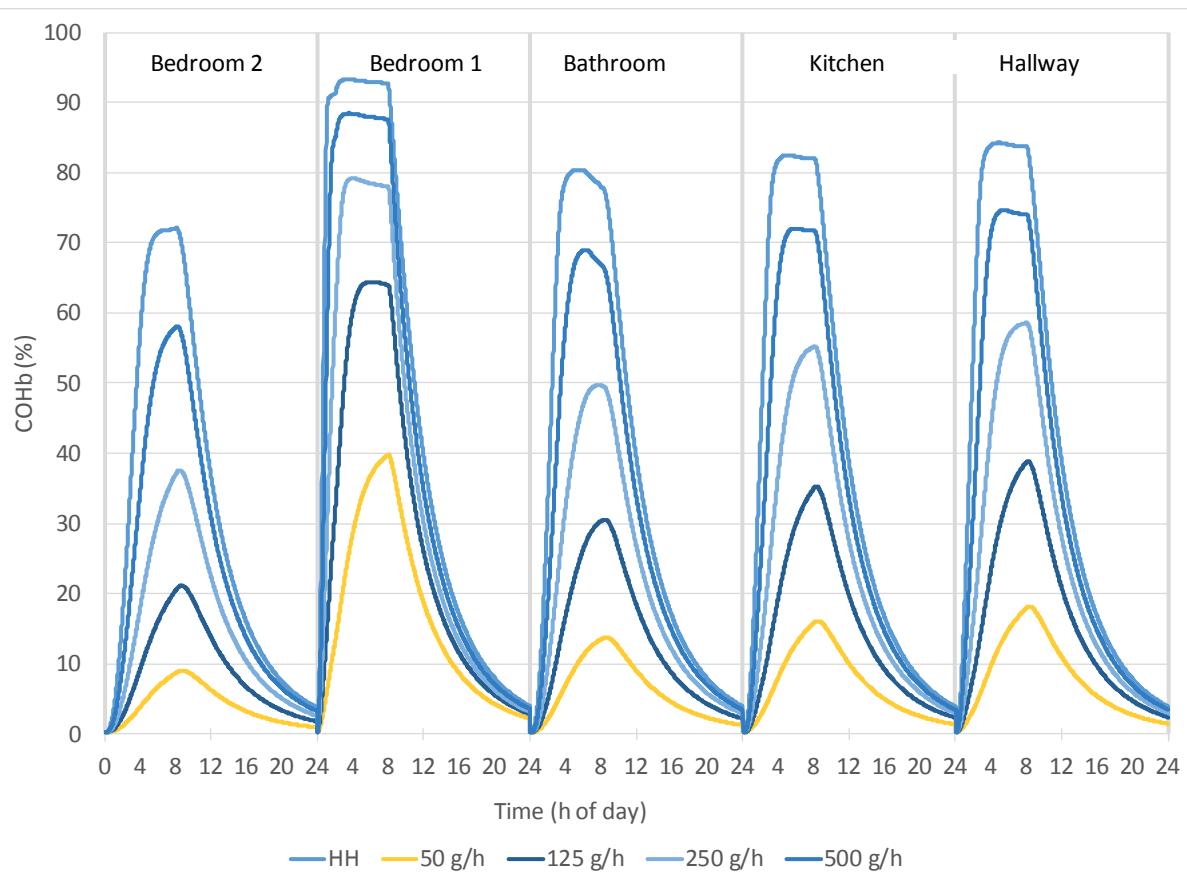

Figure 4 Individual zone transient $\mathrm{COHb}(\mathrm{RMV}=10 \mathrm{~L} / \mathrm{min})$ results for the $\mathrm{HH}$ source in Bedroom 1 of MH1mod on January $1^{\text {st }}$. Note that the calculation of COHb was cut off at $95 \%$ for all cases.

Figure 5 shows individual zone CO concentration results for the source located in bedroom 1 of house MH1mod on July $25^{\text {th }}$. Due to the lower infiltration rate caused by the smaller indoor to outdoor temperature difference during the warmer weather, the concentration of CO in bedroom 1 reaches a much higher peak of over $16,000 \mu \mathrm{L} / \mathrm{L}$ for the HH baseline source (900 g/h), with peak concentrations ranging from around $7000 \mu \mathrm{L} / \mathrm{L}$ to $10,000 \mu \mathrm{L} / \mathrm{L}$ in the other zones. Reductions in peak concentrations for the reduced emission rates of $50 \mathrm{~g} / \mathrm{h}$ to $500 \mathrm{~g} / \mathrm{h}$ compared to the baseline HH source were similar to the January $1^{\text {st }}$ reductions of $40 \%$ to over $90 \%$.

Figure 6 shows zone $\mathrm{COHb}$ values calculated with an $\mathrm{RMV}=10 \mathrm{~L} / \mathrm{min}$ for the same cases as Figure 5 (source in bedroom 1 on July $25^{\text {th }}$ ). The COHb quickly exceeded $40 \%$ in all zones for most of the source strengths. The COHb remained below or peaked at around $40 \%$ in the nonsource zones for the $50 \mathrm{~g} / \mathrm{h}$ source. 


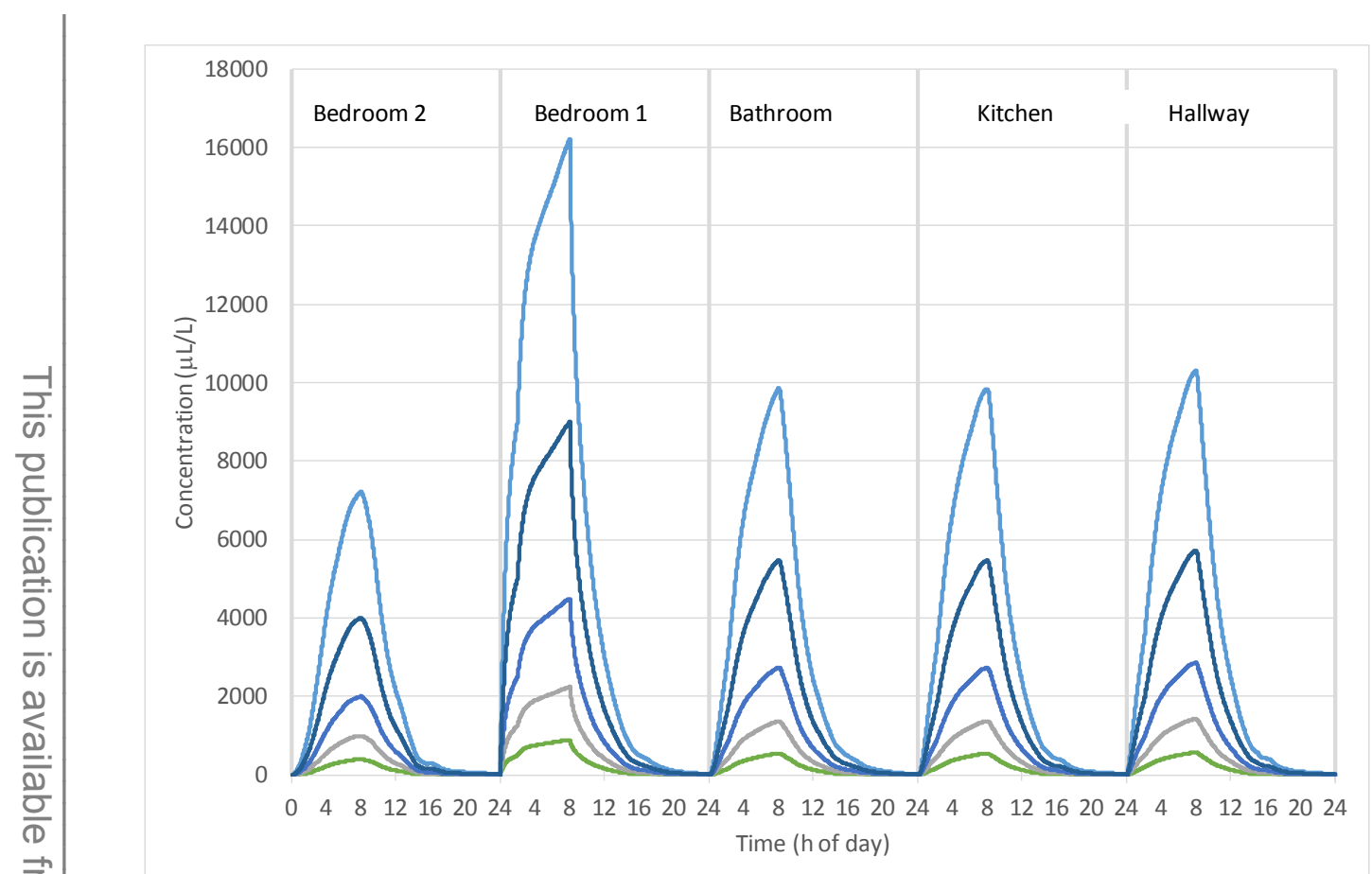

- $\mathrm{HH}-50 \mathrm{~g} / \mathrm{h}-125 \mathrm{~g} / \mathrm{h}-250 \mathrm{~g} / \mathrm{h}-500 \mathrm{~g} / \mathrm{h}$

Figure 5 Individual zone transient CO results for the HH source in Bedroom 1 of MH1mod on July $25^{\text {th }}$

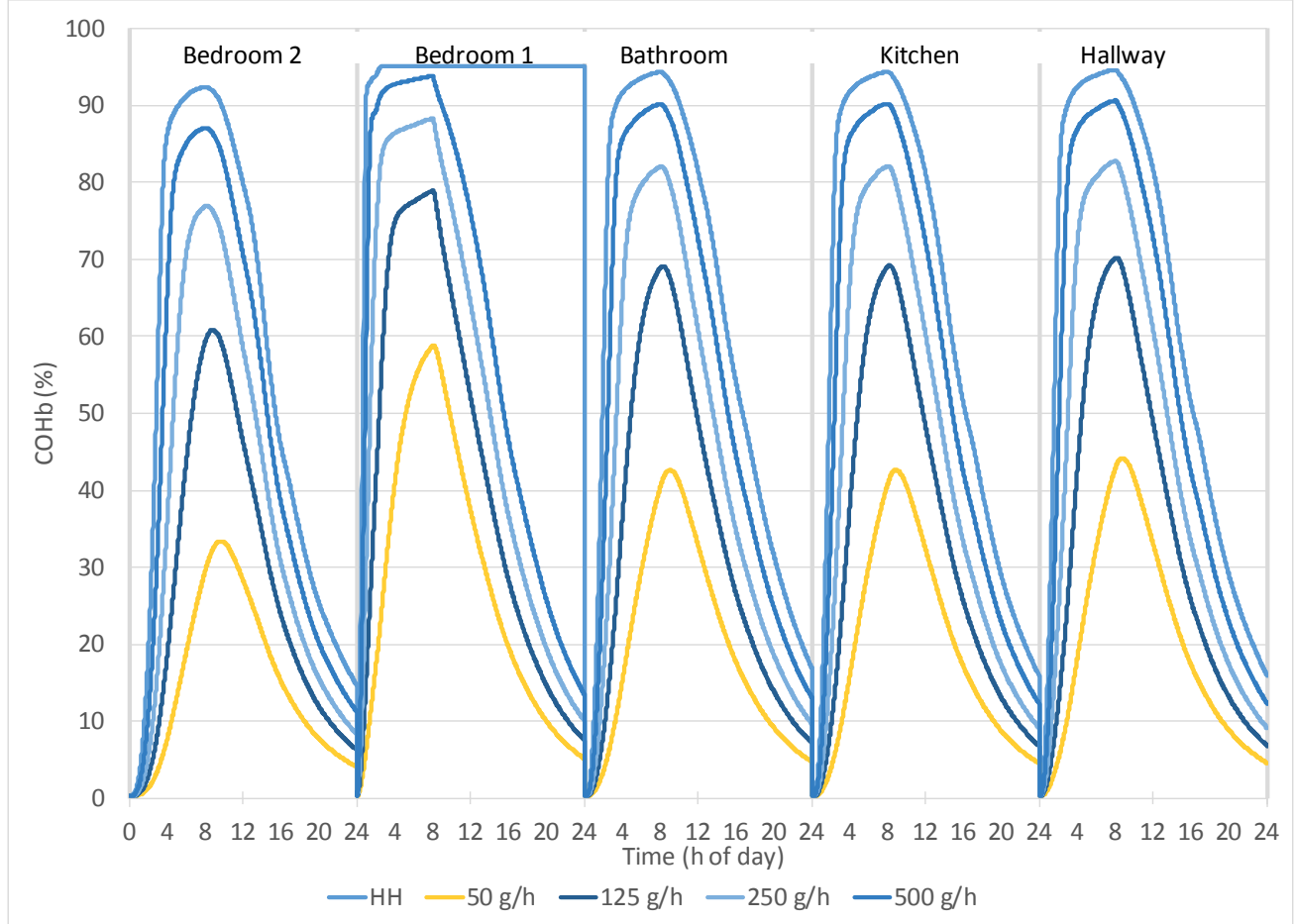

Figure 6 Individual zone transient $\mathrm{COHb}$ (with $\mathrm{RMV}=10 \mathrm{~L} / \mathrm{min}$ ) results for the $\mathrm{HH}$ source in Bedroom 1 of MH1mod on July $25^{\text {th }}$ 
Figures 7 and 8 show individual zone $\mathrm{CO}$ concentration and COHb results, respectively, for the C1 source (1800 g/h, generators powered by SI class I non-handheld engines) and reduced rate sources located in bedroom 1 of house MH1mod on January $1^{\text {st }}$. Since the C1 source is twice as strong as the $\mathrm{HH}$ source, the $\mathrm{CO}$ concentrations for the baseline case reach much higher concentrations in Figure 7 compared to Figure 3. However, the increase is less than a full doubling, which is likely due primarily to air change rate differences since the C1 source has a higher heat release rate and thus results in higher zone temperatures. The higher zone temperatures mean the indoor-outdoor temperature difference that drives infiltration is larger. The higher air change rate with the $\mathrm{C} 1$ source also results in somewhat lower $\mathrm{CO}$ concentrations for the reduced rate sources in Figure 7 compared to Figure 3. Reductions in peak concentrations for the reduced emission rates of $50 \mathrm{~g} / \mathrm{h}$ to $1000 \mathrm{~g} / \mathrm{h}$ compared to the baseline C1 source peaks ranged from $40 \%$ to over $90 \%$. The COHb results shown in Figure 8 were generally similar to those of Figure 4 with somewhat higher results for the larger $\mathrm{C} 1$ baseline case compared to the $\mathrm{HH}$ baseline as the $\mathrm{COHb}$ quickly exceeded $40 \%$ in all zones for most of the source strengths. The COHb remained below $40 \%$ in all zones for the $50 \mathrm{~g} / \mathrm{h}$ source and in the non-source zones for the $125 \mathrm{~g} / \mathrm{h}$ source.

Figures 9 and 10 show individual zone CO concentration and COHb results, respectively, for the C1 source (1800 g/h) and reduced rate sources located in bedroom 1 of house MH1mod on July $25^{\text {th }}$. As with the January $1^{\text {st }}$ results the stronger C1 source resulted in higher, but less than double, $\mathrm{CO}$ concentrations for the baseline case in Figure 9 compared to Figure 5. Reductions in peak concentrations for the reduced rates of $50 \mathrm{~g} / \mathrm{h}$ to $1000 \mathrm{~g} / \mathrm{h}$ compared to the baseline C1 source peaks again ranged from around $40 \%$ to over $90 \%$. The COHb results shown in Figure 10 were generally similar to those of Figure 6 with somewhat higher results for the larger C1 baseline case compared to the $\mathrm{HH}$ baseline as the $\mathrm{COHb}$ quickly exceeded $40 \%$ in all zones for most of the source strengths. The COHb remained below $40 \%$ in non-source zones for the $50 \mathrm{~g} / \mathrm{h}$ source only. 


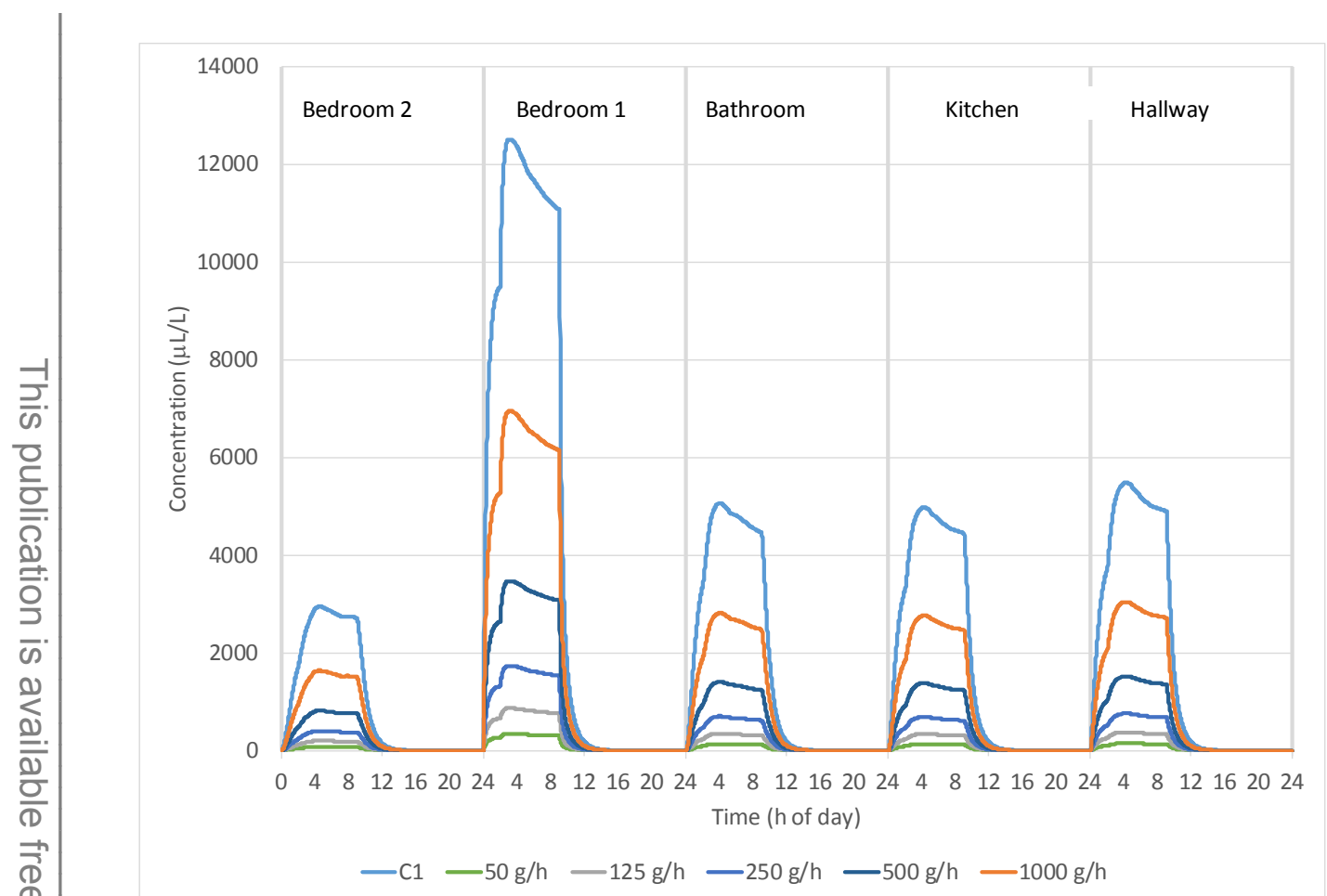

Figure 7 Individual zone transient CO results for the C1 source in Bedroom 1 of MH1mod on January $1^{\text {st }}$

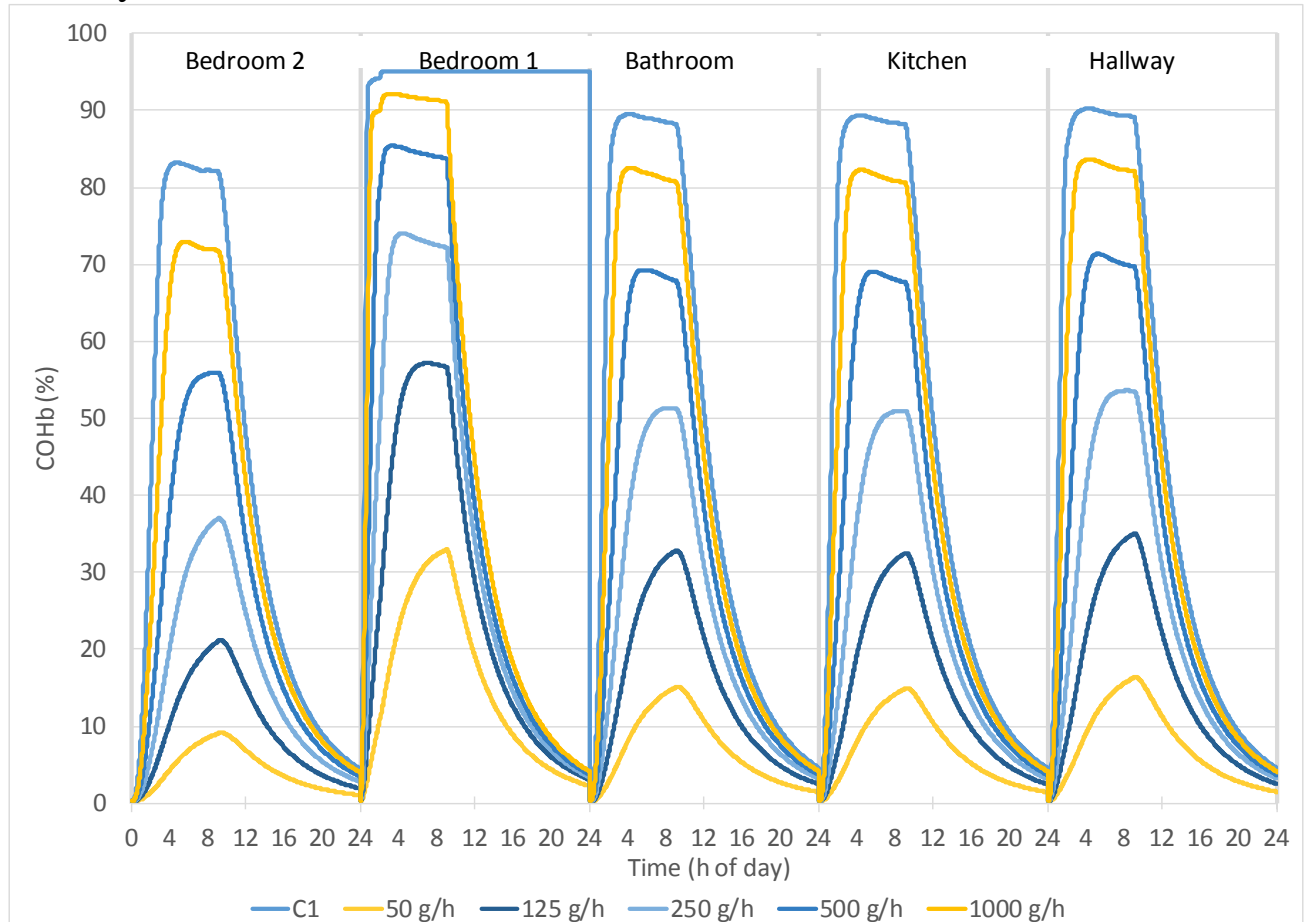

Figure 8 Individual zone transient $\mathrm{COHb}$ (with $\mathrm{RMV}=10 \mathrm{~L} / \mathrm{min}$ ) results for the $\mathrm{C} 1$ source in Bedroom 1 of MH1mod on January $1^{\text {st }}$ 


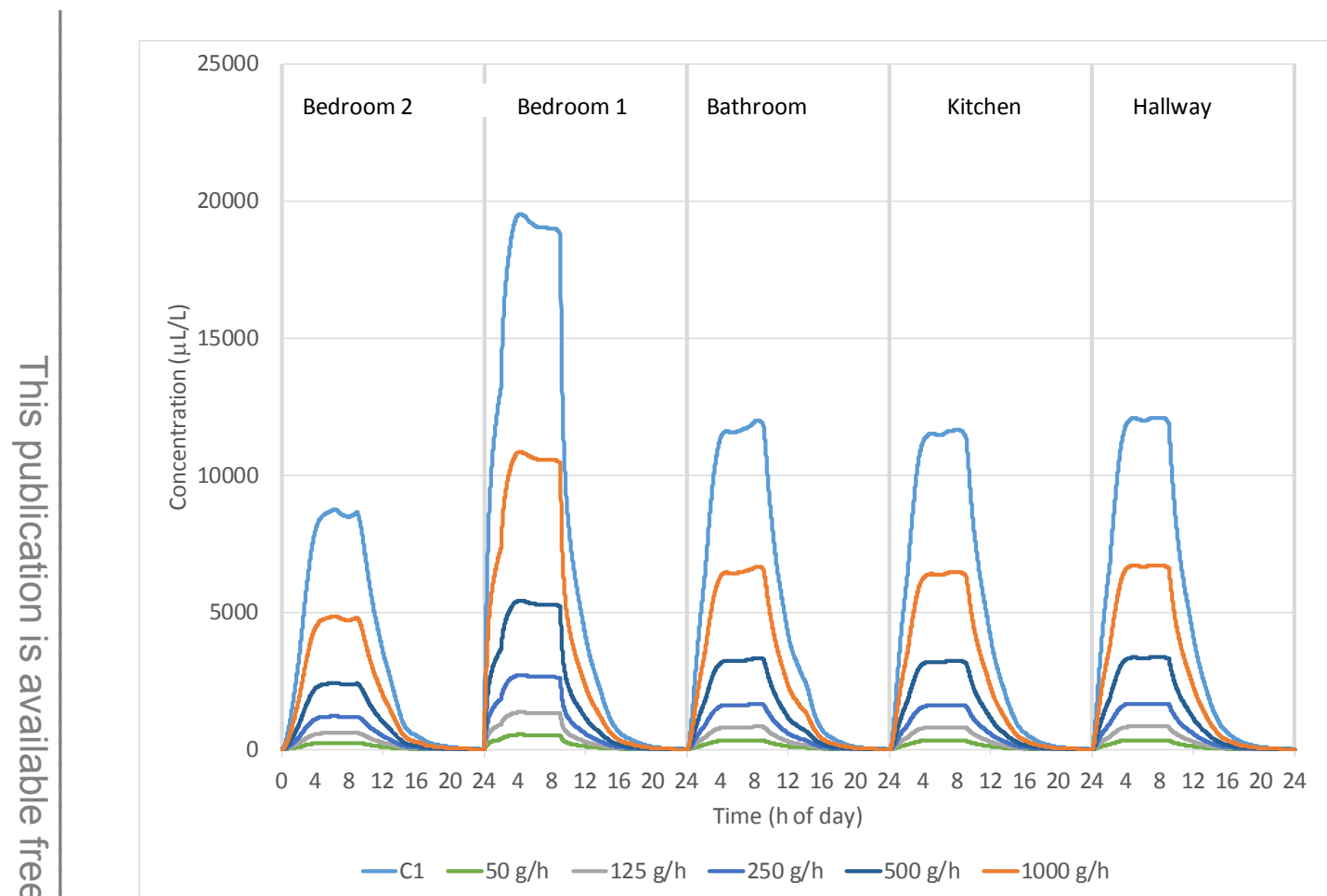

Figure 9 Individual zone transient CO results for the C1 source in Bedroom 1 of MH1mod on July $25^{\text {th }}$

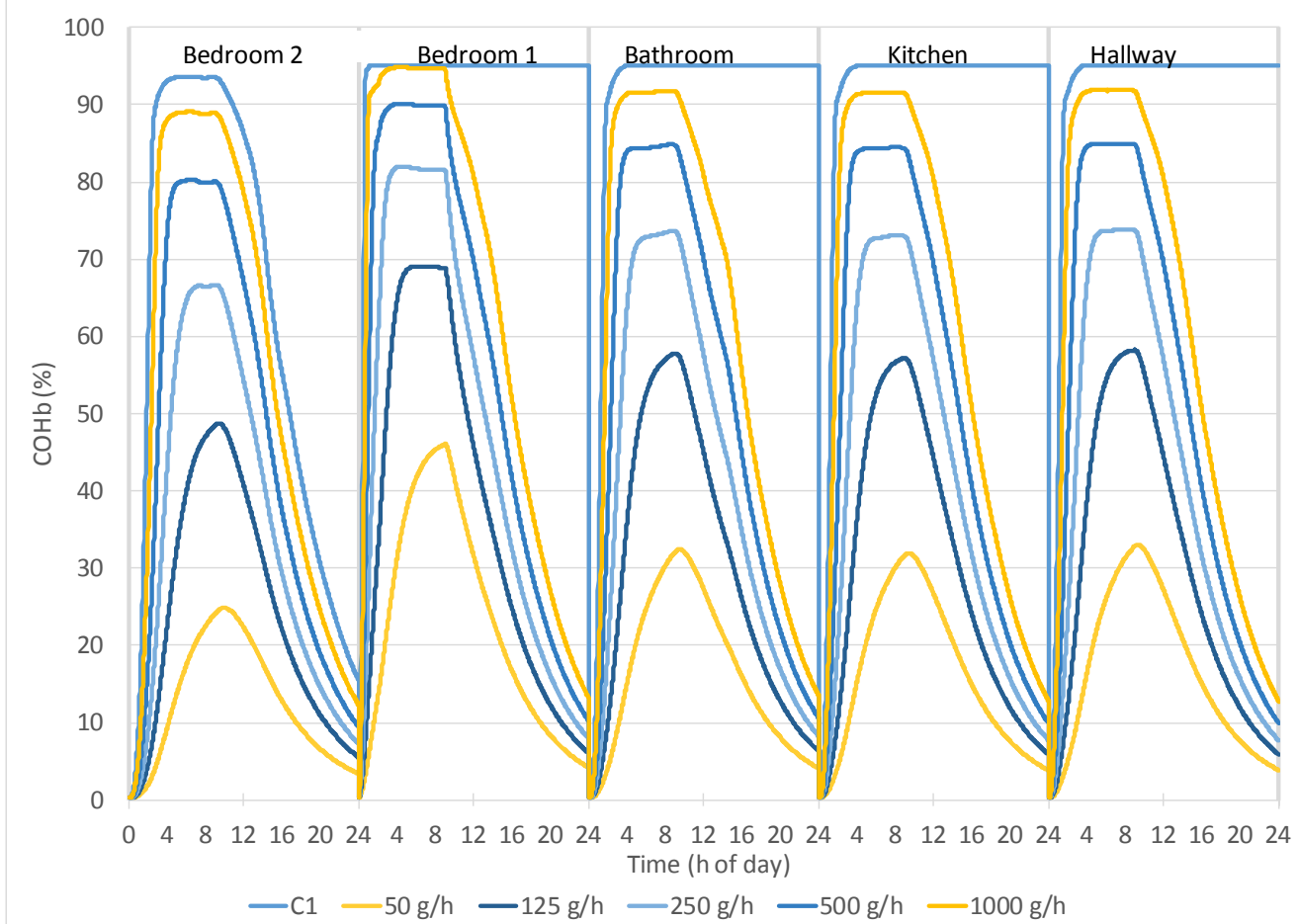

Figure 10 Individual zone transient $\mathrm{COHb}$ (with $\mathrm{RMV}=10 \mathrm{~L} / \mathrm{min}$ ) results for the $\mathrm{C} 1$ source in Bedroom 1 of MH1mod on July $25^{\text {th }}$ 
The previous results in Figures through 9 were all for cases with the generator in the bedroom 1 zone. Figures 11 and 12 show individual zone $\mathrm{CO}$ concentration and $\mathrm{COHb}$ results, respectively, for the C1 source and reduced sources for the generator located in the kitchen of house MH1mod on January $1^{\text {st }}$. As discussed in Section 2.2.1, kitchens, including the kitchen zone of MH1mod, were connected to adjacent zones with fully open doorways rather than slightly ajar doors. As seen in Figure 11, this results in lower CO concentrations in the source zone (kitchen of Figure 11 compared to bedroom 1 of Figure 7) but higher CO concentrations in the non-source zones. However, reductions in peak concentrations for the reduced rates of $50 \mathrm{~g} / \mathrm{h}$ to $1000 \mathrm{~g} / \mathrm{h}$ compared to the baseline C1 source still ranged from around $40 \%$ to over $90 \%$. The COHb results shown in Figure 12 were generally similar to those of Figure 8, with the COHb quickly exceeding $40 \%$ in all zones for most of the source strengths but remaining near or below $40 \%$ in all zones for the $50 \mathrm{~g} / \mathrm{h}$ source and in the non-source zones for the $125 \mathrm{~g} / \mathrm{h}$ source.

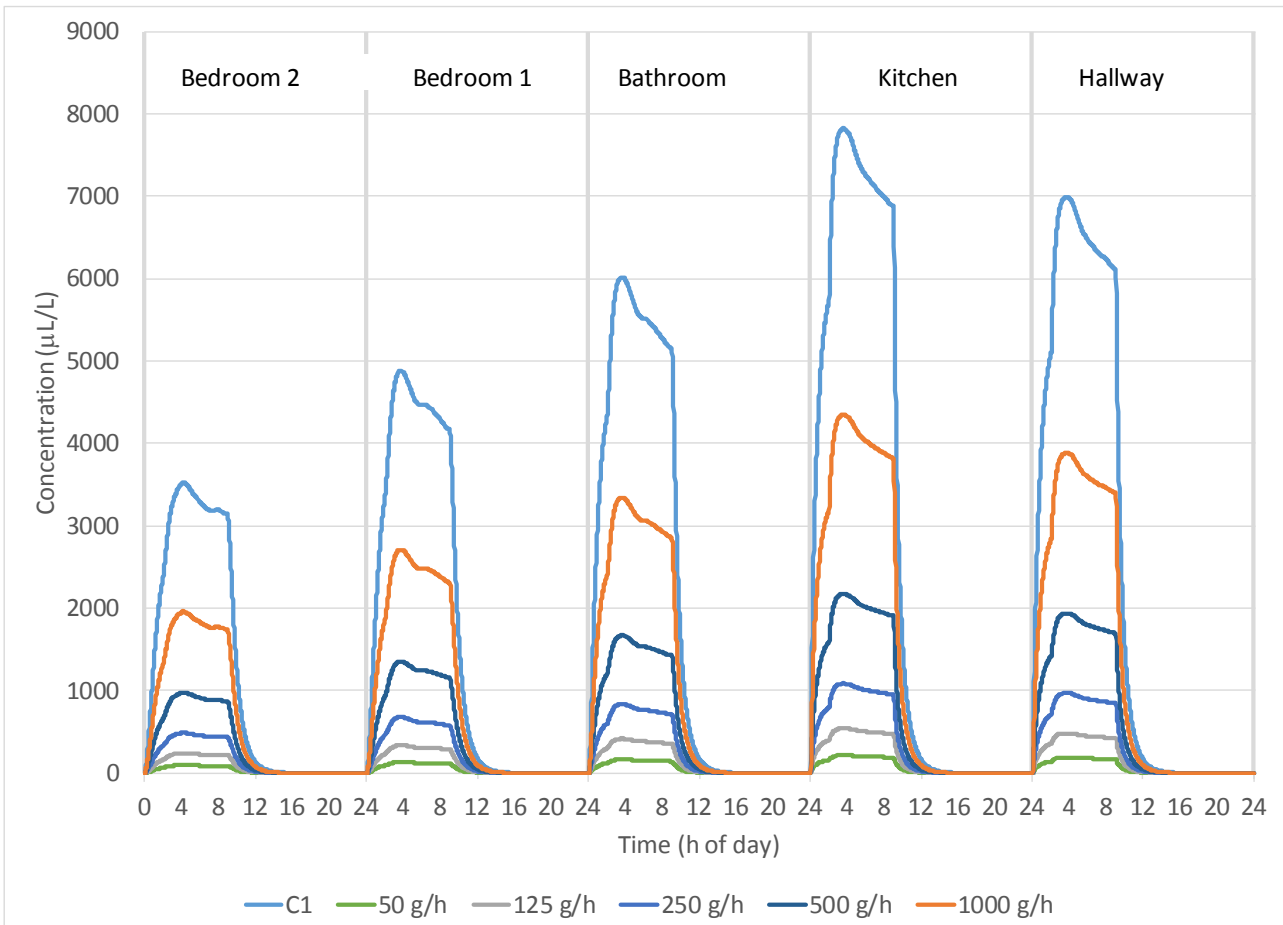

Figure 11 Individual zone transient CO results for the $\mathrm{C} 1$ source in Kitchen of MH1mod on January $1^{\text {st }}$ 


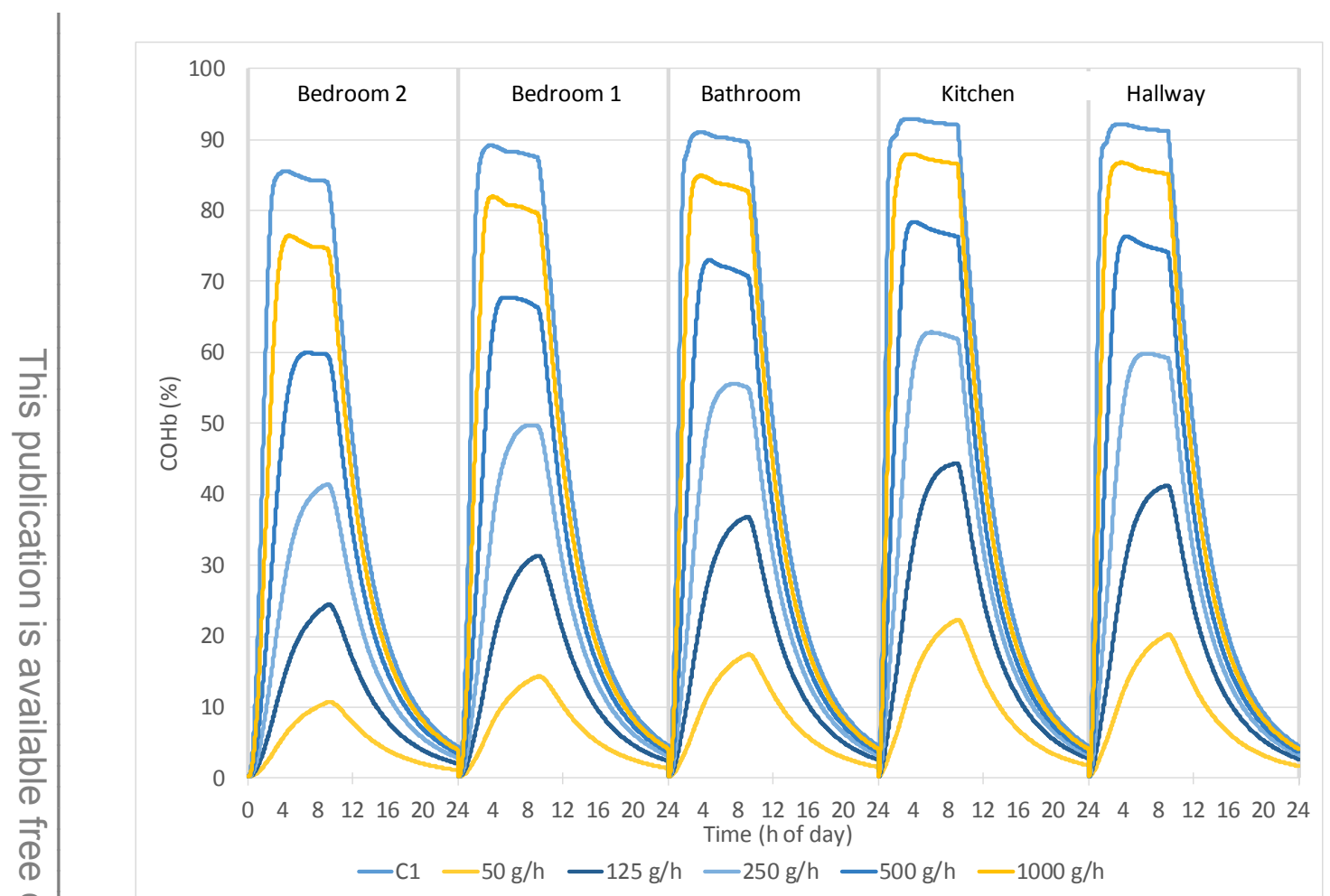

Figure 12 Individual zone transient $\mathrm{COHb}$ (with $\mathrm{RMV}=10 \mathrm{~L} / \mathrm{min}$ ) results for the $\mathrm{C} 1$ source in Kitchen of MH1mod on January $1^{\text {st }}$

Figures 13 and 14 show individual zone $\mathrm{CO}$ concentration and $\mathrm{COHb}$ results, respectively, for the C1 source and reduced rate sources located in the kitchen of house MH1mod on July $25^{\text {th }}$. As with the bedroom 1 source location, the warmer temperatures (and lower air change rates) on July $25^{\text {th }}$ result in higher $\mathrm{CO}$ concentrations and $\mathrm{COHb}$ compared to the January $1^{\text {st }}$ results shown in Figures 11 and 12. 


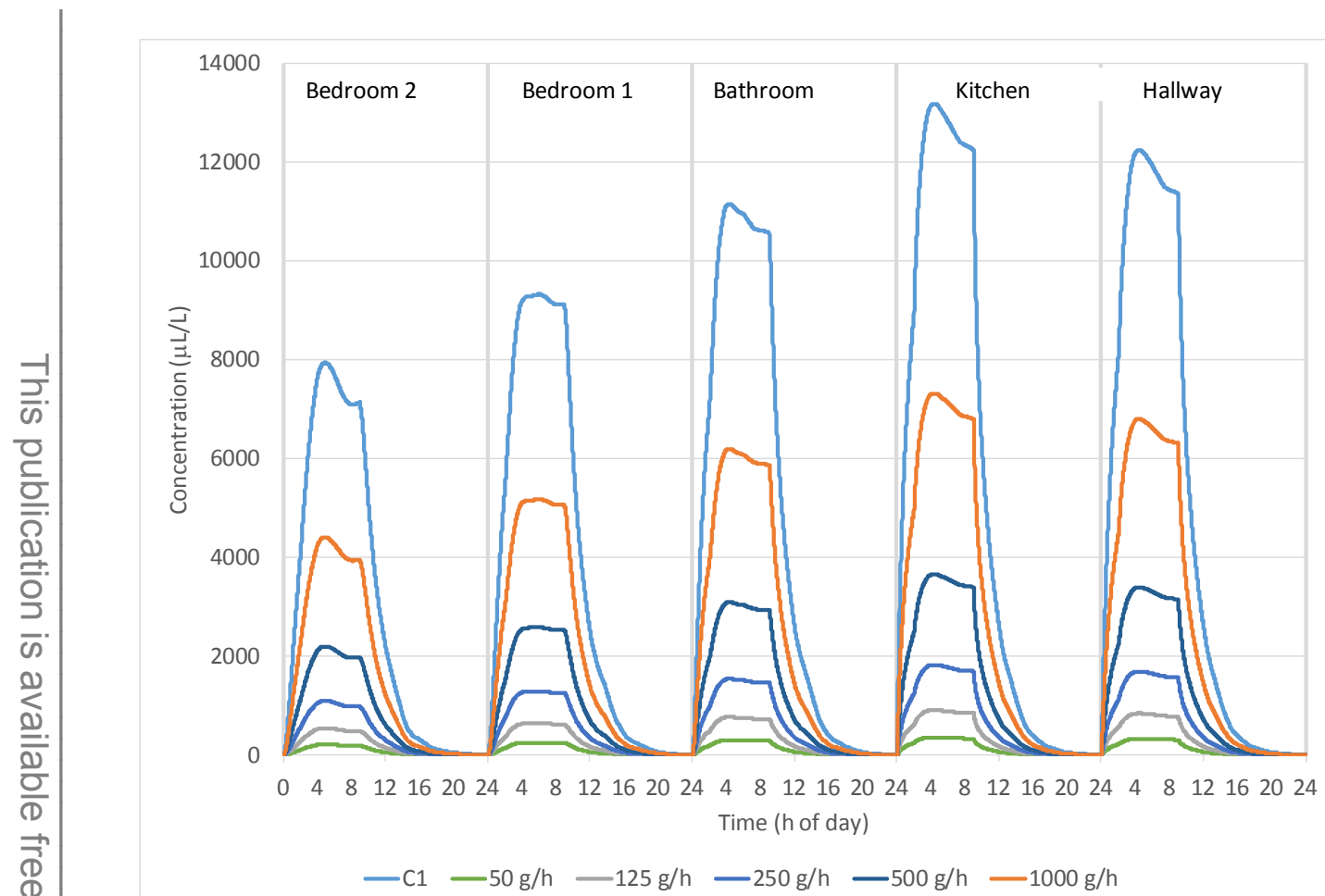

Figure 13 Individual zone transient CO results for the C1 source in Kitchen of MH1mod on July $25^{\text {th }}$

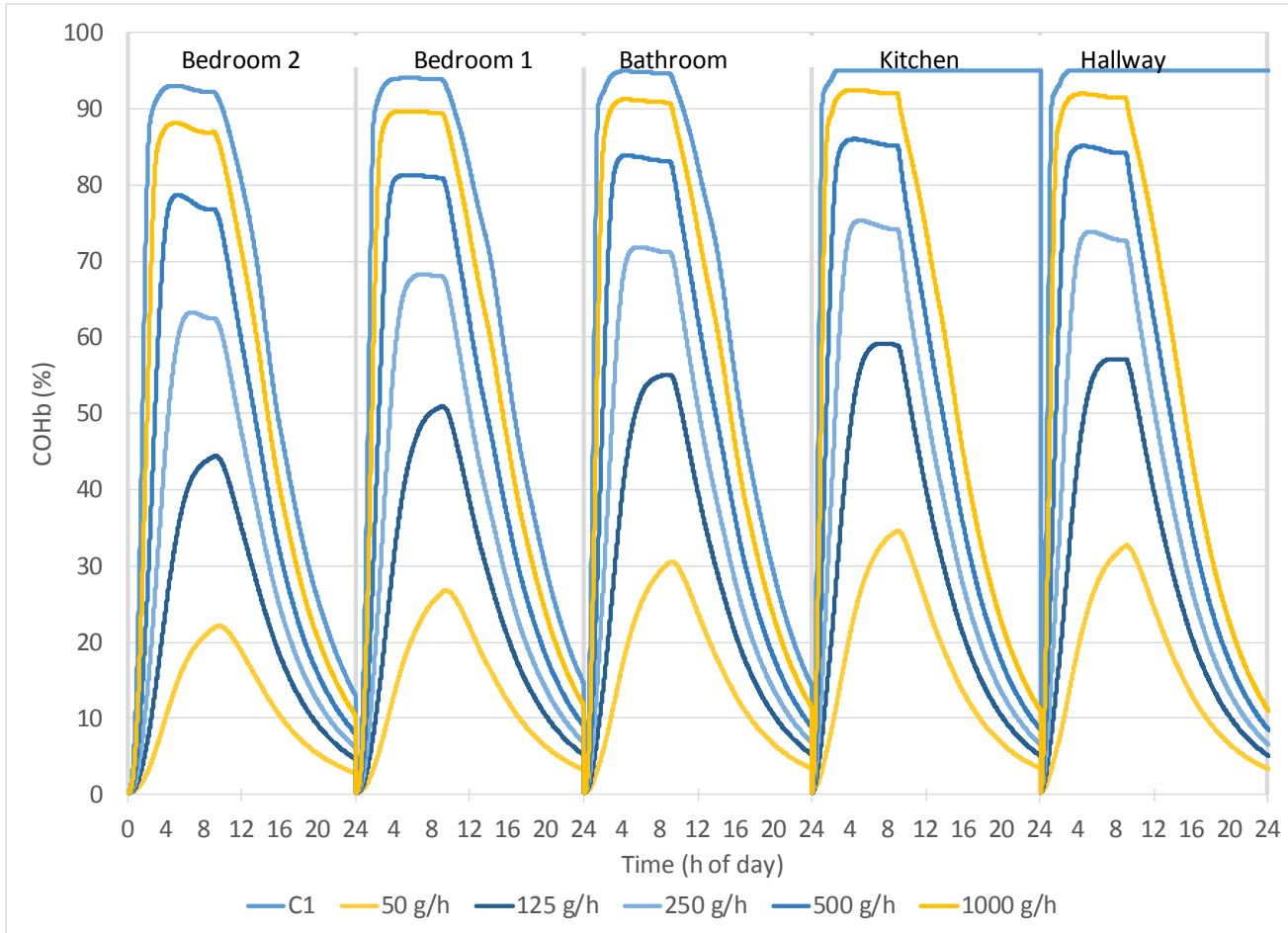

Figure 14 Individual zone transient $\mathrm{COHb}$ (with $\mathrm{RMV}=10 \mathrm{~L} / \mathrm{min}$ ) results for the $\mathrm{C} 1$ source in Kitchen of MH1mod on July $25^{\text {th }}$ 


\subsection{Sample results for a mid-sized detached house with basement and integral garage (DH- 45mod)}

This section presents example results for building DH-45mod, which was created for this project based on the detached house DH-45 (also included in this study) from the NIST suite of homes. As described in Appendix B, two modifications were made to the DH-45 model. Part of the unfinished basement was converted to an integral garage and the air leakage was modified based on year built and floor area to represent the newest category of construction (1990 and newer) in the suite of homes analysis. Figure 15 shows the floorplan of DH-45mod as represented in the CONTAM Sketchpad. DH-45mod has $180 \mathrm{~m}^{2}$ of floor area with a kitchen, dining room, living room, two bathrooms and one bedroom on the first floor and three bedrooms, a bathroom and a den on the second floor. DH-45mod was modeled with generators located in the kitchen, the unfinished basement and the garage.

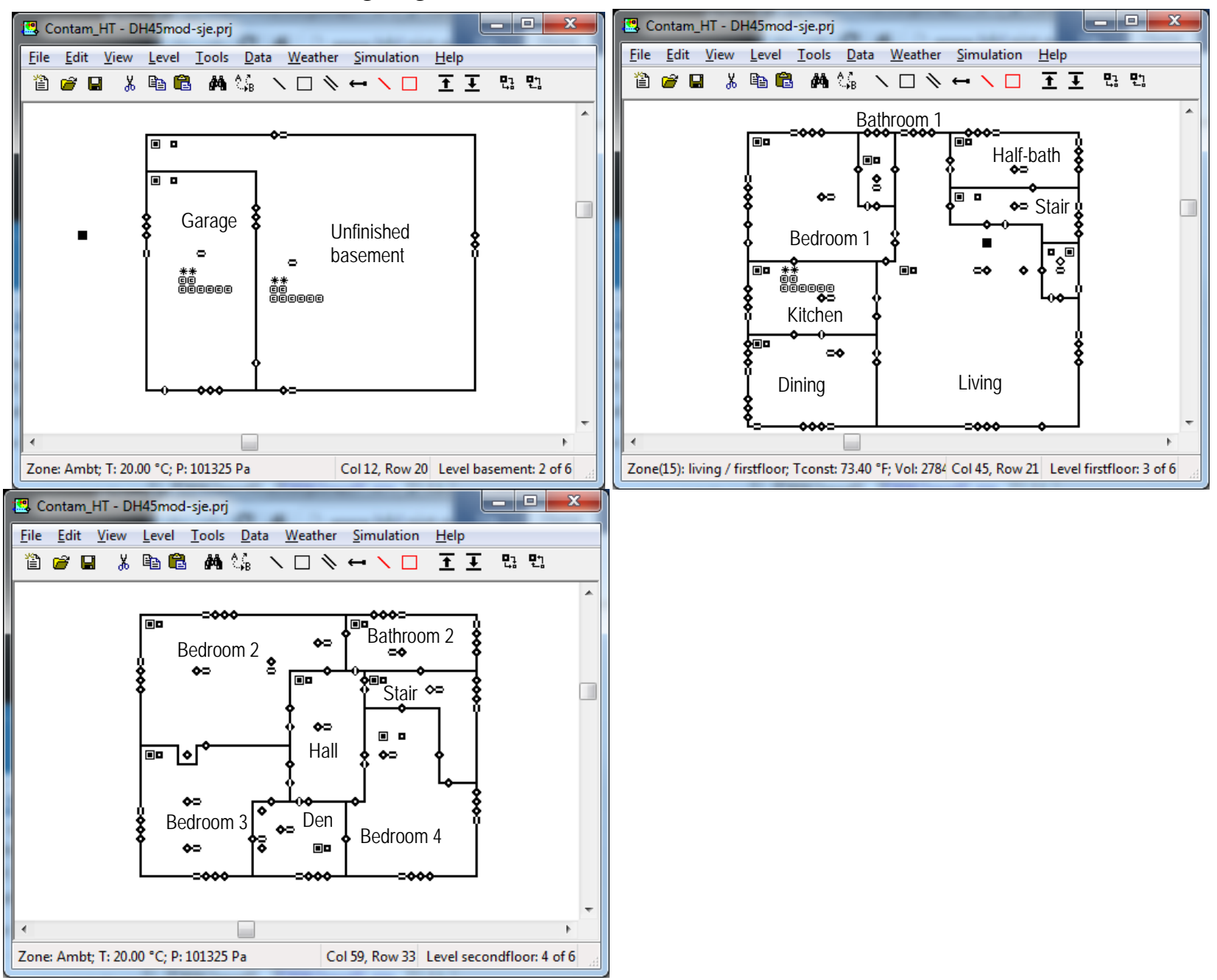

Figure 15 Floor plan of house DH-45mod as represented in CONTAM 
Figures 16 and 17 show individual zone $\mathrm{CO}$ concentration and COHb results, respectively, for the $\mathrm{C} 1$ source and reduced rate sources located in the garage of house DH-45mod on January $1^{\text {st }}$. The peak CO concentrations resulting from the C1 baseline source reached around $17,000 \mu \mathrm{L} / \mathrm{L}$ in the source zone, over $14,000 \mu \mathrm{L} / \mathrm{L}$ in the adjacent unfinished basement zone and from around $8,000 \mu \mathrm{L} / \mathrm{L}$ to $10,000 \mu \mathrm{L} / \mathrm{L}$ in the remaining non-source zones. Reductions in peak concentrations for the reduced rates of $50 \mathrm{~g} / \mathrm{h}$ to $1000 \mathrm{~g} / \mathrm{h}$, compared to the baseline C1 source peaks, were similar to those seen for the MH1mod cases and ranged from over $40 \%$ to well over $90 \%$. As with many of the MH1mod cases, the COHb shown in Figure 17 exceeded $40 \%$ in all zones for most of the source strengths, but remained below $40 \%$ in all non-source zones for just the $50 \mathrm{~g} / \mathrm{h}$ source. However, COHb generally increased more gradually in the $1^{\text {st }}$ and $2^{\text {nd }}$ floor zones since the source was in the garage on the basement level.

Figures 18 and 19 show individual zone CO concentration and COHb results, respectively, for the C1 source and reduced rate sources located in the garage of house DH45-mod on July $25^{\text {th }}$. As with the MH1mod cases, the warmer temperatures on July $25^{\text {th }}$ result in significantly higher CO concentrations in the source zone than on January $1^{\text {st }}$ (results in Figure 16). However, the results for the $1^{\text {st }}$ and $2^{\text {nd }}$ floor zones are much different on July $25^{\text {th }}$, as the $1^{\text {st }}$ floor concentrations are somewhat lower and the $2^{\text {nd }}$ floor concentrations are significantly lower compared to January $1^{\text {st }}$. The warmer outdoor air reduces the flow of air from the basement up to the $1^{\text {st }}$ and $2^{\text {nd }}$ floors due to a smaller indoor to outdoor temperature difference. However, the reductions in peak concentrations for the reduced sources are still in a range of over $40 \%$ to over $90 \%$ compared to the baseline C1 source. As seen in Figure 19, the COHb results were also quite different on July $25^{\text {th }}$ compared to January $1^{\text {st }}$, with somewhat lower values for the $1^{\text {st }}$ floor zones and significantly lower values for the $2^{\text {nd }}$ floor zones, including a few zones that stayed below $40 \%$ for all source strengths. 


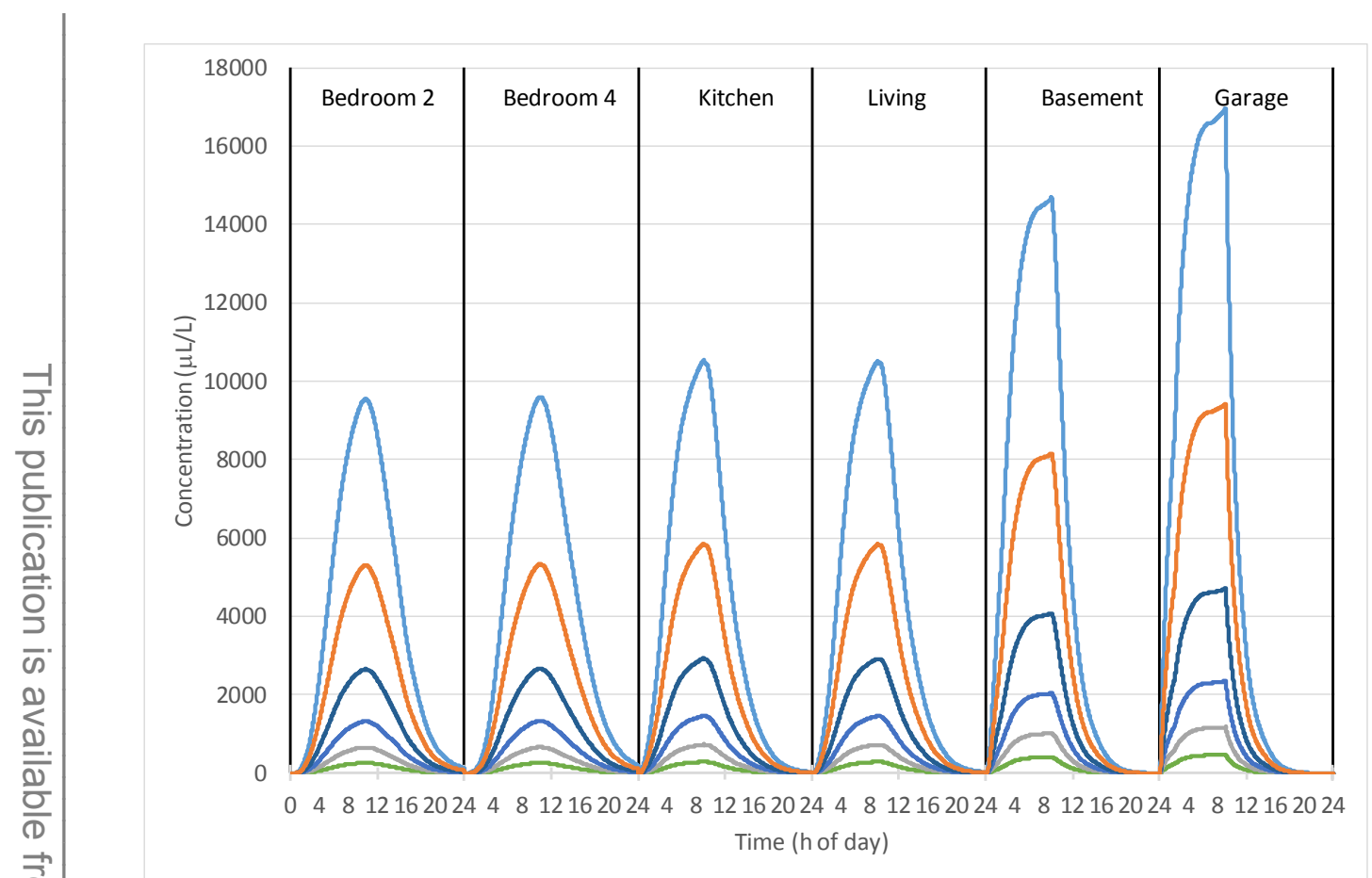

Figure 16 Individual zone transient CO results for the C1 source in Garage of DH-45mod on January $1^{\text {st }}$

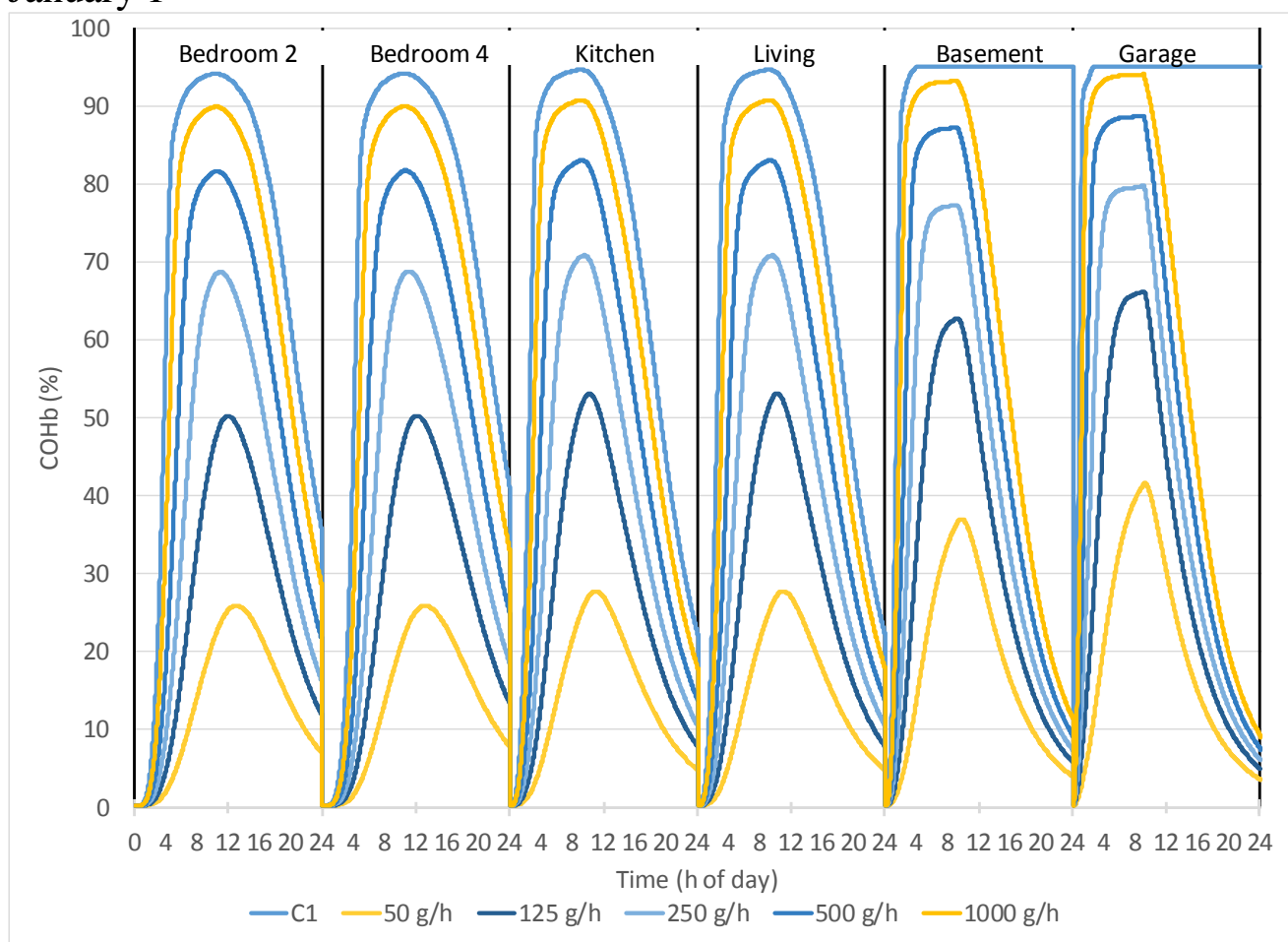

Figure 17 Individual zone transient $\mathrm{COHb}$ (with $\mathrm{RMV}=10 \mathrm{~L} / \mathrm{min}$ ) results for the $\mathrm{C} 1$ source in Garage of DH-45mod on January $1^{\text {st }}$ 


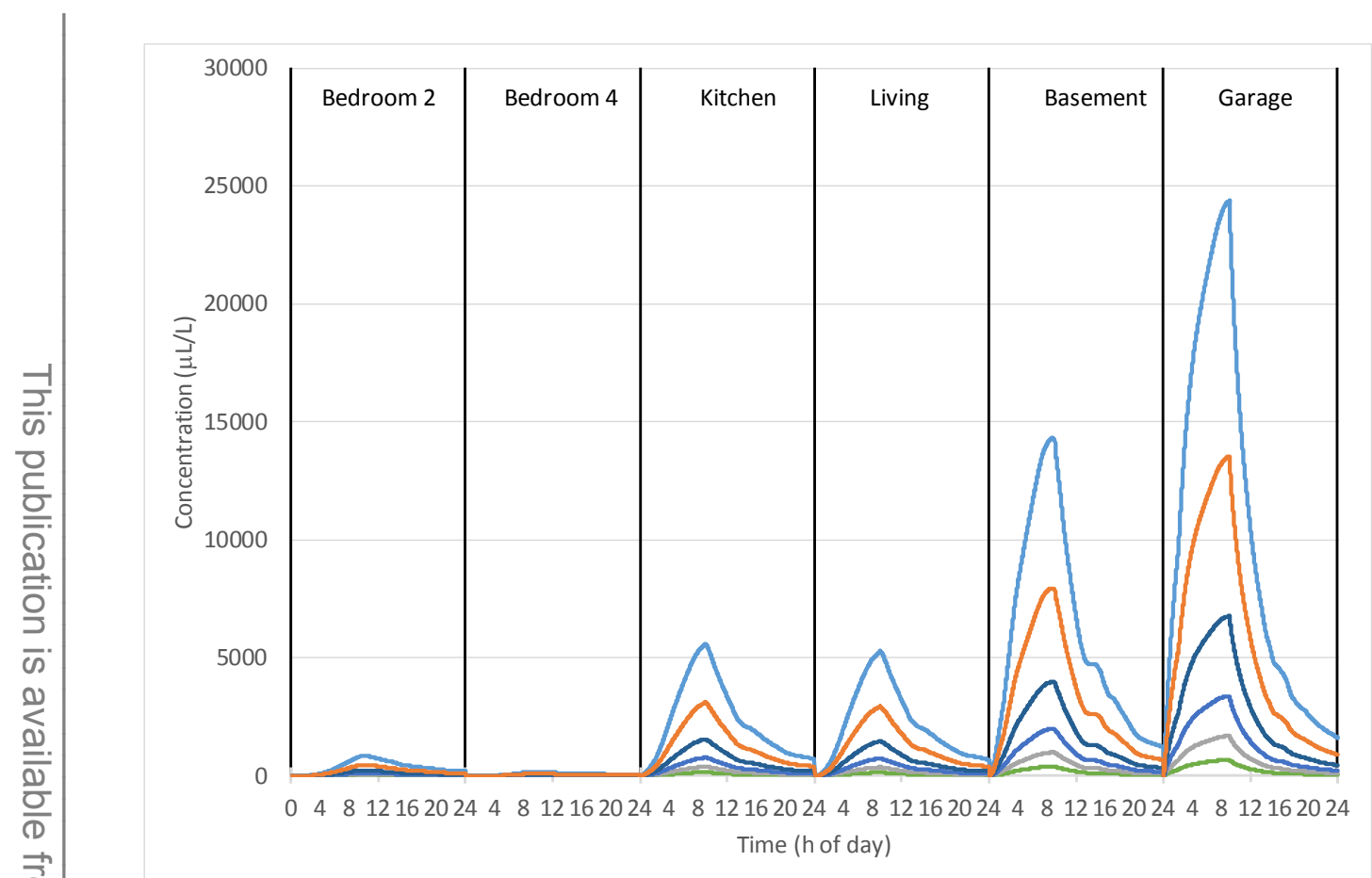

$-\mathrm{C} 1-50 \mathrm{~g} / \mathrm{h}-125 \mathrm{~g} / \mathrm{h}-250 \mathrm{~g} / \mathrm{h}-500 \mathrm{~g} / \mathrm{h}-1000 \mathrm{~g} / \mathrm{h}$

Figure 18 Individual zone transient CO results for the C1 source in Garage of DH-45mod on July $25^{\text {th }}$

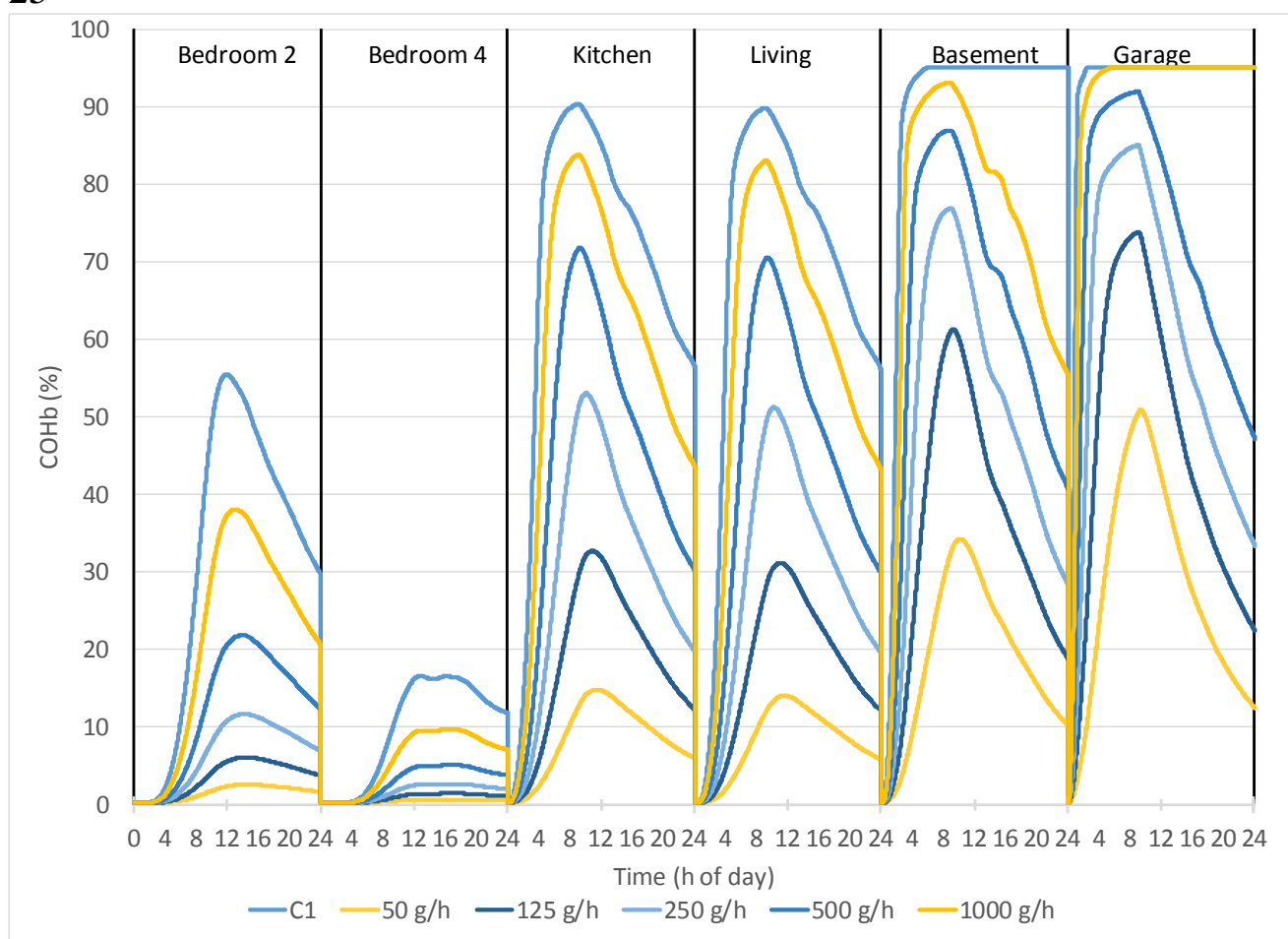

Figure 19 Individual zone transient $\mathrm{COHb}$ (with $\mathrm{RMV}=10 \mathrm{~L} / \mathrm{min}$ ) results for the $\mathrm{C} 1$ source in garage of $\mathrm{DH}-45 \mathrm{mod}$ on July $25^{\text {th }}$ 
Figures 20 and 21 show individual zone $\mathrm{CO}$ concentration and $\mathrm{COHb}$ results, respectively, for the C1 source (baseline $1800 \mathrm{~g} / \mathrm{h}$ ) and reduced rate sources located in the kitchen of house DH-45mod on January $1^{\text {st }}$. The peak CO concentrations resulting from the $\mathrm{C} 1$ baseline source reached around $11,000 \mu \mathrm{L} / \mathrm{L}$ in the source zone and around $10,000 \mu \mathrm{L} / \mathrm{L}$ in most of the $1^{\text {st }}$ and $2^{\text {nd }}$ floor non-source zones. Concentrations were near zero in the basement zones due to cold outdoor temperatures resulting in stack effect primarily causing flow upwards within the house. Reductions in peak concentrations for the reduced rates of $50 \mathrm{~g} / \mathrm{h}$ to $1000 \mathrm{~g} / \mathrm{h}$, compared to the baseline C1 source peaks, were similar to those seen for other cases and ranged from over $40 \%$ to well over $90 \%$. The COHb shown in Figure 21 exceeded $40 \%$ in nearly all zones for most of the source strengths but remained below $40 \%$ in all non-source zones for just the $50 \mathrm{~g} / \mathrm{h}$ source. However, $\mathrm{COHb}$ stayed well below $10 \%$ on the basement level.

Figures 22 and 23 show individual zone $\mathrm{CO}$ concentration and $\mathrm{COHb}$ results, respectively, for the C1 source and reduced rate sources located in the kitchen of house DH-45mod on July $25^{\text {th }}$. As with the garage source in Figure 18, the warm ambient temperatures on July $25^{\text {th }}$ result in significant variations in $\mathrm{CO}$ concentrations, depending primarily on the floor of the house. The peak CO concentrations resulting from the C1 baseline source reached over 25,000 $\mu \mathrm{L} / \mathrm{L}$ in the source zone and most other $1^{\text {st }}$ floor zones (well-connected due to fully open doorways), between $15,000 \mu \mathrm{L} / \mathrm{L}$ and $20,000 \mu \mathrm{L} / \mathrm{L}$ in the $2^{\text {nd }}$ floor zones, and at or below $5,000 \mu \mathrm{L} / \mathrm{L}$ in the basement zones. Once again, the reductions in peak concentrations for the reduced sources are in a range of over $40 \%$ to over $90 \%$ compared to the baseline C1 source. As seen in Figure 23, the COHb results were also quite different on July $25^{\text {th }}$ compared to January $1^{\text {st }}$, with somewhat lower values and slower increases for the $2^{\text {nd }}$ floor zones and significantly lower values and much slower increases for the basement zones. 


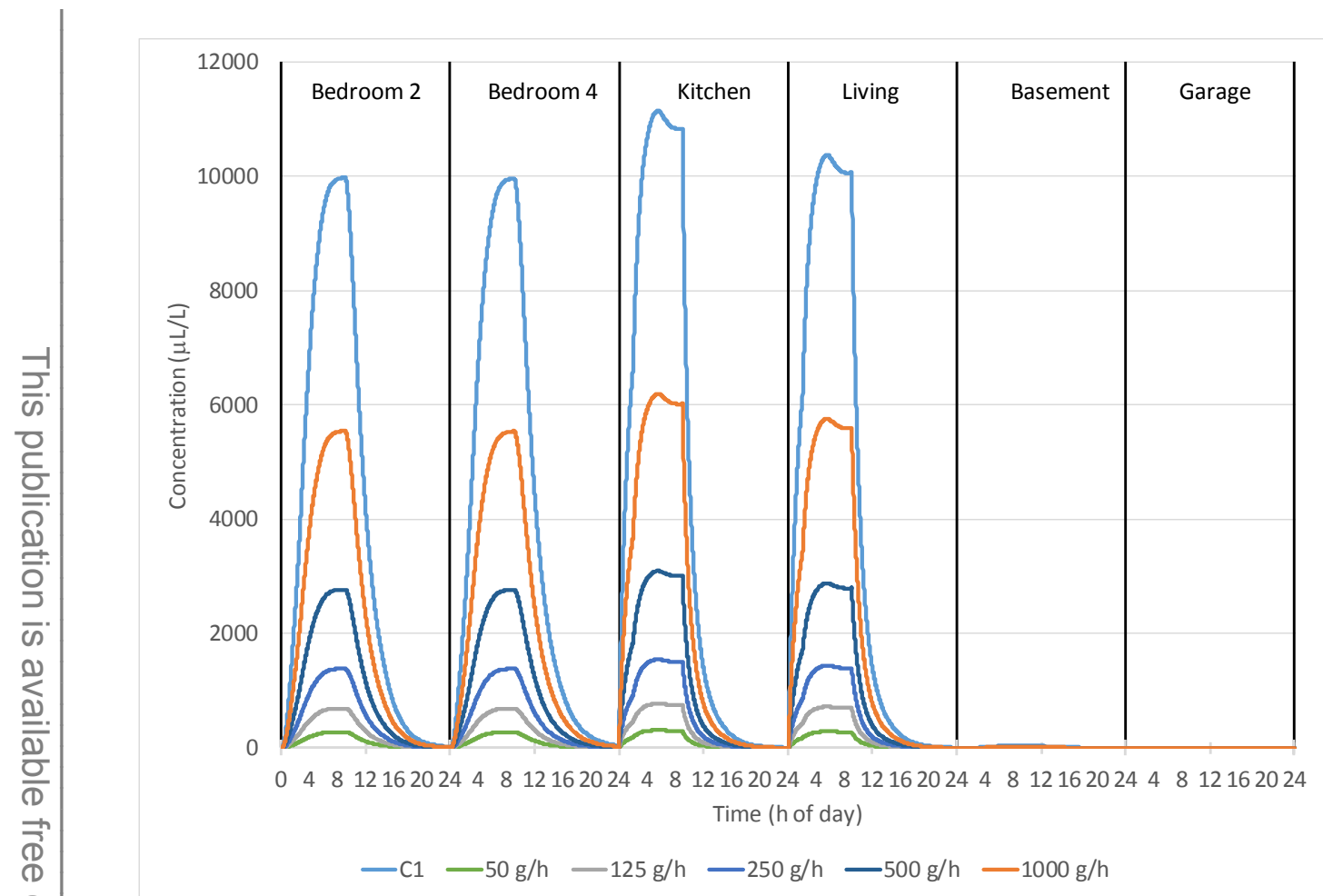

Figure 20 Individual zone transient CO results for the C1 source in Kitchen of DH-45mod on January $1^{\text {st }}$

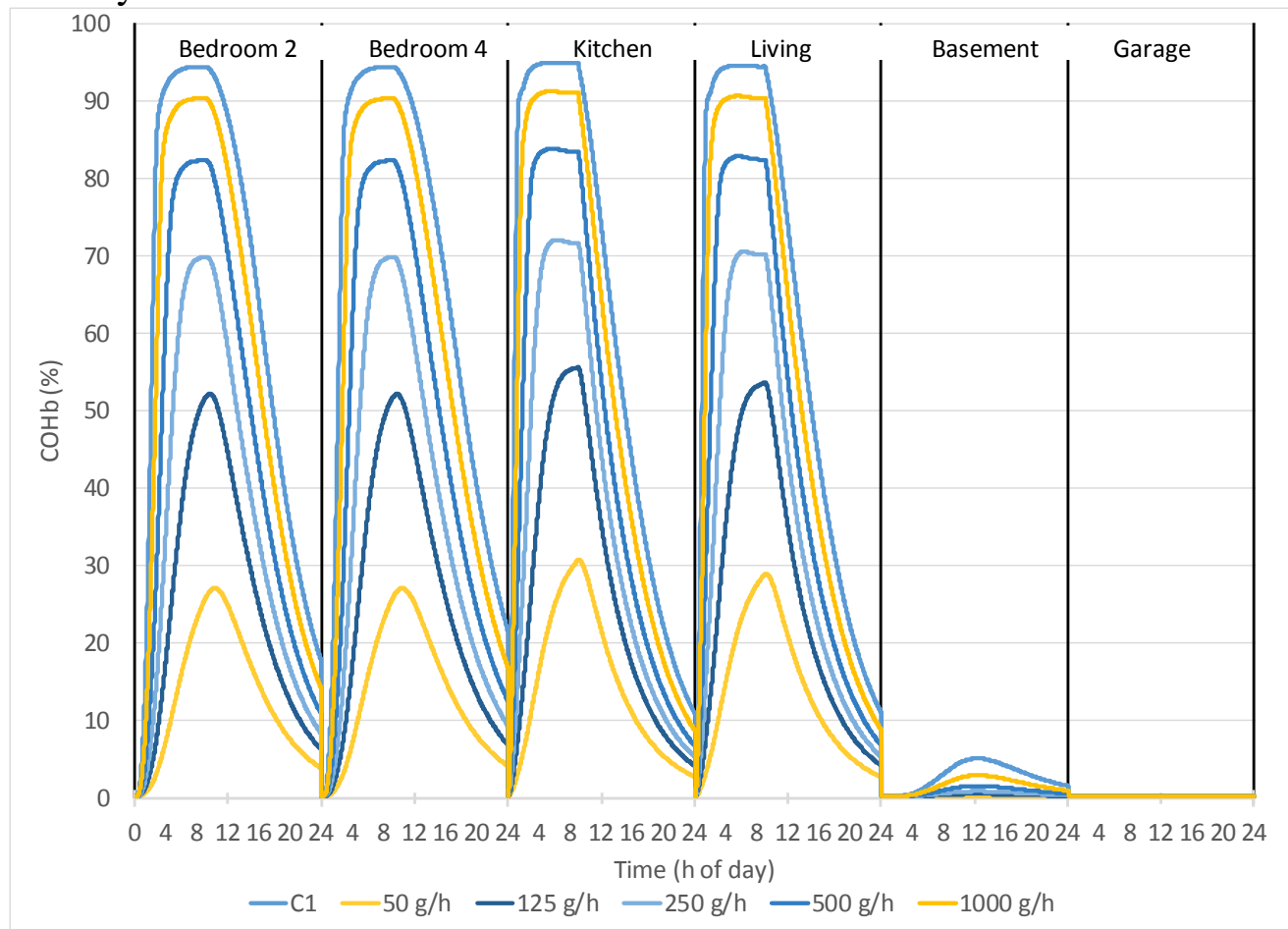

Figure 21 Individual zone transient $\mathrm{COHb}$ (with $\mathrm{RMV}=10 \mathrm{~L} / \mathrm{min}$ ) results for the $\mathrm{C} 1$ source in Kitchen of DH-45mod on January $1^{\text {st }}$ 


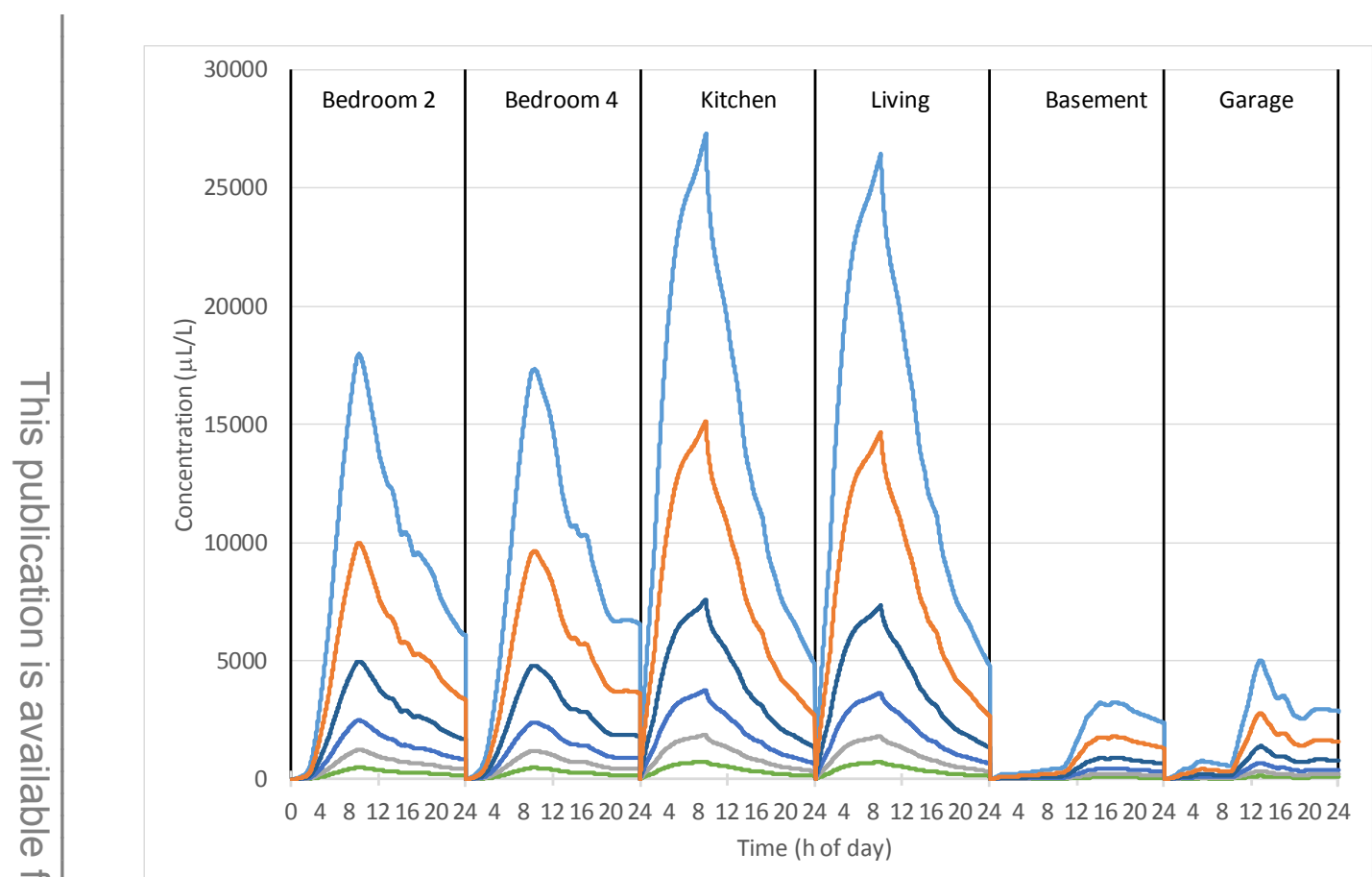

$-\mathrm{C} 1-50 \mathrm{~g} / \mathrm{h}-125 \mathrm{~g} / \mathrm{h}-250 \mathrm{~g} / \mathrm{h}-500 \mathrm{~g} / \mathrm{h}-1000 \mathrm{~g} / \mathrm{h}$

Figure 22 Individual zone transient CO results for the C1 source in Kitchen of DH-45mod on July $25^{\text {th }}$

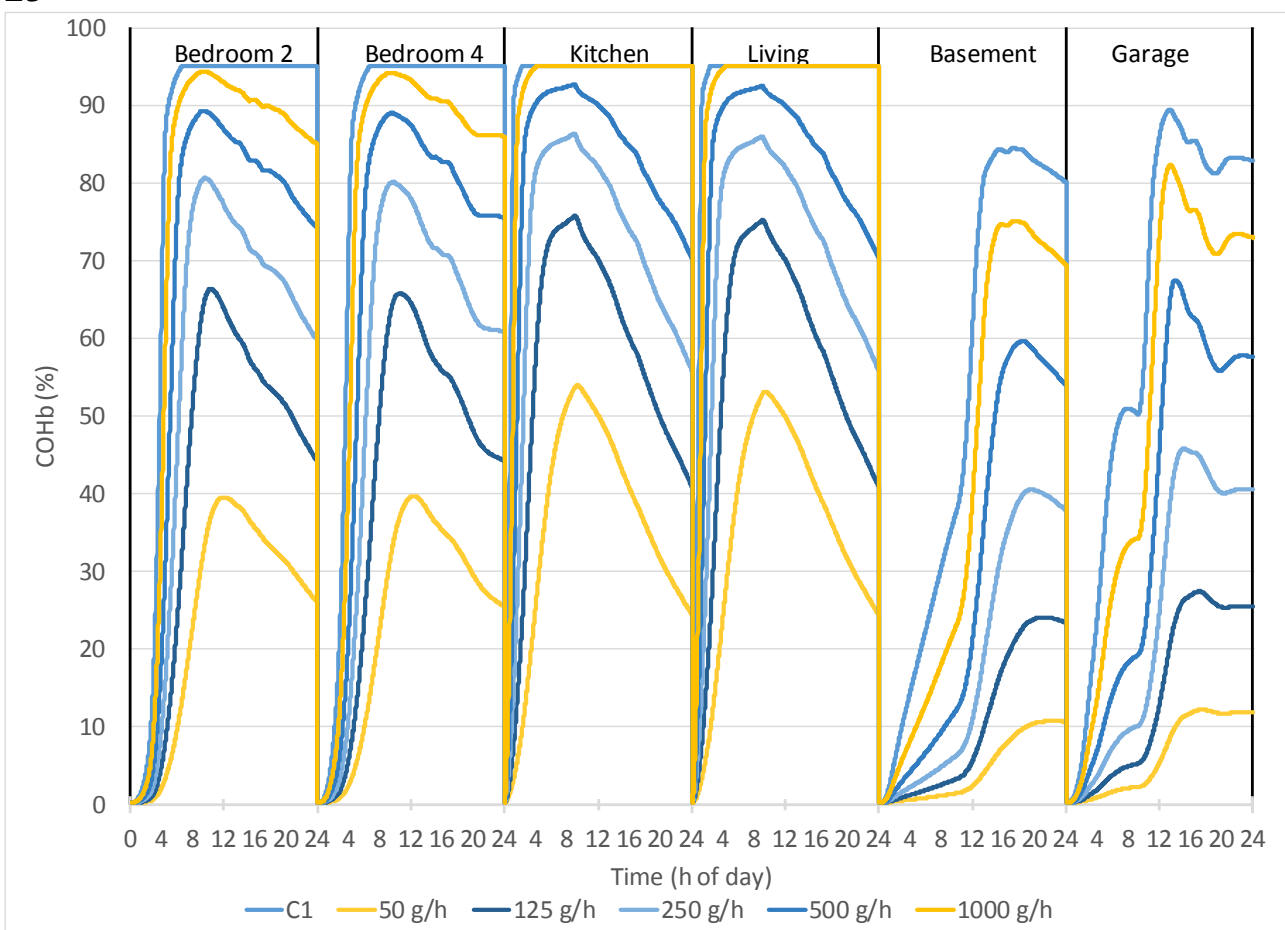

Figure 23 Individual zone transient $\mathrm{COHb}$ (with $\mathrm{RMV}=10 \mathrm{~L} / \mathrm{min}$ ) results for the $\mathrm{C} 1$ source in Kitchen of DH-45mod on July $25^{\text {th }}$ 


\subsection{Sample results for a large 2-story detached house with garage (DH-12)}

This section presents simulation results for detached house DH-12 from the NIST suite of homes. Figure 24 shows the floorplan of DH-12 as represented in the CONTAM Sketchpad. DH-12 has $276 \mathrm{~m}^{2}$ of floor area with a bedroom, den, family room and bathroom in the basement, a kitchen, dining room, living room, bathroom and attached garage on the first floor and three bedrooms and a bathroom on the second floor. DH-12 was modeled with generators located in the kitchen, bedroom 4 in the basement and the garage.
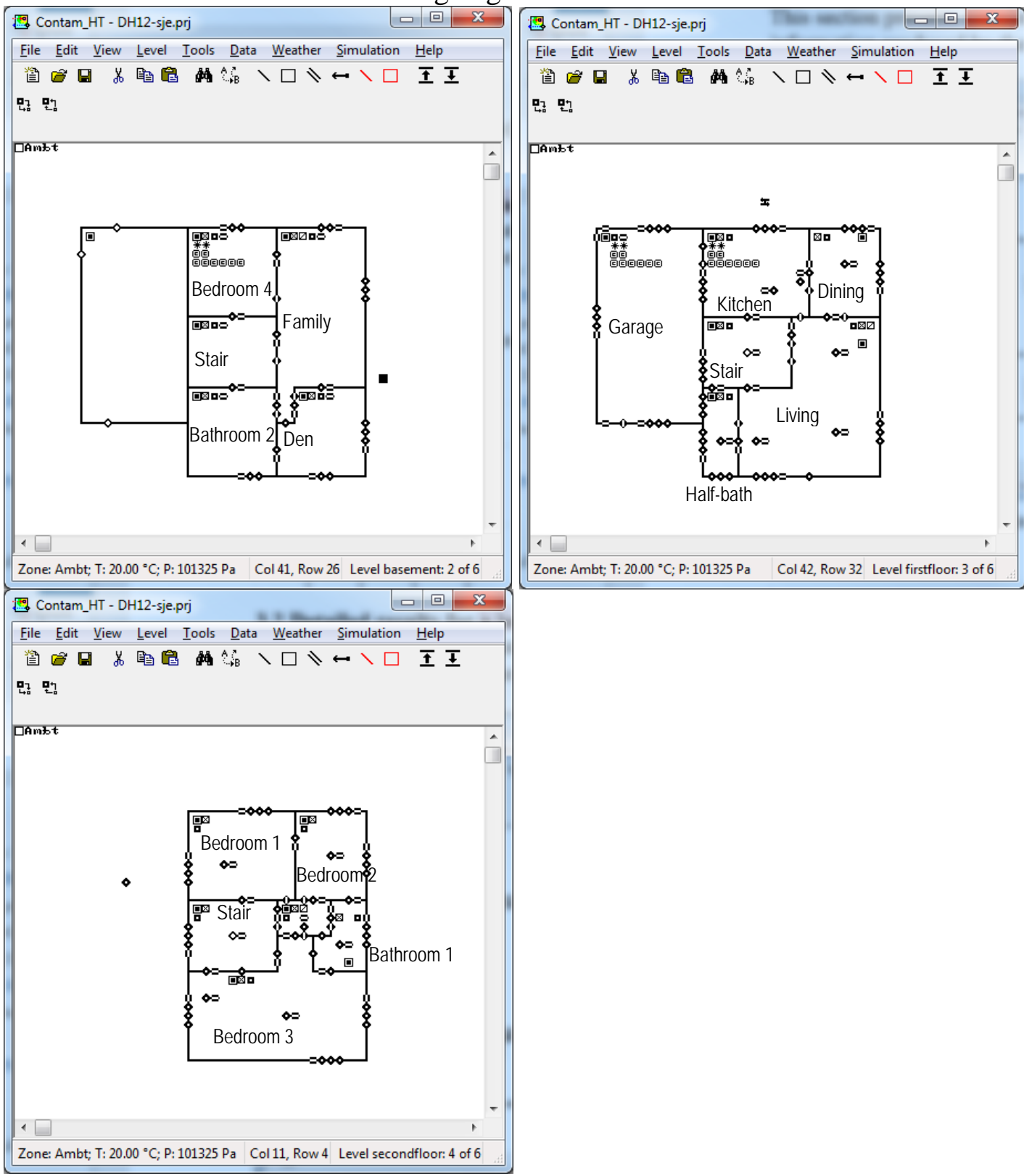

Figure 24 Floor plan of house DH-12 as represented in CONTAM 
As with the DH-45mod results in Figures 16 through 23, the results for DH-12 shown in Figures 25 through 32 show significant variation by level of the house depending on the source location and weather. Figures 25 and 26 show individual zone CO concentration and COHb results, respectively, for the $\mathrm{C} 2$ single source (baseline $4700 \mathrm{~g} / \mathrm{h}$ ) and reduced rate sources located in the garage of house $\mathrm{DH}-12$ on January $1^{\text {st }}$. The peak CO concentrations resulting from the C2 single baseline source reached around $20,000 \mu \mathrm{L} / \mathrm{L}$ in the source zone, around 3,000 $\mu \mathrm{L} / \mathrm{L}$ to $6,000 \mu \mathrm{L} / \mathrm{L}$ in the non-source zones on the $1^{\text {st }}$ and $2^{\text {nd }}$ floors, and remained below $400 \mu \mathrm{L} / \mathrm{L}$ in the basement zones. Reductions in peak concentrations for the reduced rates of $50 \mathrm{~g} / \mathrm{h}$ to $2000 \mathrm{~g} / \mathrm{h}$, compared to the baseline C2 single source peaks, were similar to those seen for the previous cases and ranged from over $50 \%$ to well over $90 \%$. Unlike previous cases, the COHb shown in Figure 26 remained below $40 \%$ in many non-source zones for reduced source strengths up to $500 \mathrm{~g} / \mathrm{h}$ and below $40 \%$ in the basement zones for all source strengths.

Figures 27 and 28 show individual zone CO concentration and COHb results, respectively, for the C2 single source and reduced rate sources located in the garage of house DH-12 on July $25^{\text {th }}$. For this case, the peak CO concentration reached around 23,000 $\mu \mathrm{L} / \mathrm{L}$ in the garage but stayed below $2,000 \mu \mathrm{L} / \mathrm{L}$ in the other $1^{\text {st }}$ floor zones, with little CO transport to the basement and none to the $2^{\text {nd }}$ floor zones for this case. The reductions in peak concentrations for the reduced sources are still in a range of over $50 \%$ to well over $90 \%$ compared to the baseline C2 single source. As seen in Figure 28, the COHb remained below $40 \%$ for all sources strengths up to $1000 \mathrm{~g} / \mathrm{h}$ in all $1^{\text {st }}$ floor non-source zones and below $20 \%$ for all source strengths in the basement and $2^{\text {nd }}$ floor zones. 


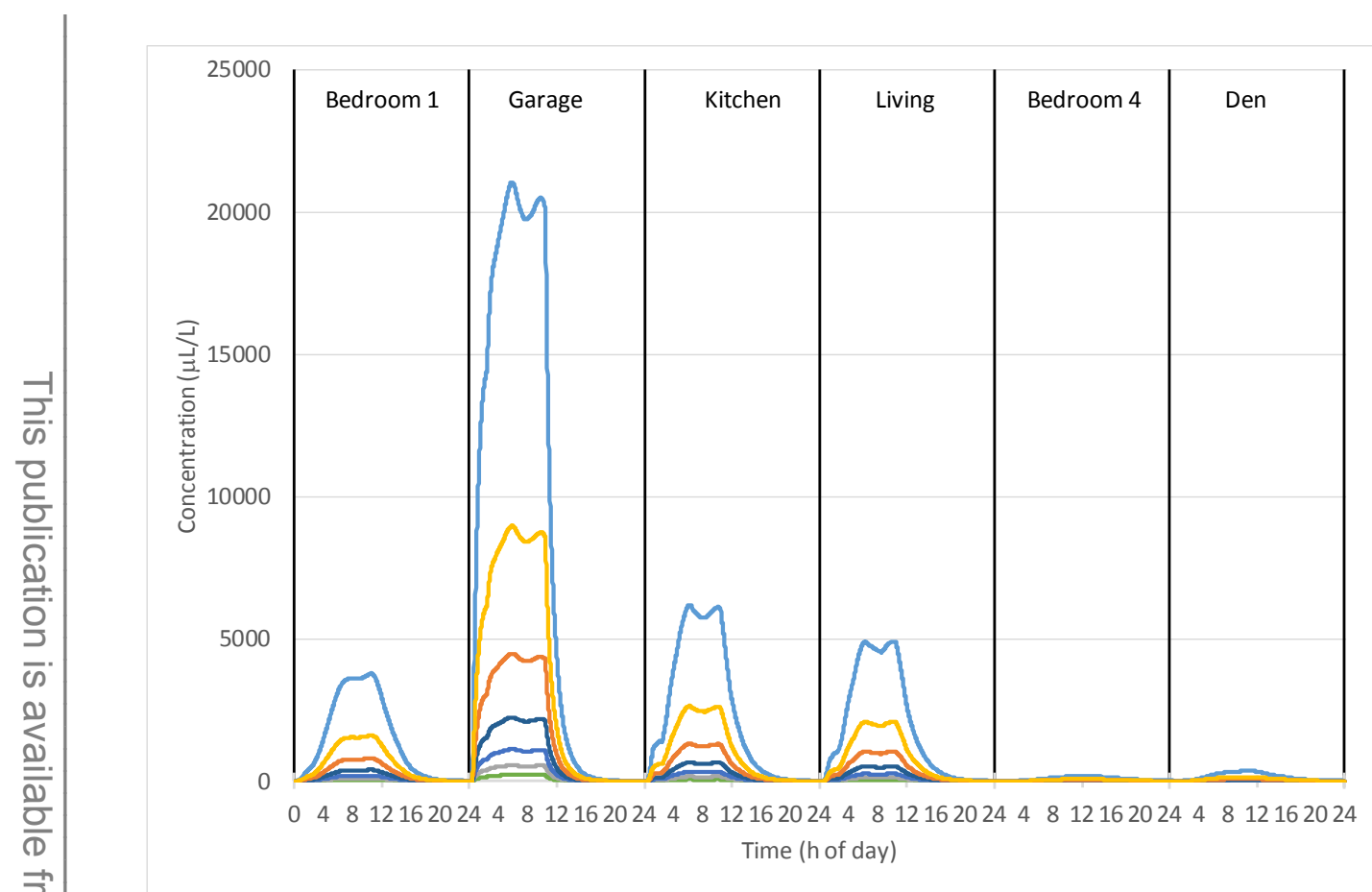

$-\mathrm{C} 2$ single $-50 \mathrm{~g} / \mathrm{h}-125 \mathrm{~g} / \mathrm{h}-250 \mathrm{~g} / \mathrm{h}-500 \mathrm{~g} / \mathrm{h}-1000 \mathrm{~g} / \mathrm{h}-2000 \mathrm{~g} / \mathrm{h}$

Figure 25 Individual zone transient CO results for the C2 single source in Garage of DH12 on January $1^{\text {st }}$

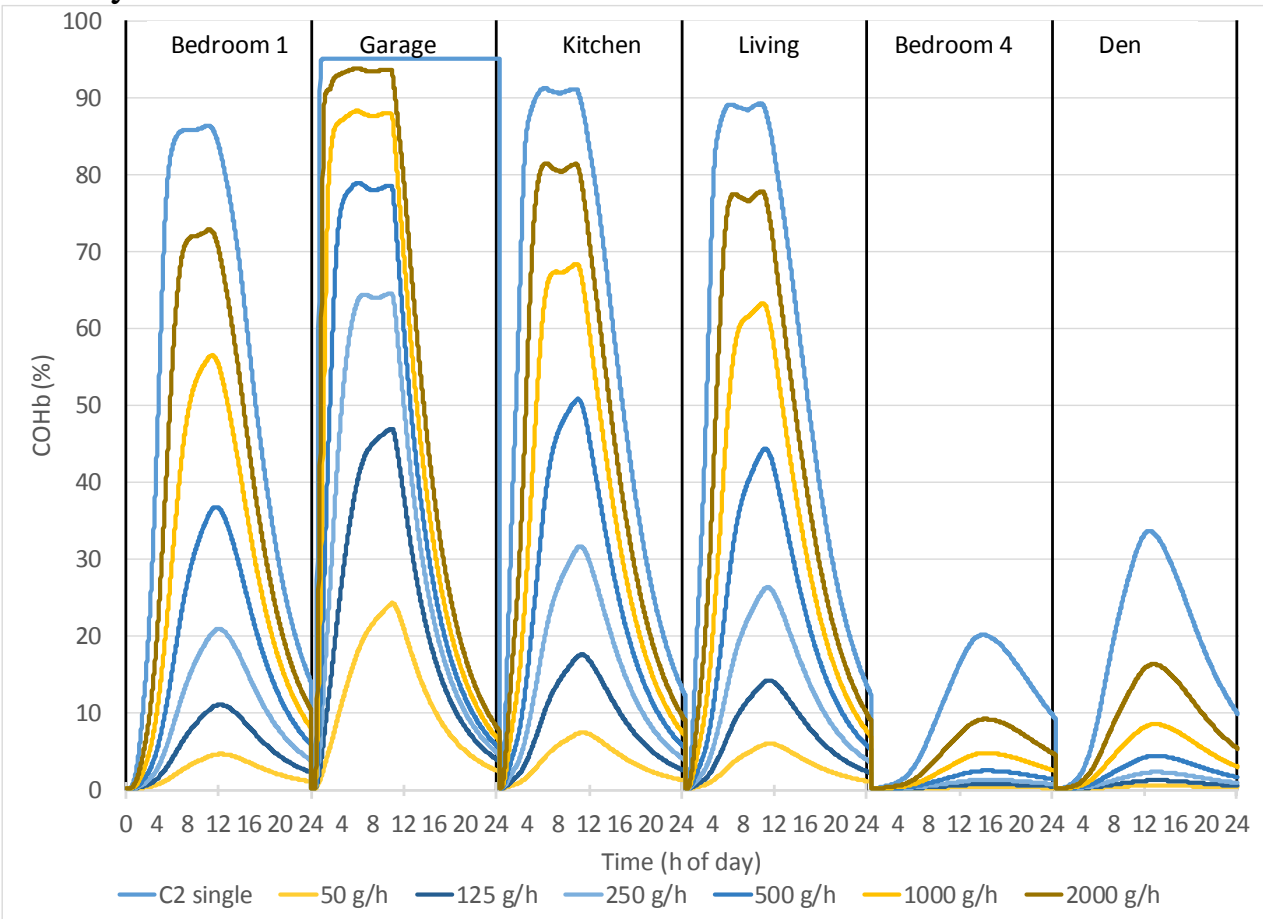

Figure 26 Individual zone transient $\mathrm{COHb}$ (with $\mathrm{RMV}=10 \mathrm{~L} / \mathrm{min}$ ) results for the $\mathrm{C} 2$ single source in Garage of DH12 on January $1^{\text {st }}$ 


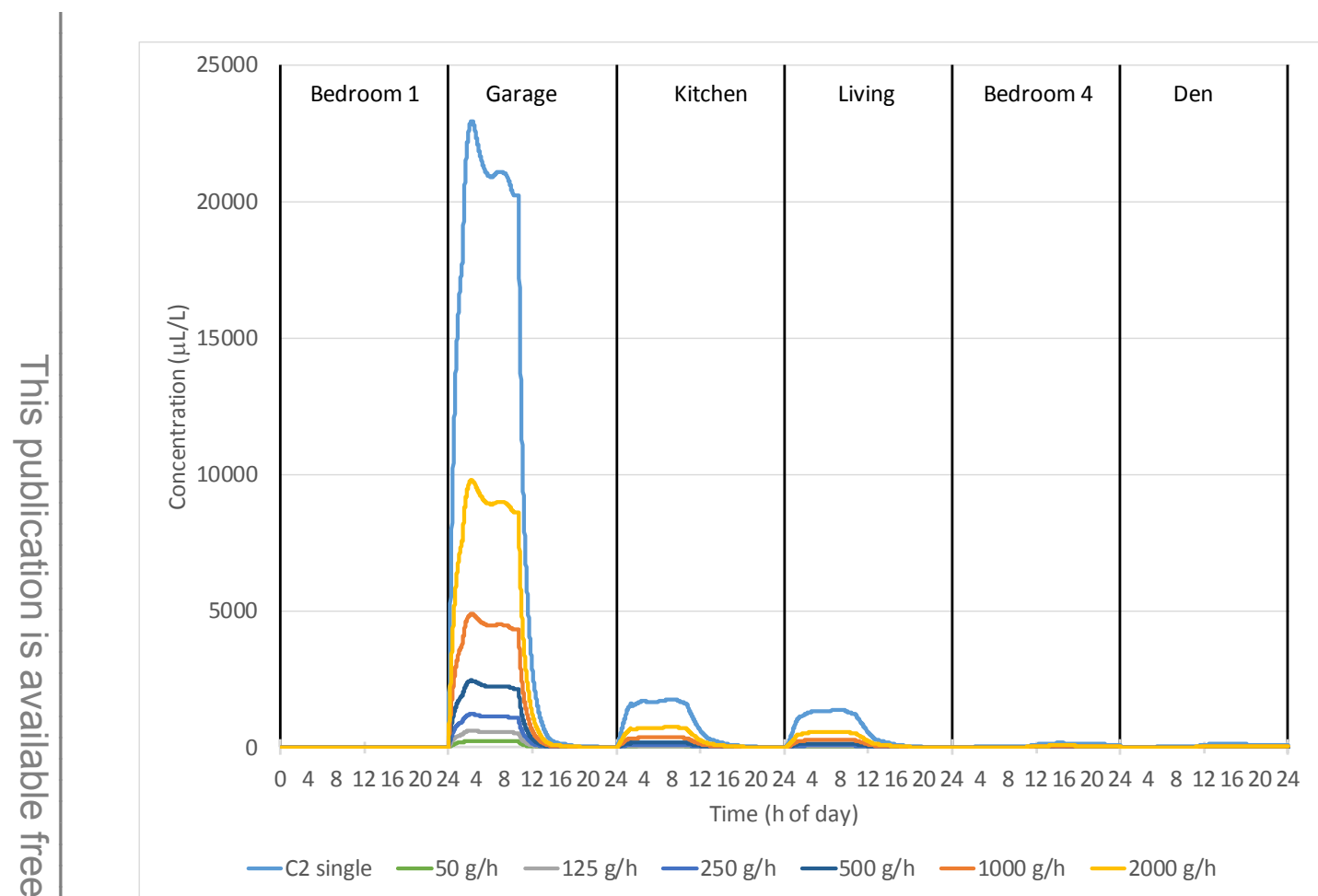

Figure 27 Individual zone transient CO results for the C2 single source in Garage of DH12 on July $25^{\text {th }}$

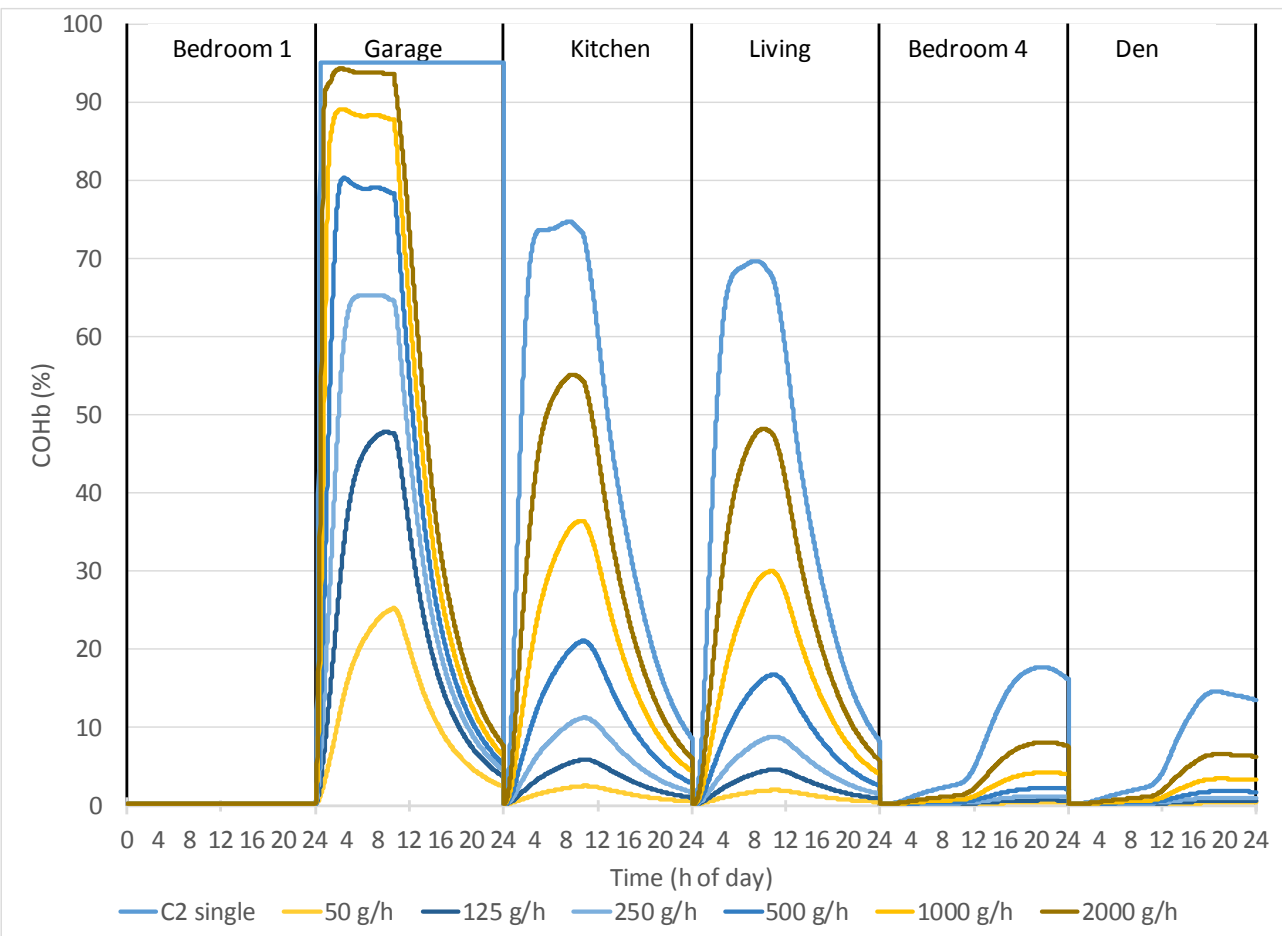

Figure 28 Individual zone transient $\mathrm{COHb}$ (with $\mathrm{RMV}=10 \mathrm{~L} / \mathrm{min}$ ) results for the $\mathrm{C} 2$ single source in Garage of DH12 on July $25^{\text {th }}$ 
Figures 29 and 30 show individual zone $\mathrm{CO}$ concentration and $\mathrm{COHb}$ results, respectively, for the C2 single baseline source and reduced rate sources located in bedroom 4 in the basement of house DH-12 on January $1^{\text {st }}$. Due to the relative lack of outdoor air infiltration into the basement, the peak CO concentrations resulting from the C2 single source reached 50,000 $\mu \mathrm{L} / \mathrm{L}$ in the source zone, over 30,000 $\mu \mathrm{L} / \mathrm{L}$ in the adjacent family room, and $15,000 \mu \mathrm{L} / \mathrm{L}$ to $20,000 \mu \mathrm{L} / \mathrm{L}$ in most of the other zones (not including the garage). Reductions in peak concentrations for the reduced rates of $50 \mathrm{~g} / \mathrm{h}$ to $2000 \mathrm{~g} / \mathrm{h}$ compared to the baseline C2 single source peaks once again ranged from over $50 \%$ to well over $90 \%$. The COHb shown in Figure 30 remained below $40 \%$ in the nonsource zones for only the $50 \mathrm{~g} / \mathrm{h}$ source, but reached or exceeded $40 \%$ in all house zones (not including the garage) for all other source strengths.

Figures 31 and 32 show individual zone $\mathrm{CO}$ concentration and $\mathrm{COHb}$ results, respectively, for the C2 single source and reduced rate sources located in bedroom 4 in the basement of house DH-12 on July $25^{\text {th }}$. For this case, the peak CO concentration for the C2 single source reached almost $100,000 \mu \mathrm{L} / \mathrm{L}$ in the garage, over $68,000 \mu \mathrm{L} / \mathrm{L}$ in the other basement zones and nearly $40,000 \mu \mathrm{L} / \mathrm{L}$ in the $1^{\text {st }}$ floor zones. CO concentrations were much lower in the $2^{\text {nd }}$ floor zones but still in the range of $1,000 \mu \mathrm{L} / \mathrm{L}$ to $5,000 \mu \mathrm{L} / \mathrm{L}$. The reductions in peak concentrations for the reduced sources again range from over $50 \%$ to well over $90 \%$ compared to the baseline C2 single source. As seen in Figure 32, the COHb exceeded $40 \%$ for all sources strengths in the basement zones, remained below $40 \%$ for just the $50 \mathrm{~g} / \mathrm{h}$ source in the $1^{\text {st }}$ floor zones, and remained near or below $40 \%$ for all sources up to $500 \mathrm{~g} / \mathrm{h}$ in all $2^{\text {nd }}$ floor zones. 


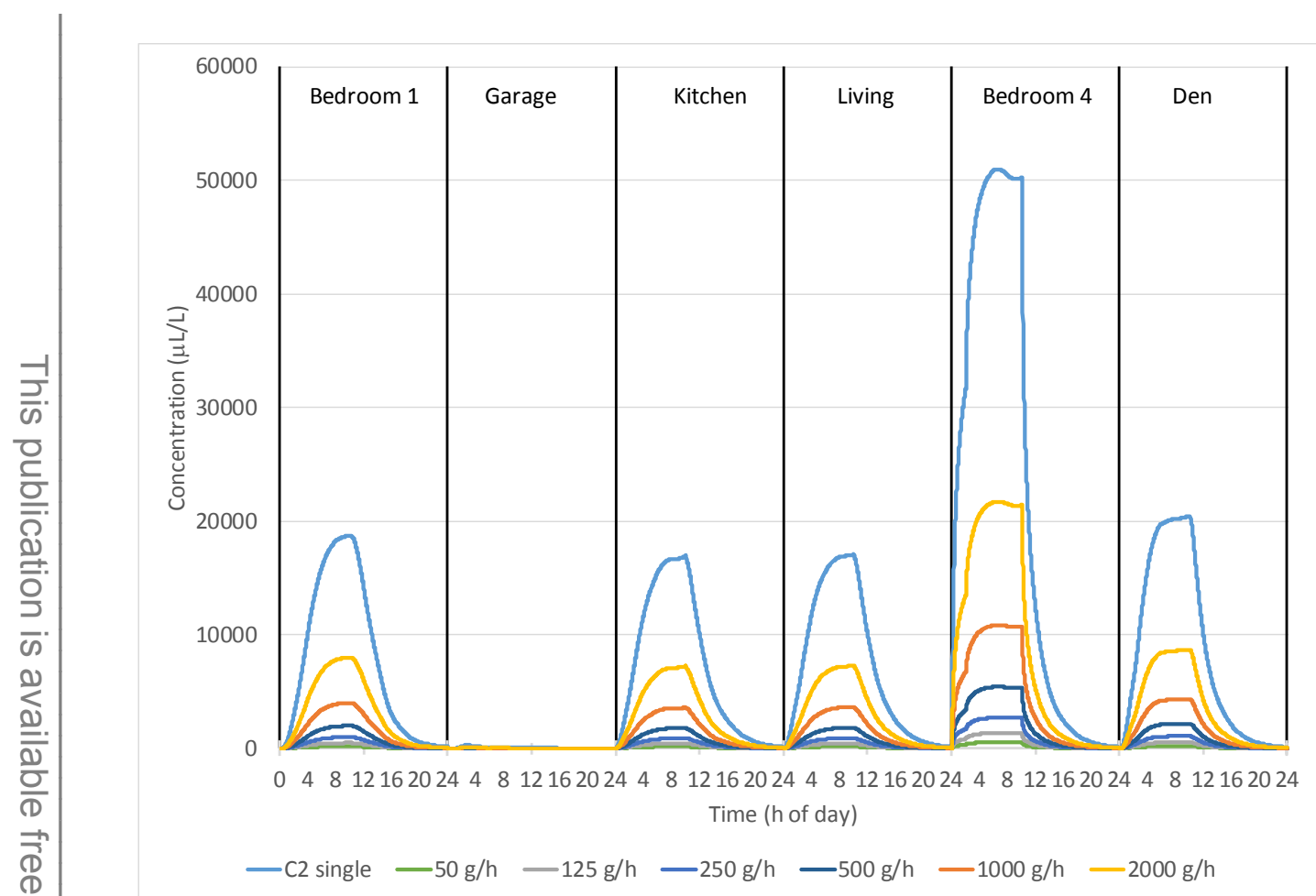

Figure 29 Individual zone transient CO results for the C2 single source in Bedroom 4 of DH12 on January $1^{\text {st }}$

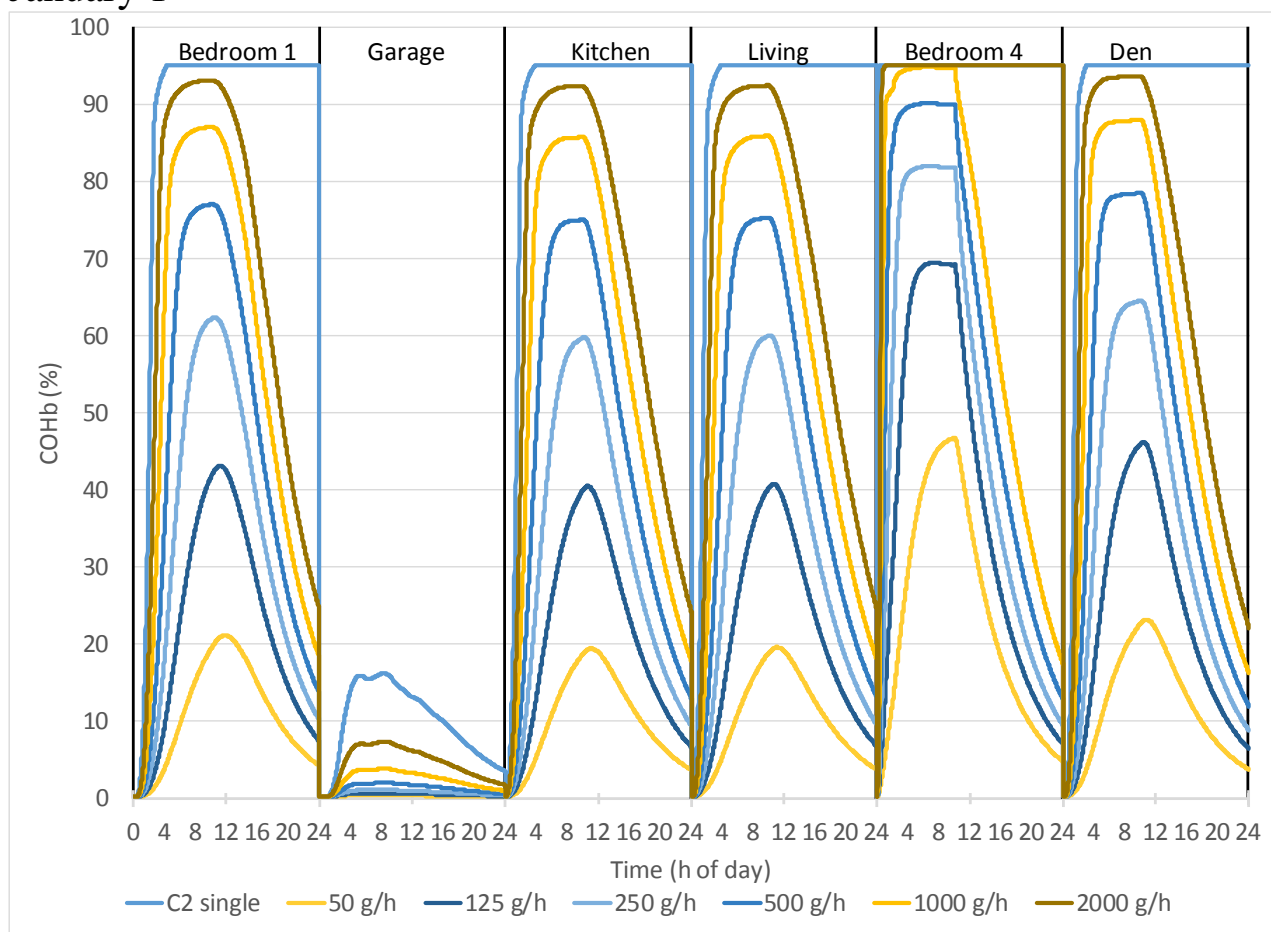

Figure 30 Individual zone transient $\mathrm{COHb}$ (with $\mathrm{RMV}=10 \mathrm{~L} / \mathrm{min}$ ) results for the $\mathrm{C} 2$ single source in Bedroom 4 of DH12 on January $1^{\text {st }}$ 


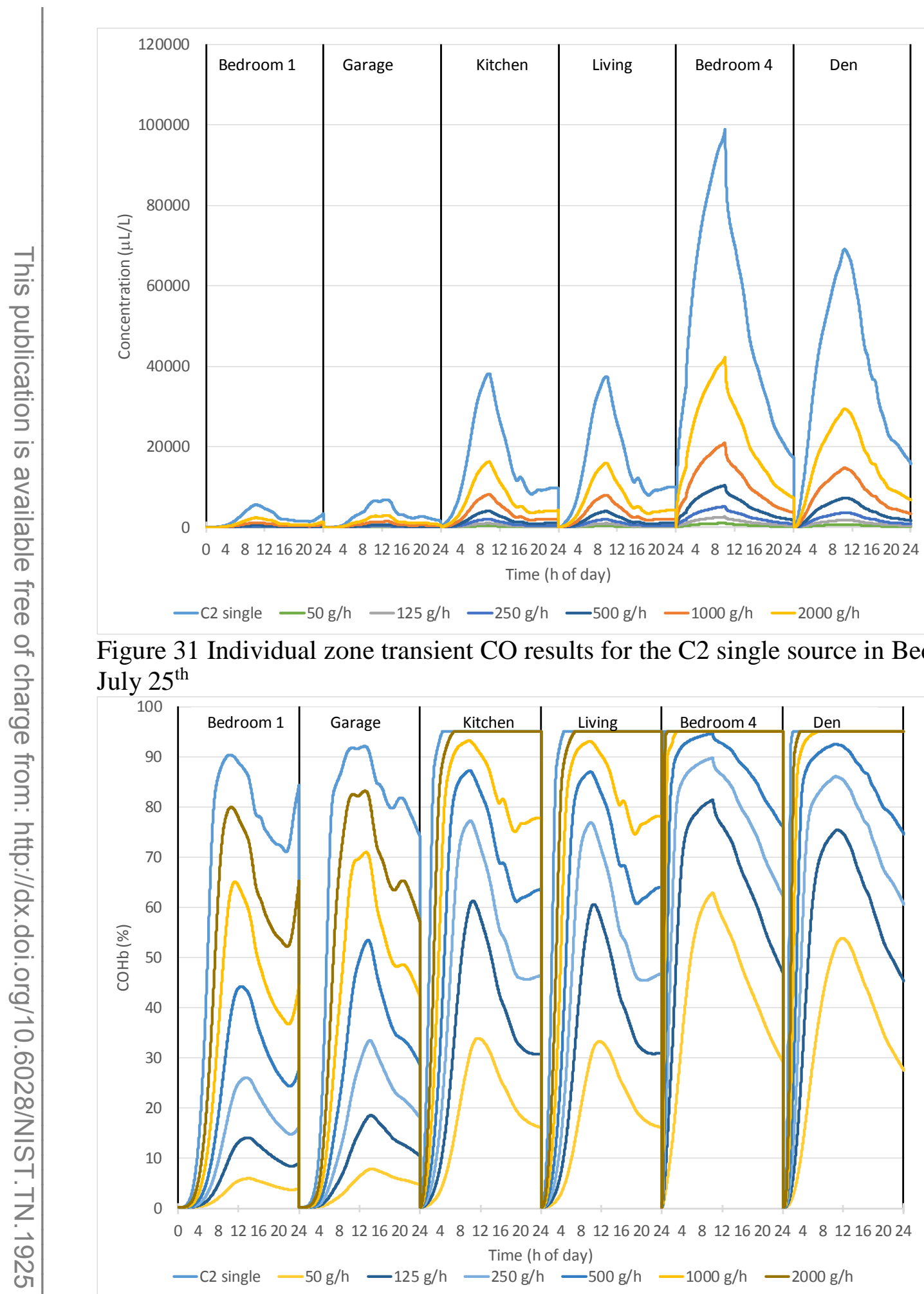

Figure 32 Individual zone transient $\mathrm{COHb}$ (with $\mathrm{RMV}=10 \mathrm{~L} / \mathrm{min}$ ) results for the $\mathrm{C} 2$ single source in Bedroom 4 of DH12 on July $25^{\text {th }}$ 


\subsection{Sample results for large garage with workshop (GAR3)}

This section presents sample results for the building GAR3, which was created for this project as a large two zone garage with $60.4 \mathrm{~m}^{2}$ of floor area including a separate workshop zone.

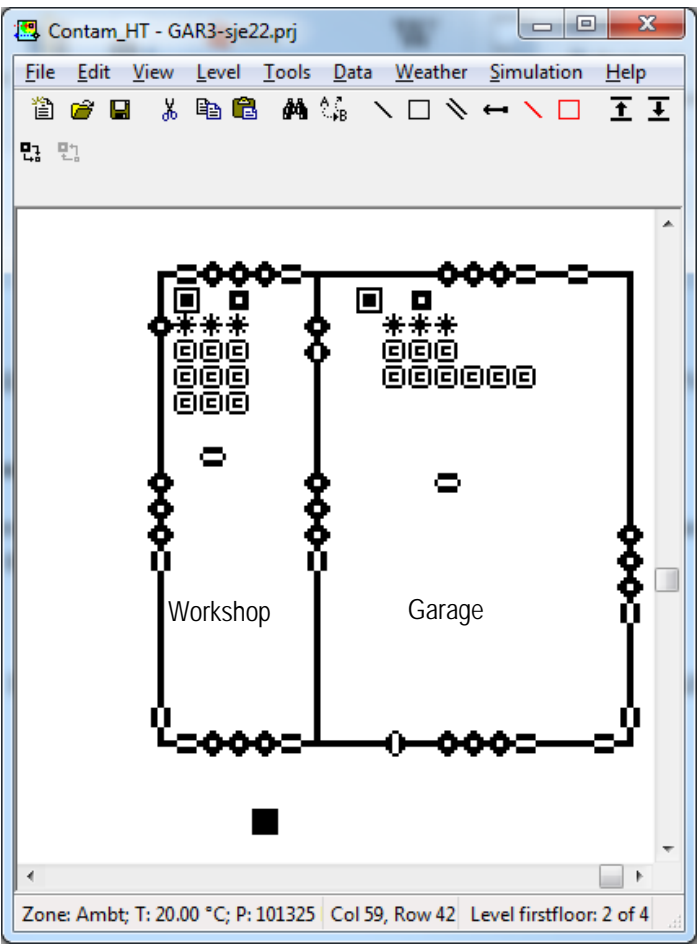

Figure 33 Floor plan of house GAR3 as represented in CONTAM

Figures 34 and 35 show individual zone $\mathrm{CO}$ concentration and $\mathrm{COHb}$ results, respectively, for the C2 twin baseline source $(9100 \mathrm{~g} / \mathrm{h}$ ) and reduced rate sources located in the garage zone of GAR3 on January $1^{\text {st }}$. The peak CO concentrations resulting from the C2 twin source reached almost $35,000 \mu \mathrm{L} / \mathrm{L}$ in the garage and over $12,000 \mu \mathrm{L} / \mathrm{L}$ in the workshop. Reductions in peak concentrations for the reduced rates of $50 \mathrm{~g} / \mathrm{h}$ to $2000 \mathrm{~g} / \mathrm{h}$, compared to the baseline C2 twin source, ranged from nearly $80 \%$ to well over $90 \%$. The COHb shown in Figure 35 remained at or below $40 \%$ in both zones for the $50 \mathrm{~g} / \mathrm{h}$ and $125 \mathrm{~g} / \mathrm{h}$ sources, but reached or exceeded $40 \%$ in both zones for all source strengths over $500 \mathrm{~g} / \mathrm{h}$. However, Figure 35 also shows that the $\mathrm{COHb}$ increases more slowly in both zones as the source strength drops.

Figures 36 and 37 show individual zone $\mathrm{CO}$ concentration and $\mathrm{COHb}$ results, respectively, for the C2 twin source and reduced rate sources located in the garage zone of GAR3 on July $25^{\text {th }}$. The results for this case are quite similar to the January $1^{\text {st }}$ results, with somewhat higher CO concentrations and $\mathrm{COHb}$ due to the lower air change rate during the warmer weather. 


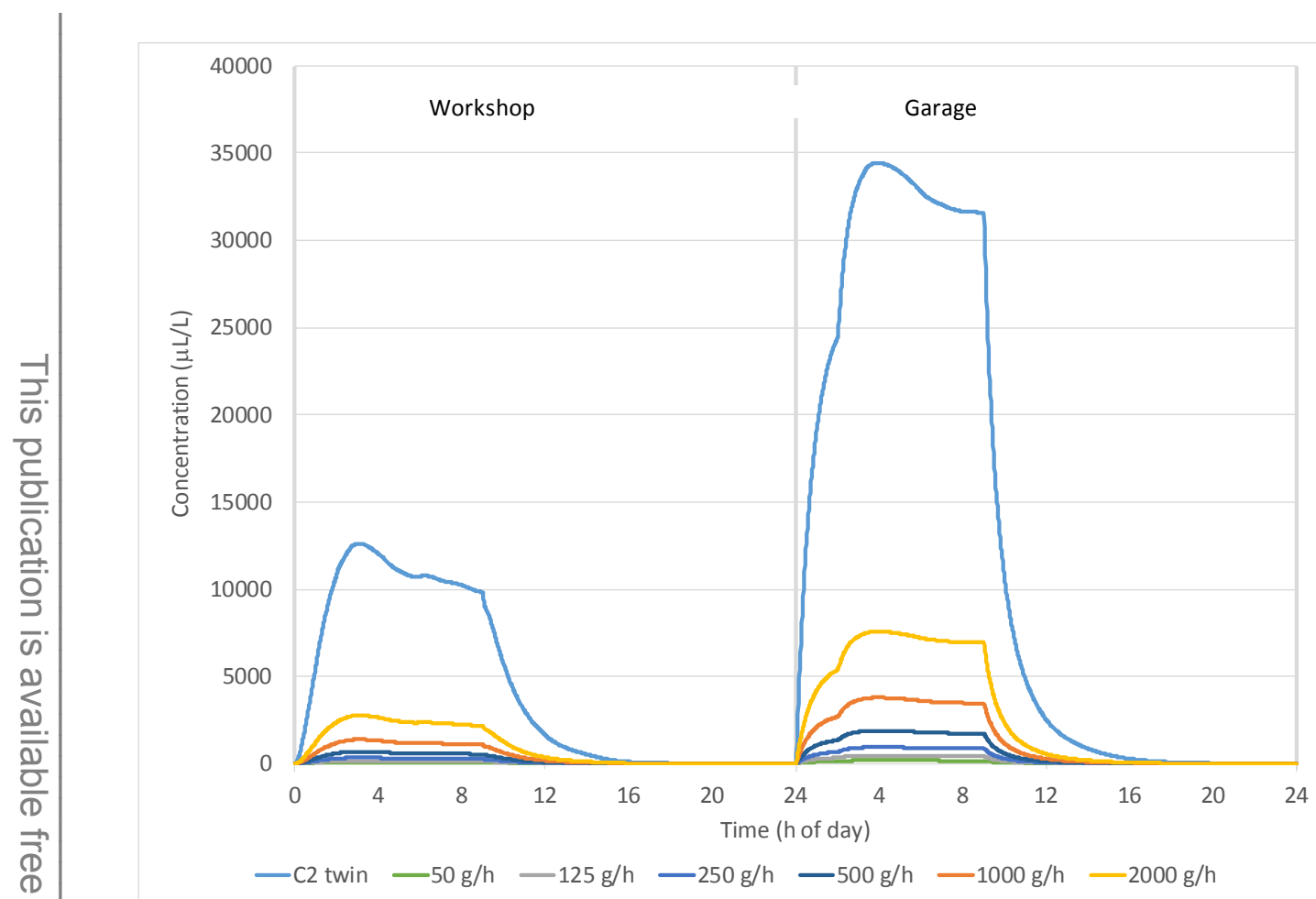

Figure 34 Individual zone transient CO results for the C2 twin source in the Garage zone of GAR3 on January $1^{\text {st }}$

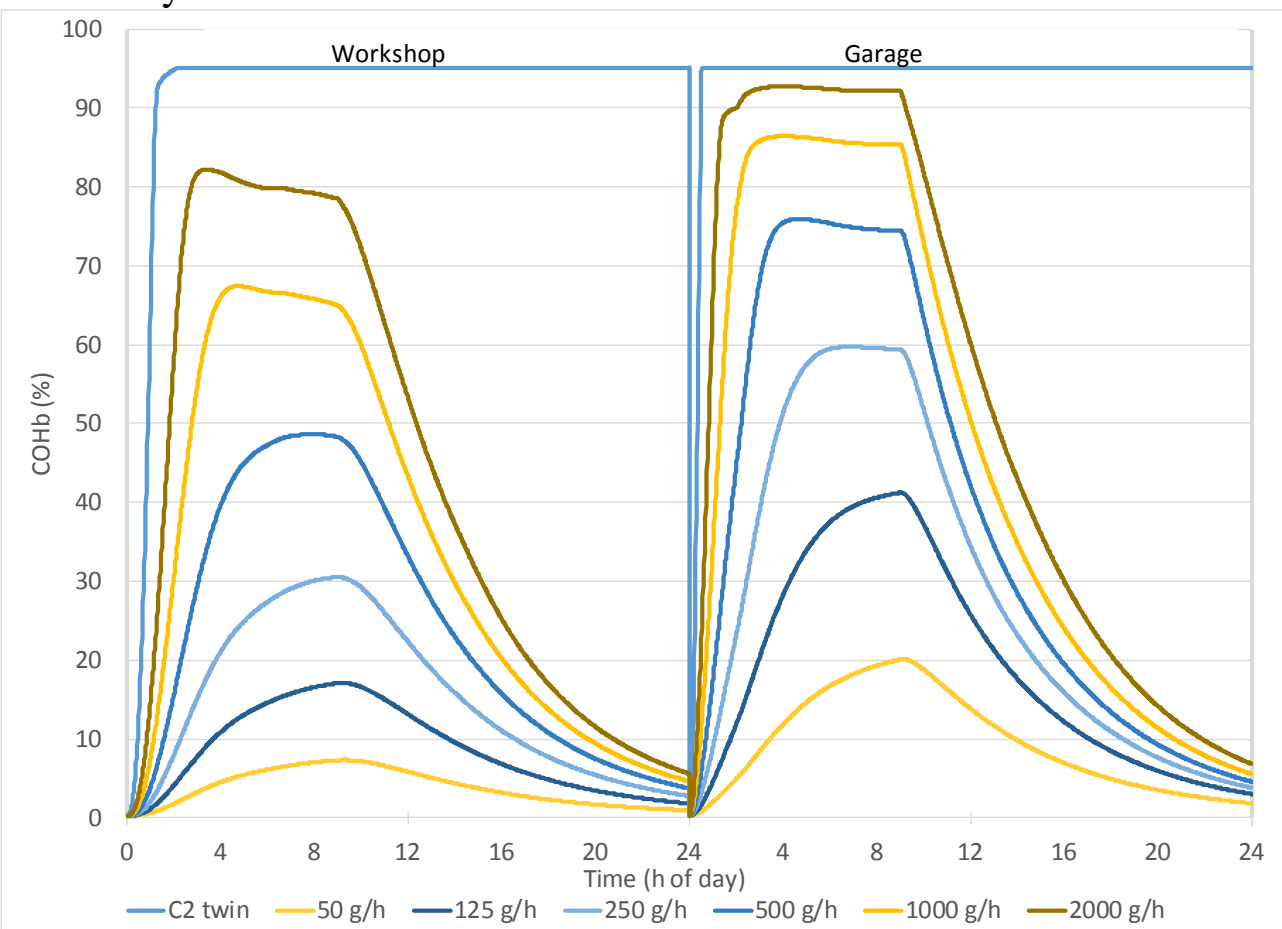

Figure 35 Individual zone transient $\mathrm{COHb}$ (with $\mathrm{RMV}=10 \mathrm{~L} / \mathrm{min}$ ) results for the $\mathrm{C} 2$ twin source in the Garage zone of GAR3 on January $1^{\text {st }}$ 


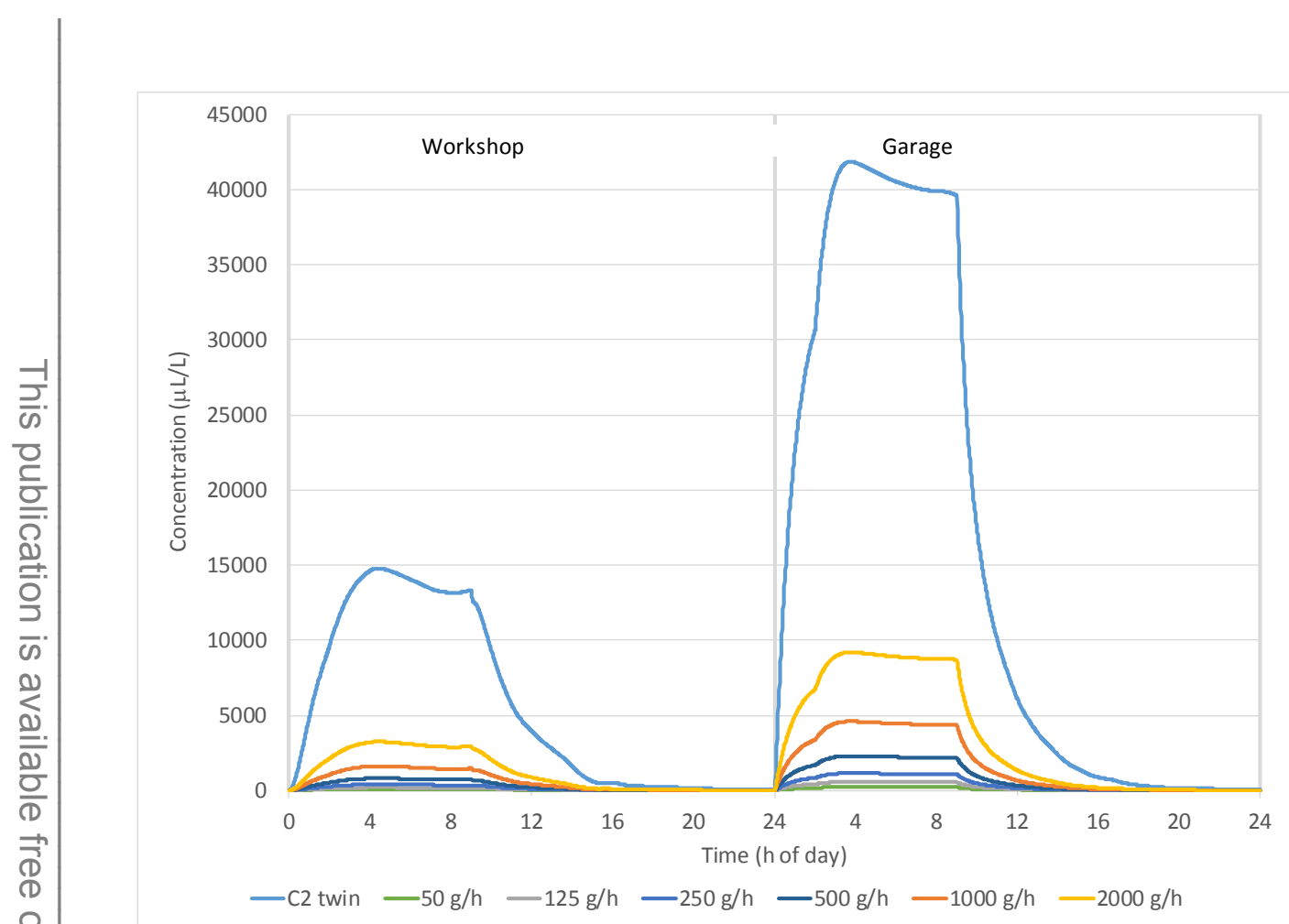

Figure 36 Individual zone transient $\mathrm{CO}$ results for the $\mathrm{C} 2$ twin source in the Garage zone of GAR3 on July $25^{\text {th }}$

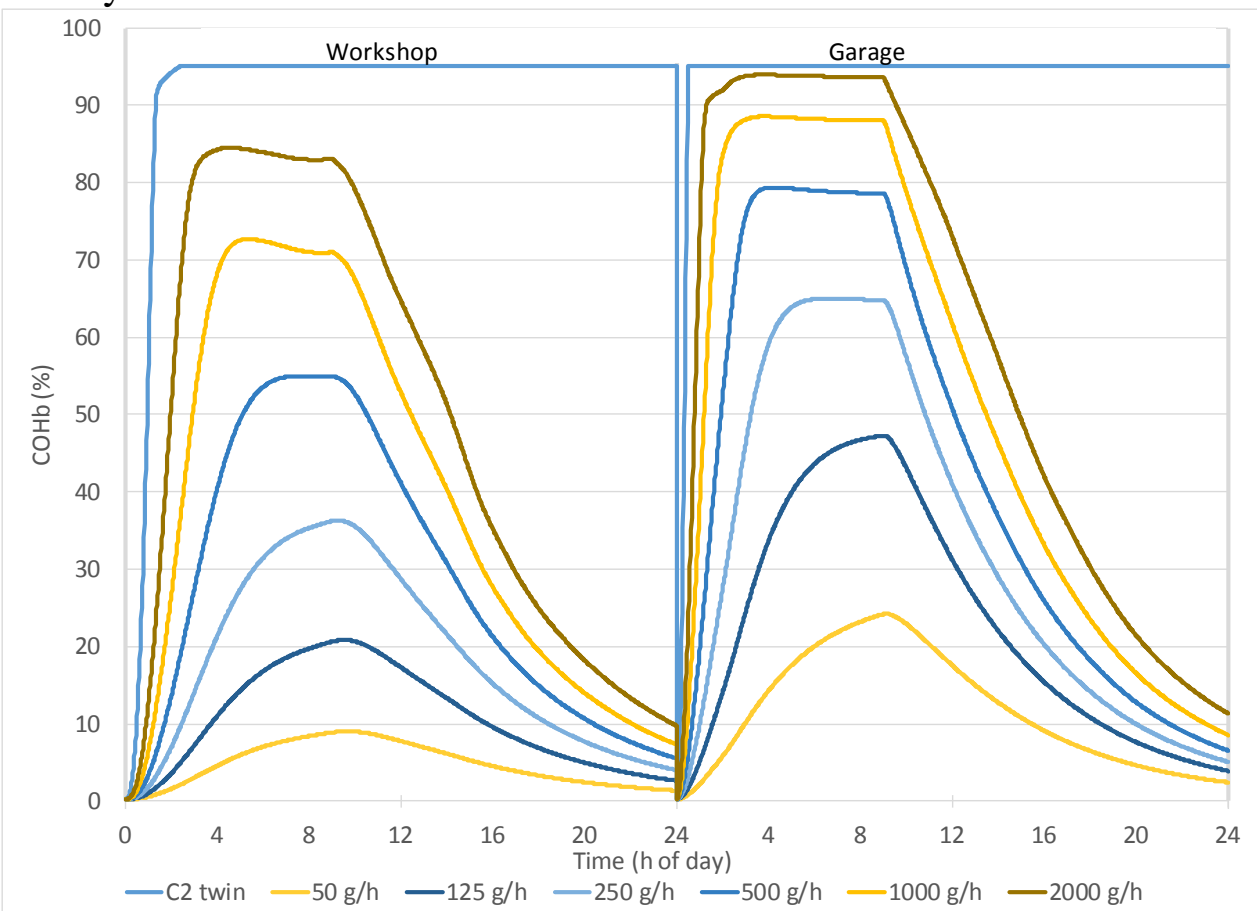

Figure 37 Individual zone transient $\mathrm{COHb}$ (with $\mathrm{RMV}=10 \mathrm{~L} / \mathrm{min}$ ) results for the $\mathrm{C} 2$ twin source in the Garage zone of GAR3 on July $25^{\text {th }}$ 


\section{SUMMARY AND DISCUSSION}

This simulation study was conducted to evaluate indoor $\mathrm{CO}$ exposures as a function of generator source location and CO emission rate in order to support cost-benefit analyses of potential CO emission limits for generators. These simulations employed the multizone airflow and contaminant transport model CONTAM, which was applied to 40 residential buildings including 37 versions of dwellings drawn from a collection that are representative of the U.S. housing stock and 3 new detached garage buildings. A total of over 45 thousand individual 24-hour simulations were conducted that covered a range of house layouts and sizes, airtightness levels, weather conditions, generator locations, CO source strengths and operating schedules. The simulated generator locations include attached garages, crawlspaces and basements, in the houses that have such spaces, and two interior rooms in all of the houses considered. $\mathrm{COHb}$ levels were then calculated from the $\mathrm{CO}$ concentration results for an occupant in each occupiable zone of the buildings over the 24-h simulation period using $3 \mathrm{RMV}$ values. This report presents sample simulation results of predicted $\mathrm{CO}$ concentration and $\mathrm{COHb}$ levels in individual zones for three of the modeled houses and one of the garages.

The results presented demonstrate that the reduced $\mathrm{CO}$ emission rates considered in this study result in peak CO concentrations that are reduced by $40 \%$ to more than $90 \%$ depending on the specific case being analyzed. The reduced $\mathrm{CO}$ emission rates also resulted in significant reductions in $\mathrm{COHb}$ in many cases. Additionally, use of a thermal model to more accurately account for thermal effects was shown to be important as the interaction of the generator heat source and the ambient weather conditions can significantly impact both air change rates and interzone airflow patterns in the buildings.

As observed previously by Persily et al. (2013), these simulation results demonstrate the complexity of multizone airflow and contaminant transport in buildings, which in turn supports the value in considering a wide range of homes and weather conditions in addressing the objective of this study. Variations in house layout, generator size (i.e., source strength and heat release), operating schedules, source location, and weather conditions can all have significant, and at times complex, impacts on airflow and CO transport. This inherent variability means that considering only one or a small number of buildings under a limited range of conditions would not be adequate to fully understand the levels of $\mathrm{CO}$ exposure in residences. Therefore, the results of individual cases, such as the ones presented in this report, should not be over-generalized but taken only as representative of the conditions for those cases. 


\section{ACKNOWLEDGEMENTS}

This work was funded by the U.S. Consumer Products Safety Commission under interagency agreement No. CPSC-I-15-0024. The authors wish to express their appreciation for the support of Janet Buyer, Sandra Inkster, and Matthew Hnatov from CPSC in conducting this effort.

\section{REFERENCES}

ASHRAE, Fundamentals Handbook. 2009. Atlanta, GA: American Society of Heating, Refrigerating and Air-Conditioning Engineers, Inc.

Coburn, R.F., R.E. Forster, and P.B. Kane. 1965. Considerations of the physiological variables that determine the blood carboxyhemoglobin concentration in man. Journal of Clinical Investigation, 1965. 44 (11): p. 1899-1910.

CPSC. 2012. Technology Demonstration of a Prototype Low Carbon Monoxide Emission Portable Generator; U.S. Consumer Product Safety Commission: Bethesda, MD; p 413.

DOE. Residential Energy Consumption Survey (RECS). 2005; Available from: http://www.eia.doe.gov/emeu/recs/contents.html.

Dols, W.S. and B.J. Polidoro. 2015. CONTAM 3.2 User Guide and Program Documentation. NIST Technical Note 1887. National Institute of Standards and Technology.

Emmerich, S.J., Gorfain, J.E., and C. Howard-Reed. 2003. Air and Pollutant Transport from Attached Garages to Residential Living Spaces-Literature Review and Field Test. International Journal of Ventilation, Vol., 2 (3).

Emmerich, S.J. 2001. Validation of Multizone IAQ Modeling of Residential-Scale Buildings: A Review. ASHRAE Transactions. 107 (2): p. 619-628.

Emmerich, S.J. 2006. Simulated Performance of Natural and Hybrid Ventilation Systems in an Office Building. International Journal of HVAC\&R Research Vol. 12 (4).

Emmerich, S.J. and W.S. Dols. 2015. Model Validation Study of Carbon Monoxide Transport due to Portable Generator Operation in an Attached Garage. Journal of Building Performance Simulation Vol. 9 (4): p. 397-410.

Emmerich, S., Persily, A.K., and L. Wang. 2013. Modeling and Measuring the Effects of Portable Gasoline Powered Generator Exhaust on Indoor Carbon Monoxide Level. NIST Technical Note 1781. 
Emmerich, S.J., Howard-Reed, C. and S.J. Nabinger. 2004. Validation of multizone IAQ model predictions for tracer gas in a townhouse. Building Service Engineering Research Technology. 25(4): p. 305-316.

Goldstein, M. 2008. Carbon Monoxide Poisoning. Journal of Emergency Nursing. 34(6): p. 538-542.

Hnatov, M.V. 2015. Incidents, Deaths, and In-Depth Investigations Associated with Non-Fire Carbon Monoxide from Engine-Driven Generators and Other Engine-Driven Tools, 2004-2014. U.S. Consumer Product Safety Commission.

Hnatov, M., S. Inkster, and J. Buyer. 2016 (pending report). Estimates Of Epidemiological Benefits Associated With Reduced Carbon Monoxide (CO) Emission Rates Compared To CO Emission Rates Of Current Portable Generators. U.S. Consumer Product Safety Commission, Bethesda, MD,

HUD. 1999. American Housing Survey for the United States. U.S. Department of Housing and Urban Development, U.S. Department of Commerce.

Persily, A.K., A. Musser, and D. Leber. 2006. A Collection of Homes to Represent the U.S. Housing Stock. NISTIR 7330. National Institute of Standards and Technology.

Persily, A.K., Y. Wang, B. Polidoro, and S. J. Emmerich. 2013. Residential Carbon Monoxide Exposure due to Indoor Generator Operation: Effects of Source Location and Emission Rate. NIST Technical Note 1782.

Peterson, J.E. and R.D. Stewart, Predicting the carboxyhemoglobin levels resulting from carbon monoxide exposures. Journal of Applied Physiology, 1975. 39 (4): p. 633-638.

Poppendieck, D., Khurshid, S., Dols, W.S., Ng, L., Polidoro, B. and S.J. Emmerich. 2016. Formaldehyde Concentrations in a Net-Zero Energy House: Real-time Monitoring and Simulation. Proceedings of Indoor Air 2016

Wang, L., Emmerich, S.J., and A.K. Persily. 2010. In-situ Experimental Study of Carbon Monoxide Generation by Gasoline-Powered Electric Generator in an Enclosed Space. 60: p. 14431451.

Wang, L., Dols, W.S. and S.J. Emmerich. 2012. Simultaneous solutions of coupled thermal airflow problem for natural ventilation in buildings. HVAC\&R Research, 18(1-2), pp.264-274. 


\section{APPENDIX A: House Characteristics}

This appendix contains three tables that define the dwellings in the NIST Suite of Homes, with one table for each housing type: detached (A1), attached (A2) and manufactured home (A3). The dwelling definitions in the table are in terms of the variables discussed in detail in the report that defines these homes (Persily et al. 2006). Note that not all of these models were used in this simulation study and that some of the models were modified to better fit the houses in the CPSC CO incident database. See Appendix B for the details of which houses were used and what modifications were made to the models.

\section{Table A1. Detached Homes (83 total)}

\section{Key for Table A1:}

\# of floors: 1 = one story; 2 = two story

Floor area: 1 = less than $148.5 \mathrm{~m}^{2}\left(1,599 \mathrm{ft}^{2}\right) ; 2=148.6 \mathrm{~m}^{2}$ to $222.9 \mathrm{~m}^{2}\left(1,600 \mathrm{ft}^{2}\right.$ to $\left.2,399 \mathrm{ft}^{2}\right) ; 3=223.0 \mathrm{~m}^{2}\left(2,400 \mathrm{ft}^{2}\right)$ or more Year Built: 1 = before 1940; 2 = 1940-69; $3=1970-89 ; 4=1990$ and newer

Foundation: 1 = concrete slab; 2 = crawl space; 3 = finished basement, 4 = unfinished basement

Garage: 1 = none; 2 = attached garage

Forced Air: 1 = other; 2 = central system present

\begin{tabular}{|c|c|c|c|c|c|c|c|c|c|c|c|}
\hline \multirow[b]{2}{*}{$\begin{array}{c}\text { House } \\
\text { Number }\end{array}$} & \multirow[b]{2}{*}{ \# of Floors } & \multicolumn{5}{|c|}{ House Variable } & \multicolumn{4}{|c|}{ \# of Rooms } & \multirow[b]{2}{*}{$\begin{array}{c}\text { Floor } \\
\text { plan }\end{array}$} \\
\hline & & Floor area & Year Built & Foundation & Garage & $\begin{array}{c}\text { Forced } \\
\text {-air }\end{array}$ & Bedrooms & $\begin{array}{c}\text { Full } \\
\text { baths }\end{array}$ & Half baths & Other & \\
\hline DH-1 & 1 & 2 & 3 & 1 & 2 & 2 & 3 & 2 & 0 & 3 & DH-B(1) \\
\hline DH-2 & 1 & 1 & 2 & 3 & 2 & 2 & 3 & 1 & 0 & 3 & $\mathrm{DH}-\mathrm{A}(8)$ \\
\hline DH-3 & 1 & 1 & 2 & 2 & 1 & 1 & 2 & 1 & 0 & 2 & DH-A(1) \\
\hline $\mathrm{DH}-4$ & 1 & 1 & 2 & 2 & 2 & 2 & 3 & 1 & 0 & 3 & $\mathrm{DH}-\mathrm{A}(7)$ \\
\hline DH-5 & 1 & 1 & 3 & 1 & 2 & 2 & 3 & 2 & 0 & 3 & $\mathrm{DH}-\mathrm{A}(2)$ \\
\hline DH-6 & 2 & 1 & 1 & 3 & 2 & 2 & 3 & 1 & 0 & 3 & DH-D(3) \\
\hline DH-7 & 1 & 2 & 2 & 3 & 2 & 2 & 3 & 2 & 0 & 4 & $\mathrm{DH}-\mathrm{B}(5)$ \\
\hline DH-8 & 1 & 1 & 2 & 1 & 2 & 2 & 3 & 2 & 0 & 3 & $\mathrm{DH}-\mathrm{A}(2)$ \\
\hline DH-9 & 2 & 1 & 2 & 3 & 2 & 2 & 3 & 1 & 0 & 3 & DH-D(3) \\
\hline DH-10 & 2 & 2 & 3 & 3 & 2 & 2 & 4 & 2 & 1 & 4 & DH-E(8) \\
\hline
\end{tabular}




\begin{tabular}{|c|c|c|c|c|c|c|c|c|c|c|c|}
\hline \multirow[b]{2}{*}{$\begin{array}{c}\text { House } \\
\text { Number }\end{array}$} & \multirow[b]{2}{*}{ \# of Floors } & \multicolumn{5}{|c|}{ House Variable } & \multicolumn{4}{|c|}{ \# of Rooms } & \multirow[b]{2}{*}{$\begin{array}{l}\text { Floor } \\
\text { plan }\end{array}$} \\
\hline & & Floor area & Year Built & Foundation & Garage & $\begin{array}{c}\text { Forced } \\
\text {-air }\end{array}$ & Bedrooms & $\begin{array}{c}\text { Full } \\
\text { baths }\end{array}$ & Half baths & Other & \\
\hline DH-11 & 1 & 1 & 2 & 2 & 2 & 1 & 3 & 1 & 0 & 3 & DH-A(7) \\
\hline DH-12 & 2 & 3 & 3 & 3 & 2 & 2 & 4 & 2 & 1 & 5 & DH-F(4) \\
\hline DH-13 & 1 & 2 & 2 & 2 & 2 & 2 & 3 & 2 & 0 & 3 & $\mathrm{DH}-\mathrm{B}(1)$ \\
\hline DH-14 & 2 & 2 & 1 & 3 & 2 & 2 & 3 & 1 & 1 & 4 & DH-E(5) \\
\hline DH-15 & 2 & 3 & 4 & 3 & 2 & 2 & 4 & 3 & 1 & 5 & DH-F(5) \\
\hline DH-16 & 1 & 1 & 2 & 2 & 1 & 2 & 3 & 1 & 0 & 3 & DH-A(7) \\
\hline DH-17 & 2 & 2 & 2 & 3 & 2 & 2 & 3 & 2 & 1 & 4 & DH-E(6) \\
\hline DH-18 & 2 & 1 & 1 & 3 & 1 & 2 & 3 & 1 & 0 & 3 & DH-D(3) \\
\hline DH-19 & 1 & 1 & 3 & 3 & 2 & 2 & 3 & 1 & 0 & 3 & DH-A(8) \\
\hline DH-20 & 2 & 2 & 1 & 3 & 2 & 1 & 4 & 1 & 0 & 4 & DH-E(7) \\
\hline DH-21 & 1 & 1 & 2 & 1 & 1 & 2 & 3 & 1 & 0 & 3 & DH-A(7) \\
\hline DH-22 & 2 & 3 & 3 & 1 & 2 & 2 & 4 & 3 & 1 & 5 & DH-F(1) \\
\hline DH-23 & 2 & 1 & 1 & 3 & 2 & 1 & 3 & 1 & 0 & 3 & DH-D(3) \\
\hline DH-24 & 2 & 2 & 3 & 1 & 2 & 2 & 4 & 2 & 1 & 4 & DH-E(3) \\
\hline DH-25 & 1 & 1 & 2 & 3 & 2 & 1 & 3 & 1 & 0 & 3 & DH-A(8) \\
\hline DH-26 & 1 & 1 & 2 & 1 & 1 & 1 & 2 & 1 & 0 & 2 & DH-A(1) \\
\hline DH-27 & 1 & 1 & 2 & 3 & 1 & 2 & 3 & 1 & 0 & 3 & DH-A(8) \\
\hline DH-28 & 2 & 3 & 4 & 1 & 2 & 2 & 4 & 3 & 1 & 4 & $\mathrm{DH}-\mathrm{F}(2)$ \\
\hline DH-29 & 1 & 1 & 1 & 2 & 1 & 1 & 2 & 1 & 0 & 3 & DH-A(3) \\
\hline DH-30 & 1 & 2 & 3 & 2 & 2 & 2 & 3 & 2 & 0 & 3 & DH-B(1) \\
\hline DH-31 & 1 & 1 & 3 & 2 & 2 & 2 & 3 & 2 & 0 & 3 & DH-A(2) \\
\hline DH-32 & 1 & 1 & 4 & 1 & 2 & 2 & 3 & 2 & 0 & 2 & DH-A(6) \\
\hline DH-33 & 1 & 3 & 3 & 1 & 2 & 2 & 4 & 2 & 0 & 4 & DH-C(1) \\
\hline DH-34 & 1 & 1 & 3 & 1 & 1 & 2 & 3 & 1 & 0 & 3 & DH-A(7) \\
\hline DH-35 & 1 & 2 & 2 & 1 & 2 & 2 & 3 & 2 & 0 & 3 & $\mathrm{DH}-\mathrm{B}(1)$ \\
\hline DH-36 & 2 & 2 & 4 & 1 & 2 & 2 & 4 & 2 & 1 & 4 & DH-E(3) \\
\hline DH-37 & 1 & 2 & 3 & 3 & 2 & 2 & 3 & 2 & 1 & 3 & DH-B(4) \\
\hline DH-38 & 1 & 1 & 3 & 2 & 1 & 2 & 3 & 1 & 0 & 3 & DH-A(7) \\
\hline
\end{tabular}




\begin{tabular}{|c|c|c|c|c|c|c|c|c|c|c|c|}
\hline \multirow[b]{2}{*}{$\begin{array}{c}\text { House } \\
\text { Number } \\
\end{array}$} & \multirow[b]{2}{*}{ \# of Floors } & \multicolumn{5}{|c|}{ House Variable } & \multicolumn{4}{|c|}{ \# of Rooms } & \multirow[b]{2}{*}{$\begin{array}{l}\text { Floor } \\
\text { plan }\end{array}$} \\
\hline & & Floor area & Year Built & Foundation & Garage & $\begin{array}{c}\text { Forced } \\
\text {-air }\end{array}$ & Bedrooms & $\begin{array}{c}\text { Full } \\
\text { baths }\end{array}$ & Half baths & Other & \\
\hline DH-39 & 1 & 2 & 2 & 2 & 1 & 2 & 3 & 2 & 0 & 3 & $\mathrm{DH}-\mathrm{B}(1)$ \\
\hline DH-40 & 2 & 2 & 3 & 2 & 2 & 2 & 4 & 2 & 1 & 4 & DH-E(3) \\
\hline DH-41 & 2 & 2 & 1 & 3 & 1 & 2 & 3 & 1 & 0 & 4 & DH-E(1) \\
\hline DH-42 & 1 & 1 & 3 & 2 & 1 & 1 & 3 & 1 & 0 & 2 & DH-A(4) \\
\hline DH-43 & 2 & 2 & 2 & 3 & 2 & 1 & 4 & 2 & 0 & 4 & DH-E(2) \\
\hline DH-44 & 1 & 1 & 1 & 3 & 2 & 2 & 2 & 1 & 0 & 3 & DH-A(9) \\
\hline DH-45 & 2 & 2 & 3 & 4 & 2 & 1 & 4 & 2 & 1 & 4 & DH-E(3) \\
\hline DH-46 & 1 & 1 & 2 & 1 & 2 & 1 & 2 & 1 & 0 & 2 & $\mathrm{DH}-\mathrm{A}(1)$ \\
\hline DH-47 & 1 & 1 & 3 & 2 & 2 & 1 & 3 & 1 & 0 & 3 & DH-A(7) \\
\hline DH-48 & 1 & 1 & 4 & 2 & 1 & 2 & 3 & 2 & 0 & 3 & $\mathrm{DH}-\mathrm{A}(2)$ \\
\hline DH-49 & 1 & 1 & 2 & 3 & 1 & 1 & 3 & 1 & 0 & 3 & $\mathrm{DH}-\mathrm{A}(8)$ \\
\hline DH-50 & 2 & 1 & 1 & 3 & 1 & 1 & 3 & 1 & 0 & 3 & DH-D(3) \\
\hline DH-51 & 2 & 3 & 3 & 2 & 2 & 2 & 4 & 2 & 1 & 4 & DH-F(3) \\
\hline DH-52 & 2 & 3 & 1 & 4 & 2 & 2 & 4 & 2 & 1 & 4 & DH-F(3) \\
\hline DH-53 & 1 & 2 & 3 & 1 & 1 & 2 & 3 & 2 & 0 & 3 & $\mathrm{DH}-\mathrm{B}(1)$ \\
\hline DH-54 & 1 & 1 & 1 & 2 & 1 & 2 & 2 & 1 & 0 & 3 & DH-A(3) \\
\hline DH-55 & 1 & 1 & 4 & 2 & 2 & 2 & 3 & 2 & 0 & 2 & DH-A(6) \\
\hline DH-56 & 2 & 1 & 2 & 3 & 1 & 2 & 3 & 1 & 0 & 3 & $\mathrm{DH}-\mathrm{D}(3)$ \\
\hline DH-57 & 1 & 2 & 2 & 2 & 2 & 1 & 3 & 2 & 0 & 4 & DH-B(3) \\
\hline DH-58 & 2 & 2 & 4 & 3 & 2 & 2 & 3 & 2 & 1 & 4 & DH-E(6) \\
\hline DH-59 & 2 & 3 & 2 & 3 & 2 & 1 & 4 & 2 & 1 & 5 & DH-F(4) \\
\hline DH-60 & 1 & 1 & 3 & 4 & 2 & 1 & 3 & 1 & 0 & 3 & $\mathrm{DH}-\mathrm{A}(7)$ \\
\hline DH-61 & 1 & 1 & 1 & 4 & 1 & 2 & 2 & 1 & 0 & 2 & DH-A(1) \\
\hline DH-62 & 2 & 3 & 1 & 3 & 2 & 1 & 4 & 2 & 1 & 5 & $\mathrm{DH}-\mathrm{F}(4)$ \\
\hline DH-63 & 2 & 1 & 2 & 4 & 2 & 1 & 3 & 1 & 1 & 3 & DH-D(4) \\
\hline DH-64 & 1 & 2 & 4 & 1 & 2 & 2 & 3 & 2 & 0 & 3 & $\mathrm{DH}-\mathrm{B}(1)$ \\
\hline DH-65 & 1 & 1 & 1 & 4 & 1 & 1 & 2 & 1 & 0 & 3 & DH-A(3) \\
\hline DH-66 & 1 & 2 & 2 & 1 & 2 & 1 & 3 & 1 & 0 & 3 & $\mathrm{DH}-\mathrm{B}(2)$ \\
\hline
\end{tabular}




\begin{tabular}{|c|c|c|c|c|c|c|c|c|c|c|c|}
\hline \multirow[b]{2}{*}{$\begin{array}{c}\text { House } \\
\text { Number } \\
\end{array}$} & \multirow[b]{2}{*}{ \# of Floors } & \multicolumn{5}{|c|}{ House Variable } & \multicolumn{4}{|c|}{ \# of Rooms } & \multirow[b]{2}{*}{$\begin{array}{l}\text { Floor } \\
\text { plan }\end{array}$} \\
\hline & & Floor area & Year Built & Foundation & Garage & $\begin{array}{c}\text { Forced } \\
\text {-air }\end{array}$ & Bedrooms & $\begin{array}{c}\text { Full } \\
\text { baths }\end{array}$ & Half baths & Other & \\
\hline DH-67 & 1 & 1 & 1 & 2 & 2 & 2 & 3 & 1 & 0 & 3 & DH-A(7) \\
\hline DH-68 & 2 & 1 & 2 & 3 & 1 & 1 & 3 & 1 & 0 & 3 & DH-D(3) \\
\hline DH-69 & 2 & 3 & 3 & 4 & 2 & 1 & 4 & 2 & 1 & 4 & DH-F(3) \\
\hline DH-70 & 1 & 1 & 3 & 1 & 1 & 1 & 2 & 1 & 0 & 2 & DH-A(1) \\
\hline DH-71 & 2 & 1 & 3 & 1 & 2 & 2 & 3 & 2 & 1 & 3 & DH-D(1) \\
\hline DH-72 & 1 & 2 & 1 & 4 & 2 & 2 & 3 & 2 & 0 & 4 & DH-B(3) \\
\hline DH-73 & 2 & 1 & 3 & 4 & 2 & 2 & 3 & 2 & 0 & 4 & DH-D(2) \\
\hline DH-74 & 1 & 3 & 3 & 4 & 2 & 2 & 3 & 2 & 1 & 5 & $\mathrm{DH}-\mathrm{C}(2)$ \\
\hline DH-75 & 3 & 2 & 3 & 1 & 2 & 2 & 4 & 2 & 1 & 3 & $\mathrm{DH}-\mathrm{G}(1)$ \\
\hline DH-76 & 1 & 1 & 4 & 4 & 2 & 2 & 3 & 2 & 1 & 3 & DH-A(5) \\
\hline DH-77 & 3 & 2 & 3 & 4 & 2 & 2 & 3 & 2 & 1 & 4 & $\mathrm{DH}-\mathrm{G}(2)$ \\
\hline DH-78 & 1 & 1 & 3 & 1 & 2 & 1 & 3 & 1 & 0 & 3 & DH-A(7) \\
\hline DH-79 & 1 & 2 & 3 & 2 & 1 & 2 & 3 & 2 & 0 & 3 & DH-B(1) \\
\hline DH-80 & 1 & 2 & 2 & 4 & 1 & 2 & 3 & 2 & 0 & 4 & $\mathrm{DH}-\mathrm{B}(3)$ \\
\hline DH-81 & 2 & 2 & 1 & 4 & 1 & 1 & 3 & 2 & 0 & 4 & DH-E(4) \\
\hline DH-82 & 1 & 2 & 2 & 4 & 2 & 1 & 3 & 2 & 0 & 3 & DH-B(1) \\
\hline DH-83 & 1 & 1 & 3 & 3 & 1 & 2 & 3 & 1 & 0 & 3 & DH-A(8) \\
\hline
\end{tabular}




\section{Key for Table A2:}

\# of floors: 1 = one story; 2 = two story

Floor area: 1 = fewer than $148.5 \mathrm{~m}^{2}\left(1,599 \mathrm{ft}^{2}\right) ; 2=148.6 \mathrm{~m}^{2}$ to $222.9 \mathrm{~m}^{2}\left(1,600 \mathrm{ft}^{2}\right.$ to 2,399 $\left.\mathrm{ft}^{2}\right) ; 3=223.0 \mathrm{~m}^{2}\left(2,400 \mathrm{ft}^{2}\right)$ or more Year Built: 1 = before 1940; 2 = 1940-69; $3=1970-89 ; 4=1990$ and newer

Foundation: 1 = concrete slab; 2 = crawl space; 3 = finished basement, 4 = unfinished basement

Garage: 1 = none; 2 = attached garage

Forced Air: 1 = other; 2 = central system present

\begin{tabular}{|c|c|c|c|c|c|c|c|c|c|c|c|}
\hline \multirow[b]{2}{*}{$\begin{array}{c}\text { House } \\
\text { Number }\end{array}$} & \multirow[b]{2}{*}{$\begin{array}{c}\text { \# of } \\
\text { Floors }\end{array}$} & \multicolumn{5}{|c|}{ House Variable } & \multicolumn{4}{|c|}{ \# of Rooms } & \multirow[b]{2}{*}{ Floor plan } \\
\hline & & $\begin{array}{c}\text { Floor } \\
\text { area }\end{array}$ & $\begin{array}{l}\text { Year } \\
\text { Built }\end{array}$ & $\begin{array}{c}\text { Found } \\
\text {-ation }\end{array}$ & Garage & $\begin{array}{c}\text { Forced } \\
\text {-air }\end{array}$ & $\begin{array}{c}\text { Bed- } \\
\text { rooms }\end{array}$ & $\begin{array}{c}\text { Full } \\
\text { baths }\end{array}$ & $\begin{array}{c}\text { Half } \\
\text { baths }\end{array}$ & Other & \\
\hline $\mathrm{AH}-1$ & 2 & 1 & 1 & 3 & 1 & 2 & 2 & 1 & 0 & 3 & $\mathrm{AH}-\mathrm{C}(11)$ \\
\hline AH-2 & 2 & 1 & 3 & 1 & 1 & 2 & 2 & 2 & 1 & 3 & $\mathrm{AH}-\mathrm{C}(7)$ \\
\hline AH-3 & 1 & 1 & 3 & 1 & 1 & 2 & 2 & 1 & 0 & 2 & $\mathrm{AH}-\mathrm{A}(2)$ \\
\hline $\mathrm{AH}-4$ & 1 & 1 & 3 & 1 & 2 & 2 & 2 & 1 & 0 & 3 & $\mathrm{AH}-\mathrm{A}(3)$ \\
\hline AH-5 & 2 & 1 & 2 & 3 & 1 & 1 & 3 & 1 & 0 & 3 & AH-C(15) \\
\hline AH-6 & 2 & 1 & 3 & 1 & 2 & 2 & 2 & 2 & 1 & 3 & $\mathrm{AH}-\mathrm{C}(4)$ \\
\hline $\mathrm{AH}-7$ & 2 & 1 & 3 & 3 & 1 & 2 & 3 & 2 & 1 & 3 & $\mathrm{AH}-\mathrm{C}(16)$ \\
\hline AH-8 & 1 & 1 & 2 & 1 & 1 & 1 & 2 & 1 & 0 & 2 & $\mathrm{AH}-\mathrm{A}(2)$ \\
\hline AH-9 & 2 & 1 & 1 & 3 & 2 & 1 & 3 & 2 & 1 & 4 & $\mathrm{AH}-\mathrm{C}(17)$ \\
\hline AH-10 & 2 & 1 & 1 & 3 & 1 & 1 & 2 & 1 & 0 & 3 & AH-C(11) \\
\hline AH-11 & 2 & 1 & 2 & 3 & 1 & 2 & 3 & 1 & 0 & 3 & AH-C(15) \\
\hline AH-12 & 1 & 1 & 4 & 1 & 2 & 2 & 2 & 1 & 0 & 2 & $\mathrm{AH}-\mathrm{A}(1)$ \\
\hline AH-13 & 2 & 1 & 2 & 1 & 1 & 2 & 2 & 2 & 1 & 2 & $\mathrm{AH}-\mathrm{C}(6)$ \\
\hline AH-14 & 1 & 1 & 2 & 1 & 1 & 2 & 2 & 1 & 0 & 2 & $\mathrm{AH}-\mathrm{A}(2)$ \\
\hline AH-15 & 2 & 2 & 3 & 1 & 2 & 2 & 3 & 1 & 0 & 3 & $\mathrm{AH}-\mathrm{D}(1)$ \\
\hline AH-16 & 2 & 1 & 1 & 2 & 1 & 1 & 2 & 1 & 0 & 2 & $\mathrm{AH}-\mathrm{C}(2)$ \\
\hline AH-17 & 1 & 1 & 2 & 2 & 1 & 1 & 1 & 1 & 0 & 2 & $\mathrm{AH}-\mathrm{A}(5)$ \\
\hline AH-18 & 2 & 1 & 3 & 1 & 1 & 1 & 2 & 1 & 0 & 2 & $\mathrm{AH}-\mathrm{C}(2)$ \\
\hline AH-19 & 2 & 1 & 2 & 1 & 2 & 2 & 2 & 1 & 0 & 3 & $\mathrm{AH}-\mathrm{C}(3)$ \\
\hline
\end{tabular}




\begin{tabular}{|c|c|c|c|c|c|c|c|c|c|c|c|}
\hline \multirow[b]{2}{*}{$\begin{array}{c}\text { House } \\
\text { Number }\end{array}$} & \multirow[b]{2}{*}{$\begin{array}{c}\text { \# of } \\
\text { Floors }\end{array}$} & \multicolumn{5}{|c|}{ House Variable } & \multicolumn{4}{|c|}{ \# of Rooms } & \multirow[b]{2}{*}{ Floor plan } \\
\hline & & $\begin{array}{c}\text { Floor } \\
\text { area }\end{array}$ & $\begin{array}{l}\text { Year } \\
\text { Built }\end{array}$ & $\begin{array}{l}\text { Found } \\
\text {-ation }\end{array}$ & Garage & $\begin{array}{l}\text { Forced } \\
\text {-air }\end{array}$ & $\begin{array}{c}\text { Bed- } \\
\text { rooms }\end{array}$ & $\begin{array}{c}\text { Full } \\
\text { baths }\end{array}$ & $\begin{array}{c}\text { Half } \\
\text { baths }\end{array}$ & Other & \\
\hline AH-20 & 2 & 1 & 1 & 4 & 2 & 2 & 3 & 1 & 0 & 3 & AH-C(12) \\
\hline AH-21 & 2 & 2 & 1 & 4 & 2 & 2 & 3 & 1 & 0 & 3 & AH-D(4) \\
\hline AH-22 & 2 & 1 & 3 & 1 & 2 & 1 & 2 & 2 & 1 & 2 & $\mathrm{AH}-\mathrm{C}(1)$ \\
\hline AH-23 & 2 & 1 & 3 & 4 & 2 & 2 & 3 & 2 & 1 & 3 & AH-C(13) \\
\hline AH-24 & 2 & 2 & 1 & 3 & 1 & 1 & 3 & 1 & 0 & 3 & AH-D(5) \\
\hline AH-25 & 1 & 1 & 2 & 1 & 2 & 1 & 2 & 1 & 0 & 2 & AH-A(1) \\
\hline AH-26 & 2 & 1 & 4 & 1 & 1 & 2 & 3 & 2 & 1 & 2 & $\mathrm{AH}-\mathrm{C}(5)$ \\
\hline AH-27 & 2 & 2 & 1 & 4 & 2 & 1 & 3 & 1 & 0 & 5 & AH-D(6) \\
\hline AH-28 & 2 & 2 & 3 & 3 & 1 & 2 & 3 & 2 & 1 & 3 & AH-D(7) \\
\hline AH-29 & 2 & 2 & 4 & 1 & 2 & 2 & 2 & 1 & 0 & 3 & AH-D(2) \\
\hline AH-30 & 1 & 1 & 3 & 2 & 2 & 1 & 2 & 1 & 0 & 2 & AH-A(1) \\
\hline AH-31 & 1 & 1 & 2 & 3 & 1 & 2 & 1 & 1 & 0 & 3 & $\mathrm{AH}-\mathrm{A}(7)$ \\
\hline AH-32 & 1 & 1 & 2 & 4 & 2 & 2 & 2 & 1 & 0 & 3 & $\mathrm{AH}-\mathrm{A}(4)$ \\
\hline AH-33 & 1 & 1 & 1 & 3 & 1 & 2 & 1 & 1 & 0 & 2 & $\mathrm{AH}-\mathrm{A}(6)$ \\
\hline AH-34 & 2 & 3 & 3 & 3 & 1 & 2 & 4 & 3 & 2 & 4 & AH-E(1) \\
\hline AH-35 & 2 & 1 & 2 & 1 & 1 & 1 & 2 & 1 & 0 & 2 & $\mathrm{AH}-\mathrm{C}(2)$ \\
\hline AH-36 & 1 & 1 & 2 & 1 & 2 & 2 & 2 & 1 & 0 & 2 & AH-A(1) \\
\hline AH-37 & 1 & 1 & 2 & 2 & 2 & 1 & 2 & 1 & 0 & 2 & $\mathrm{AH}-\mathrm{A}(1)$ \\
\hline AH-38 & 1 & 1 & 1 & 4 & 2 & 1 & 2 & 1 & 0 & 3 & $\mathrm{AH}-\mathrm{A}(4)$ \\
\hline AH-39 & 1 & 1 & 4 & 1 & 1 & 2 & 2 & 1 & 0 & 2 & $\mathrm{AH}-\mathrm{A}(2)$ \\
\hline $\mathrm{AH}-40$ & 2 & 1 & 1 & 1 & 1 & 1 & 1 & 1 & 0 & 1 & AH-C(8) \\
\hline AH-41 & 2 & 2 & 2 & 3 & 1 & 2 & 3 & 2 & 1 & 4 & AH-D(8) \\
\hline AH-42 & 2 & 1 & 2 & 4 & 2 & 2 & 2 & 1 & 0 & 3 & AH-C(10) \\
\hline $\mathrm{AH}-43$ & 1 & 2 & 3 & 1 & 2 & 2 & 3 & 1 & 0 & 3 & $\mathrm{AH}-\mathrm{B}(1)$ \\
\hline $\mathrm{AH}-44$ & 1 & 1 & 3 & 2 & 1 & 1 & 1 & 1 & 0 & 2 & $\mathrm{AH}-\mathrm{A}(5)$ \\
\hline AH-45 & 1 & 1 & 2 & 2 & 1 & 2 & 2 & 1 & 0 & 2 & $\mathrm{AH}-\mathrm{A}(2)$ \\
\hline $\mathrm{AH}-46$ & 2 & 1 & 2 & 2 & 1 & 2 & 3 & 1 & 0 & 3 & $\mathrm{AH}-\mathrm{C}(9)$ \\
\hline $\mathrm{AH}-47$ & 1 & 1 & 3 & 4 & 2 & 2 & 3 & 2 & 1 & 3 & AH-A(8) \\
\hline
\end{tabular}




\begin{tabular}{|c|c|c|c|c|c|c|c|c|c|c|c|}
\hline & & \multicolumn{9}{|c|}{ House Variable } & \multicolumn{4}{c|}{ \# of Rooms } & \\
\cline { 3 - 13 } $\begin{array}{c}\text { House } \\
\text { Number }\end{array}$ & $\begin{array}{c}\text { \# of } \\
\text { Floors }\end{array}$ & $\begin{array}{c}\text { Floor } \\
\text { area }\end{array}$ & $\begin{array}{c}\text { Year } \\
\text { Built }\end{array}$ & $\begin{array}{c}\text { Found } \\
\text {-ation }\end{array}$ & Garage & $\begin{array}{c}\text { Forced } \\
\text {-air }\end{array}$ & $\begin{array}{c}\text { Bed- } \\
\text { rooms }\end{array}$ & $\begin{array}{c}\text { Full } \\
\text { baths }\end{array}$ & $\begin{array}{c}\text { Half } \\
\text { baths }\end{array}$ & Other & Floor plan \\
\hline AH-48 & 2 & 1 & 3 & 2 & 1 & 2 & 2 & 2 & 1 & 2 & $\mathrm{AH}-\mathrm{C}(6)$ \\
\hline $\mathrm{AH}-49$ & 1 & 1 & 1 & 2 & 2 & 1 & 2 & 1 & 0 & 2 & $\mathrm{AH}-\mathrm{A}(1)$ \\
\hline $\mathrm{AH}-50$ & 2 & 1 & 3 & 2 & 2 & 2 & 2 & 2 & 1 & 3 & $\mathrm{AH}-\mathrm{C}(4)$ \\
\hline $\mathrm{AH}-51$ & 2 & 1 & 3 & 3 & 1 & 1 & 2 & 1 & 0 & 3 & $\mathrm{AH}-\mathrm{C}(11)$ \\
\hline $\mathrm{AH}-52$ & 2 & 2 & 3 & 1 & 1 & 2 & 3 & 2 & 1 & 4 & $\mathrm{AH}-\mathrm{D}(3)$ \\
\hline $\mathrm{AH}-53$ & 1 & 1 & 4 & 2 & 1 & 2 & 2 & 1 & 0 & 2 & $\mathrm{AH}-\mathrm{A}(2)$ \\
\hline
\end{tabular}

TABLE A3. Manufactured Homes

Key for Table A3:

Floor area: 1 = less than $148.5 \mathrm{~m}^{2}\left(1,599 \mathrm{ft}^{2}\right) ; 2=148.6 \mathrm{~m}^{2}\left(1,600 \mathrm{ft}^{2}\right)$ or more

Year Built: 1 = before 1940; 2 = 1940-69; 3 = 1970-89; 4 = 1990 and newer

Forced Air: 1 = other; 2 = central system present

\begin{tabular}{|c|c|c|c|c|c|c|c|c|}
\hline $\begin{array}{c}\text { House } \\
\text { Number }\end{array}$ & $\begin{array}{c}\text { Floor } \\
\text { area }\end{array}$ & $\begin{array}{c}\text { Year } \\
\text { Built }\end{array}$ & $\begin{array}{c}\text { Forced- } \\
\text { air }\end{array}$ & $\begin{array}{c}\text { \# of } \\
\text { Bedrooms }\end{array}$ & $\begin{array}{c}\text { \# of } \\
\text { Baths }\end{array}$ & $\begin{array}{c}\text { \# of Half } \\
\text { baths }\end{array}$ & $\begin{array}{c}\text { \# of Other } \\
\text { rooms }\end{array}$ & Floor plan \\
\hline MH-1 & 1 & 3 & 2 & 2 & 1 & 0 & 2 & $\mathrm{MH}-\mathrm{B}(1)$ \\
\hline $\mathrm{MH}-2$ & 1 & 4 & 2 & 3 & 2 & 0 & 2 & $\mathrm{MH}-\mathrm{A}(1)$ \\
\hline $\mathrm{MH}-3$ & 1 & 3 & 1 & 2 & 1 & 0 & 2 & $\mathrm{MH}-\mathrm{B}(1)$ \\
\hline $\mathrm{MH}-4$ & 1 & 2 & 2 & 2 & 1 & 0 & 2 & $\mathrm{MH}-\mathrm{B}(1)$ \\
\hline
\end{tabular}




\section{Appendix B Source Locations and Model Modifications for Each Building}

Table B1 lists the 40 buildings modeled in this simulation study and shows the locations of the generator simulated for each building. Based on CPSC analysis of CO poisoning death incidents from 2004 through 2012, a subset of the NIST suite of homes collection described above (in some cases with modifications to better represent the houses in the CPSC CO incident database) were used for this analysis including 31 detached house (DH) models, 4 attached house (AH) models, and 2 manufactured house (MH) models. Any modifications are listed in Table B1 and described in more detail below.

Three new building models were created to represent various forms of garages (GAR) modeled including 2 single-zone garage/sheds (1 car size and 2 car size) and 1 larger garage with a separate work space inside as described below.

Table B1. Source Locations and Model Modifications for Each Building

\begin{tabular}{|c|c|c|c|c|c|}
\hline \multirow[b]{2}{*}{$\begin{array}{l}\text { House } \\
\text { number }\end{array}$} & & & \multicolumn{3}{|c|}{ Source locations } \\
\hline & $\begin{array}{l}\text { PRJ file } \\
\text { modified } \\
\text { (yes/no)? }\end{array}$ & $\begin{array}{l}\text { Floor } \\
\text { plan }\end{array}$ & Garage & $\begin{array}{l}\text { Basement/ } \\
\text { crawlspace }\end{array}$ & Interior room(s) \\
\hline DH-1 & $\mathrm{N}$ & $\mathrm{DH}-\mathrm{B}(1)$ & GAR & n.a. & Kit, Bed3 \\
\hline DH-2 & $\mathrm{N}$ & $\mathrm{DH}-\mathrm{A}(8)$ & GAR & Bed1 & Kit \\
\hline DH-2 & Add INT GAR & $\mathrm{DH}-\mathrm{A}(8)$ & GAR & Bed2 & Kit \\
\hline DH-3 & $\mathrm{N}$ & $\mathrm{DH}-\mathrm{A}(1)$ & n.a. & CRAWL & Kit, Bed1 \\
\hline DH-5 & $\mathrm{N}$ & $\mathrm{DH}-\mathrm{A}(2)$ & GAR & n.a. & Kit, Bed3 \\
\hline DH-7 & $\mathrm{N}$ & $\mathrm{DH}-\mathrm{B}(5)$ & GAR & Bed3 & Kit \\
\hline DH-8 & $\mathrm{N}$ & $\mathrm{DH}-\mathrm{A}(2)$ & GAR & n.a. & Kit, Bed3 \\
\hline DH-10 & $\mathrm{N}$ & DH-E(8) & GAR & Den & Kit \\
\hline DH-12 & $\mathrm{N}$ & $\mathrm{DH}-\mathrm{F}(4)$ & GAR & Bed4 & Kit \\
\hline DH-19 & Add INT GAR & $\mathrm{DH}-\mathrm{A}(8)$ & GAR & bed2 & kit \\
\hline DH-21 & $\mathrm{N}$ & $\mathrm{DH}-\mathrm{A}(7)$ & n.a. & n.a. & Kit, Bed3 \\
\hline DH-21 & Year Built & $\mathrm{DH}-\mathrm{A}(7)$ & n.a. & n.a. & Kit, Bed3 \\
\hline DH-24 & $\begin{array}{c}\text { Year Built } \\
\text { Delete GAR }\end{array}$ & DH-E(3) & n.a. & n.a. & Kit, Bed1 \\
\hline DH-27 & $\mathrm{N}$ & DH-A(8) & n.a. & Bed1 & Kit \\
\hline DH-32 & $\mathrm{N}$ & DH-A(6) & GAR & n.a. & Kit, Bed3 \\
\hline DH-33 & Year built & $\mathrm{DH}-\mathrm{C}(1)$ & GAR & NA & Kit, Bed2 \\
\hline DH-34 & $\mathrm{N}$ & $\mathrm{DH}-\mathrm{A}(7)$ & n.a. & n.a. & Kit, Bed3 \\
\hline DH-41 & $\mathrm{N}$ & DH-E(1) & n.a. & Hall & kit \\
\hline DH-44 & $\mathrm{N}$ & DH-A(9) & GAR & Bed1 & kit \\
\hline DH-45 & $\mathrm{N}$ & DH-E(3) & GAR & Basement & Kit \\
\hline DH-45 & $\begin{array}{c}\text { Year built } \\
\text { Add INT GAR }\end{array}$ & DH-E(3) & GAR & Basement & Kit, \\
\hline DH-52 & Year built & DH-F(3) & GAR & Basement & Kit \\
\hline DH-56 & $\mathrm{N}$ & DH-D(3) & n.a. & Bed2 & Kitchen \\
\hline
\end{tabular}




\begin{tabular}{|c|c|c|c|c|c|}
\hline \multirow[b]{2}{*}{$\begin{array}{l}\text { House } \\
\text { number }\end{array}$} & \multirow[b]{2}{*}{$\begin{array}{l}\text { PRJ file } \\
\text { modified } \\
\text { (yes/no)? }\end{array}$} & \multirow[b]{2}{*}{$\begin{array}{l}\text { Floor } \\
\text { plan }\end{array}$} & \multicolumn{3}{|c|}{ Source locations } \\
\hline & & & Garage & $\begin{array}{l}\text { Basement/ } \\
\text { crawlspace }\end{array}$ & Interior room(s) \\
\hline DH-60 & $\mathrm{N}$ & $\mathrm{DH}-\mathrm{A}(7)$ & GAR & Basement & Kit \\
\hline DH-60 & $\begin{array}{c}\text { Year Built } \\
\text { Add INT GAR }\end{array}$ & $\mathrm{DH}-\mathrm{A}(7)$ & GAR & Basement & Kit \\
\hline DH-61 & Year built & DH-A(1) & n.a. & Basement & Kit \\
\hline DH-61 & $\mathrm{N}$ & $\mathrm{DH}-\mathrm{A}(1)$ & n.a. & Basement & Kit \\
\hline DH-63 & $\begin{array}{c}\text { Year Built } \\
\text { Delete GAR }\end{array}$ & DH-D(4) & n.a. & Basement & Kit \\
\hline DH-63 & Delete Gar & $\mathrm{DH}-\mathrm{D}(4)$ & n.a. & Basement & Kit \\
\hline DH-64 & $\mathrm{N}$ & $\mathrm{DH}-\mathrm{B}(1)$ & GAR & n.a. & Kit, Bed3 \\
\hline DH-81 & $\mathrm{N}$ & DH-E(4) & n.a. & Basement & Kit \\
\hline MH-1 & $\mathrm{N}$ & MH-B(1) & n.a. & crawl & Kit, Bed1 \\
\hline MH-1 & $\begin{array}{c}\text { Size } \\
\text { Year built }\end{array}$ & NA & n.a. & n.a. & Kit, Bed1 \\
\hline AH-3 & $\mathrm{N}$ & AH-A(2) & n.a. & n.a. & Kit, Bed1 \\
\hline AH-10 & $\mathrm{N}$ & $\begin{array}{l}\text { AH- } \\
\text { C(11) }\end{array}$ & n.a. & Den & Kit \\
\hline AH-34 & Add GAR & AH-E(1) & GAR & Bed3 & Kit \\
\hline AH-21 & $\begin{array}{l}\text { Add INT } \\
\text { GAR }\end{array}$ & AH-D(4) & GAR & Basement & Kit \\
\hline GAR-1 & new & NA & GAR & NA & NA \\
\hline GAR-2 & new & NA & GAR & NA & NA \\
\hline GAR-3 & new & NA & GAR & NA & NA \\
\hline
\end{tabular}

The modifications are described further below:

DH-2: Bedroom 1 in the basement was converted to an integral garage.

DH-19: Bedroom 1 in the basement was converted to an integral garage.

DH-21: Air leakage was modified based on year built and floor area per Table 1 and Equation 1 of Persily et al. (2013) to represent the oldest category of construction (before 1940).

DH-24: Two modifications were made. The side attached garage was deleted and air leakage was modified based on year built and floor area to represent the oldest category of construction (before 1940).

DH33: Air leakage was modified based on year built and floor area to represent the newest category of construction (1990 and newer). 
DH-45: Two modifications were made. Part of the unfinished basement was converted to an integral garage and air leakage was modified based on year built and floor area to represent the newest category of construction (1990 and newer).

DH-52: Air leakage was modified based on year built and floor area to represent the newest category of construction (1990 and newer).

DH-60: Two modifications were made. internal garage added and air leakage was modified based on year built and floor area to represent the second oldest category of construction (1940 to 1969).

DH-61: Air leakage was modified based on year built and floor area to represent the second oldest category of construction (1940 to 1969).

DH-63 (mod1): Two modifications were made. The side attached garage was deleted and air leakage was modified based on year built and floor area to represent the oldest category of construction (before 1940).

DH-63 (mod2): The side attached garage was deleted.

MH-1: MH1 was modified to be smaller with $78 \mathrm{~m}^{2}$ (840 ft2) of floor area with 2 bedrooms, 1 bathroom and a kitchen. The air leakage was modified based on year built and floor area to represent the oldest category of construction (before 1940).

AH-34: The first floor living room was converted to an integral garage.

AH-21: The side attached garage was deleted and part of the unfinished basement was converted to an integral garage.

GAR-1 was created as a new model of a detached garage with a single $32.5 \mathrm{~m}^{2}\left(350 \mathrm{ft}^{2}\right)$ zone and envelope air leakage of $4.81 \mathrm{~cm}^{2} / \mathrm{m}^{2}$ based on the median garage envelope leakage in Table 2 of Emmerich et al. 2003.

GAR-2 was created as a new model of a detached garage with a single $60.4 \mathrm{~m}^{2}\left(650 \mathrm{ft}^{2}\right)$ zone and envelope air leakage of $4.81 \mathrm{~cm}^{2} / \mathrm{m}^{2}$ based on the median garage envelope leakage in Table 2 of Emmerich et al. 2003.

GAR-3 was created as a new model of a detached garage with two zones including a main $60.4 \mathrm{~m}^{2}$ $\left(650 \mathrm{ft}^{2}\right)$ garage zone and a separate $32.5 \mathrm{~m}^{2}\left(350 \mathrm{ft}^{2}\right)$ workroom with envelope air leakage of 4.81 $\mathrm{cm}^{2} / \mathrm{m}^{2}$ based on the median garage envelope leakage in Table 2 of Emmerich et al. 2003. 


\section{Appendix C Analysis of Unmodified Generator X CO Emission Ratio at Reduced $\mathrm{O}_{2}$ vs Ambient}

The shed test data for unmodified Generator X from Figure 9 of NIST Technical Note 1781 (Emmerich et al. 2013) were used to assist in determining an appropriate ratio of the generator CO emission rate at reduced $\mathrm{O}_{2}$ to the $\mathrm{CO}$ emission rate at ambient conditions. Table $\mathrm{C} 1$ shows the $\mathrm{CO}$ emission rate at ambient from the University of Alabama's testing of unmodified Generator X (Tab C of CPSC 2012) and average CO emission rate for all measured data below $18 \% \mathrm{O}_{2}$ for the 6 loading modes. The calculated 6-mode weighted ratio for the generator was 3.0.

Table C1. Unmodified Generator X CO Emission Ratio at Reduced $\mathrm{O}_{2}$

\begin{tabular}{|c|c|c|c|c|}
\hline \multirow{2}{*}{ Mode } & +2 & & \\
\hline & Weighting & $\begin{array}{l}\text { CO emission rate at } \\
\text { ambient (g/h) }\end{array}$ & $\begin{array}{l}\text { CO emission rate } \\
\text { below } 18 \% \mathrm{O}_{2}(\mathrm{~g} / \mathrm{h})\end{array}$ & Ratio \\
\hline 1 & 0.09 & 1000.6 & 3652 & 3.6 \\
\hline 2 & 0.2 & 671.16 & 3395 & 5.0 \\
\hline 3 & 0.29 & 697.54 & 2487 & 3.6 \\
\hline 4 & 0.3 & 1075.6 & 2100 & 1.9 \\
\hline 5 & 0.07 & 971.04 & 1810 & 1.9 \\
\hline 6 & 0.05 & 911.78 & 1623 & 1.8 \\
\hline
\end{tabular}

